Universidade de Brasília - UnB

Faculdade de Direito

Curso de Graduação em Direito

CONTROLE JUDICIAL DE ATOS REGULATÓRIOS

ANANDA TOSTES ISONI

Brasília

2011 
ANANDA TOSTES ISONI

\section{CONTROLE JUDICIAL DE ATOS REGULATÓRIOS}

Monografia apresentada como requisito parcial para a obtenção do grau de bacharel em Direito pela Faculdade de Direito da Universidade de Brasília.

Orientador: Prof. Dr. Luiz Gustavo Kaercher Loureiro 


\section{CONTROLE JUDICIAL DE ATOS REGULATÓRIOS}

Monografia aprovada como requisito parcial para obtenção do grau de bacharel em Direito pela Faculdade de Direito da Universidade de Brasília, pela banca examinadora composta por:

Luiz Gustavo Kaercher Loureiro Prof. Dr. e Orientador

Márcio Pina Marques de Sousa

Procurador-Geral da ANEEL. Espec. e Examinador

Luiz Eduardo Diniz Araujo

Subprocurador-Geral da ANEEL. Me. e Examinador 


\section{AGRADECIMENTOS}

Agradeço primeiramente a Deus, cujo amor incondicional me inspira e me fortalece. Ao Senhor, meu Pai, toda a minha gratidão.

A Nossa Senhora, doce mãe intercessora.

Ao meu amado esposo Ronaldo, que ilumina a minha vida. Com seu companheirismo, tornou mais suave essa caminhada.

Aos meus pais, Edison e Rita, exemplos de integridade, doação e compromisso. Obrigada pelo amor e cuidado de sempre.

Aos meus irmãos e familiares, cujo apoio e compreensão foram fundamentais. Lembro, especialmente, de Anjuli e Evandro, Taila, Dhara e Edison, tão presentes e tão queridos.

Aos meus amigos Ana Luísa, Antonielle, Bárbara, Matheus, Giselle, Juliana, Luciana e Raphaella, pela amizade e incentivo.

Aos colegas e professores da graduação e, particularmente, às grandes amizades que então nasceram e me ensinaram muito mais do que o Direito.

Aos colegas da Procuradoria-Geral da ANEEL, pelas valiosas contribuições e pelo exemplo diário de dedicação e comprometimento.

Ao meu orientador, Professor Gustavo, pela dedicação a este trabalho e ao estudo do Direito Regulatório.

Essa conquista também pertence a vocês. 
Senhor, Tu és nosso Pai, nós somos barro; Tu, nosso oleiro, e nós todos, obra de tuas mãos. Isaías 64,7 


\section{RESUMO}

A autonomia reforçada própria às agências reguladoras torna relevante o estudo do controle de sua atuação. Ao mesmo tempo, suas competências institucionais, voltadas não só à coordenação da atividade econômica regulada, mas também ao equilíbrio dos interesses públicos e privados envolvidos, exigem que as formas tradicionais de controle sejam revistas. Nesta monografia, adotou-se como objeto de pesquisa o controle judicial dos atos regulatórios.

A partir de um panorama atual, buscou-se apontar deficiências e contradições observadas na realização dessa modalidade de controle. Por meio da análise de dados levantados em pesquisas, constatou-se que o Poder Judiciário além de decidir em tempo incompatível com as transformações de mercado, o faz com pouca qualidade técnica e de forma imprevisível, em detrimento da segurança jurídica e da estabilidade da atividade regulatória, tão caros às agências. Pontuouse, ainda, que os efeitos da revisão judicial de um ato regulatório podem afetar não só os integrantes da relação processual, mas também se desdobrar sobre a pluralidade de interesses tutelados pelas agências reguladoras.

Nessa linha, pretendeu-se investigar os limites da revisão judicial de atos regulatórios e, particularmente, se o controle de legalidade seria suficiente para torná-la efetiva. Para tanto, desconstruiu-se o dogma da discricionariedade técnica das agências reguladoras e concluiu-se que a análise de mérito desses atos não somente é possível, como também é fundamental à efetividade do controle judicial. Além disso, questionou-se se caberia ao Poder Judiciário decidir de forma substitutiva às agências reguladoras. A esse respeito, concluiu-se que a amplitude do exame judicial não autoriza a substituição do agente regulador pelo juiz, que poderá, contudo, definir prazo para que as agências decidam.

Por fim, foram propostas soluções procedimentais e estruturais, com vistas ao aprimoramento do controle judicial de conteúdo dos atos regulatórios. Nesse contexto, ressaltou-se a relevância da atuação de agências reguladoras em processos que, ao colocar em questão a validade de seus atos, possam repercutir no equilíbrio regulatório. Entre as formas de intervenção processual de tais entidades, estudou-se sua participação como amicus curiae, litisconsorte e assistente. Ademais, considerando a possibilidade de "captura" dos agentes reguladores, também se apontaram soluções que independem de sua atuação. 
Assim, destacou-se a importância do papel desempenhado pelo perito judicial e a possibilidade de realização de audiências públicas judiciais. Sugeriu-se, ainda, a criação de varas especializadas em matéria regulatória, bem como foram mencionadas vantagens e desvantagens de sua implementação.

Palavras-chaves: agências reguladoras; Poder Judiciário; controle judicial de atos regulatórios; discricionariedade técnica; controle de legalidade; controle de mérito; equilíbrio regulatório. 


\section{ABSTRACT}

The enhanced autonomy of regulatory agencies demands a more accurate study of the control of their performance. At the same time, their institutional powers, not only directed to the coordination of the regulated economic activity, but also to the balance of public and private interests involved, require traditional forms of control to be reviewed. In this monograph, the subject of the research was restricted to the judicial control of regulatory acts.

Starting from the current panorama, it was intended to point out contradictions and deficiencies observed in carrying out this type of control. Through the analysis of data collected in empirical surveys, it was found that Judiciary decisions are not only rendered in times not compatible with the market changes, but also technically poor and not uniform, all that to the detriment of the regulatory expediency, certainty and stability, values highly regarded by agencies and regulated agents. It was pointed out also that the effects of judicial review of a regulatory act may affect not only the members of the procedural relation, but also unfold on the plurality of interests protected by regulatory agencies.

In this line, the intention was to investigate the boundaries of judicial review of regulatory acts, and, particularly, to ascertain if the control of legality was enough to make this review effective. To this end, the dogma of the technical discretion of the regulatory agencies was deconstructed, leaving room to the conclusion that a review on the merits of these acts is not only possible, but is the key to the effectiveness of judicial review. In addition, it was questioned whether judicial decisions should replace agencies' decisions. In this respect, it was concluded that the extent of judicial review does not authorize the replacement of a regulator by the judge, who may, however, set deadline for agencies to decide.

Finally, some structural and procedural solutions have been proposed, in order to improve the judicial control of the merit of regulatory acts. In this context, it was emphasized the relevance of the action of regulatory agencies in cases that, by questioning the validity of their acts, impacting the regulatory balance. Among the procedural forms of intervention of such entities, it was studied their participation as amicus curiae, litisconsorte and assistant. Furthermore, considering the possibility of "capture" of regulators, it was also pointed out solutions that are independent of their performance. Thus, it was emphasized the importance of the role of expert witness 
and the possibility of judicial public hearings. It was suggested also the creation of specialized courts on regulatory and advantages and disadvantages of its implementation were mentioned.

Key words: regulatory agencies; Judiciary; judicial control of regulatory acts; technical discretion; control of legality; control of the merit; regulatory balance. 


\section{SUMÁRIO}

INTRODUÇÃO

CAPÍTULO 1 - O ESTADO REGULADOR E A LEGITIMIDADE DEMOCRÁTICA

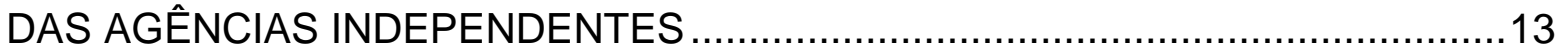

1.1. Regulação de atividades econômicas e agências reguladoras..................13

1.2. Legitimidade democrática e necessidade de controle .............................18

CAPÍTULO 2 - AGÊNCIAS REGULADORAS E PODER JUDICIÁRIO ....................27

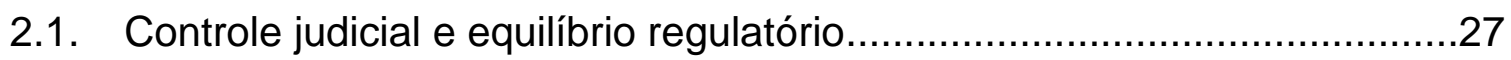

2.2. Panorama do controle judicial de atos regulatórios no Brasil.....................28

2.2.1. Dados levantados pela Associação Brasileira de Infraestrutura e Indústrias

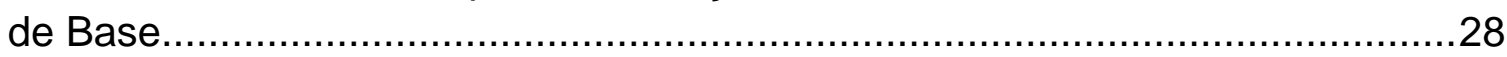

2.2.2. Dados levantados pela Universidade de São Paulo.....................................30

2.2.3. Segurança jurídica e equilíbrio regulatório .................................................34

CAPÍTULO 3 - LIMITES DO CONTROLE JUDICIAL DE ATOS REGULATÓRIOS .41

3.1. Controle de legalidade e controle de mérito............................................41

3.2. O dogma da discricionariedade técnica das agências reguladoras ..........50

3.3. Substituição de atos regulatórios por decisões judiciais ..........................56

CAPÍTULO 4 - APRIMORAMENTO DO CONTROLE JUDICIAL DE ATOS

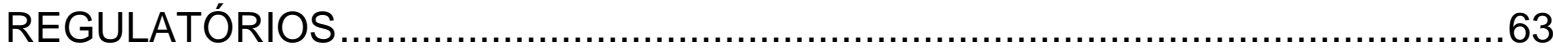

4.1. Participação de agências reguladoras em processos judiciais .................64

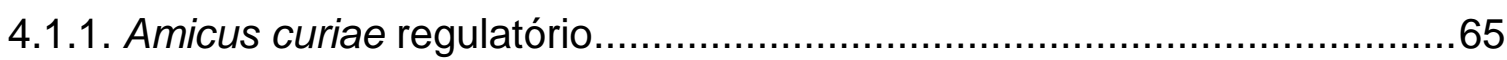

4.1.2. Litisconsórcio e assistência processual ................................................72

4.2. Instrumentos e propostas para um controle de conteúdo dos atos

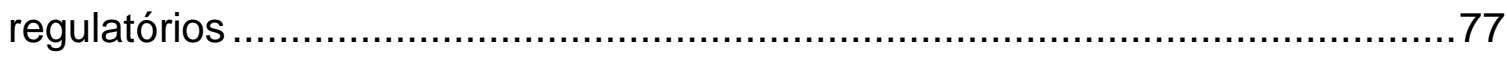

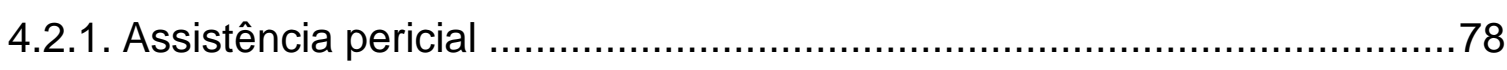

4.2.2. Realização de audiências públicas .................................................... 79

4.2.3. Criação de varas especializadas em matérias regulatórias .......................83

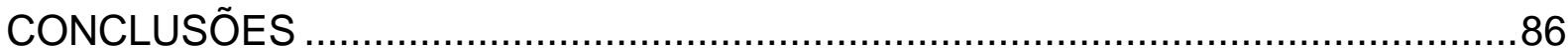

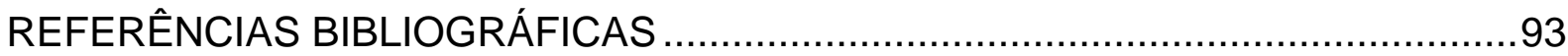

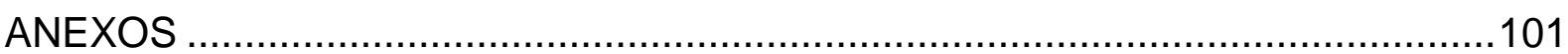




\section{INTRODUÇÃO}

A derrocada do Estado empresário foi sucedida pelo advento de entidades independentes ou, nas palavras de ARAGÃO (2009), dotadas de autonomia reforçada ${ }^{1}$ em relação à Administração Pública central. Responsáveis pela regulação de atividades econômicas antes desempenhadas diretamente pelo Estado, as agências reguladoras independentes acumularam funções relativas aos Poderes Executivo, Legislativo e Judiciário. Seu elevado grau de autonomia torna relevante o estudo sobre as formas de controle de sua atuação.

Neste trabalho, optou-se por investigar o controle judicial de atos regulatórios. Para além das atribuições das agências reguladoras relativas à edição de normas gerais e abstratas, também se pode cogitar de sua competência para formular normas individuais e concretas, destinadas a disciplinar situações fáticas determinadas (JUSTEN FILHO, 2002, p. 541). Nesse contexto, para os fins visados nesta monografia, o conceito de ato regulatório compreenderá atos normativos de efeitos abstratos e concretos.

No que tange ao controle judicial da atividade regulatória, nota-se ser insuficiente aludir-se ao princípio da universalidade de jurisdição. Conquanto a inafastabilidade do Judiciário seja pressuposto inevitável para esta análise, dadas as particularidades do modelo regulador, assume especial relevância o estudo dos desdobramentos e limites desse controle.

Para tanto, no primeiro capítulo, serão introduzidos conceitos relevantes para o desenvolvimento desta pesquisa. Nesse passo inicial, serão trabalhadas noções relacionadas à regulação, à legitimidade democrática das agências reguladoras e à necessidade de controle de seus atos.

No segundo capítulo, o enfoque será a relação travada entre agências reguladoras e o Poder Judiciário. A partir do exame de dados obtidos por meio de pesquisas de campo e de posicionamentos doutrinários a respeito do assunto, será analisado em que medida a revisão judicial interfere ou pode interferir no equilíbrio regulatório.

\footnotetext{
${ }^{1}$ Segundo ARAGÃO (2009, p. 15), a nomenclatura "independente" é apenas um meio de denotar a sua autonomia reforçada, que é, todavia, como toda autonomia, limitada por definição. Apesar disso, o autor destaca não ser imprópria à utilização do termo "independente", que as distingue da maioria das entidades da Administração Indireta, cuja autonomia é mais nominal do que material.
} 
O estudo de tais resultados é importante porque, notadamente quando se trata de setores regulados, a segurança jurídica é fundamental ao aporte e incremento de investimentos no país. Ademais, a relevância de se garantir a estabilidade do ambiente regulado não se refere tão somente ao equilíbrio econômico-financeiro dos contratos firmados com as concessionárias de serviço público. Compete às agências reguladoras a tutela de interesses difusos enredados na sua atividade. Desse modo, a pesquisa das interações entre o Judiciário e as agências reguladoras tem por escopo, ainda, examinar em que proporção o controle judicial de atos regulatórios pode colocar em risco a garantia do pluralismo e do equilíbrio entre valores contrapostos e entre os interesses dos mercados e os fins de serviços públicos (MAS, 1999, p. 69).

No terceiro capítulo, será analisada a extensão do controle judicial de atos regulatórios. Com esse objetivo, a partir de pesquisa doutrinária e jurisprudencial, argumentos que restringem esse controle a um exame de legalidade serão contrapostos à defesa de um controle de mérito, bem como será enfrentado o dogma da discricionariedade técnica das agências reguladoras. Ainda quanto aos limites do controle judicial, merecerá especial atenção a análise da possibilidade de substituição de atos regulatórios por decisões judiciais.

Por fim, no quarto capítulo serão apresentadas propostas procedimentais e estruturais com vistas ao aprimoramento do controle de conteúdo de atos regulatórios pelo Poder Judiciário.

Não será possível, em face dos limites deste trabalho, tratar dos efeitos de decisões judiciais e, tampouco, dispor sobre parâmetros objetivos a serem observados pelo Judiciário na realização desse controle. O estudo de tais temas poderá ser desenvolvido em pesquisas futuras, a partir das reflexões a serem propostas ao longo desta monografia.

Em síntese, este trabalho privilegiará a problematização dos limites do controle judicial de mérito de atos regulatórios, sem descurar da importância do equilíbrio do setor regulado. Por meio de uma perspectiva crítica, pretende-se questionar argumentos recorrentemente adotados como premissas pela doutrina e pelos órgãos judiciários - verdadeiros "lugares comuns" quando se trata do controle judicial de tais atos. 


\section{O ESTADO REGULADOR E A LEGITIMIDADE DEMOCRÁtICA DAS AGÊNCIAS INDEPENDENTES}

\subsection{Regulação de atividades econômicas e agências reguladoras}

São múltiplos os sentidos atribuídos ao vocábulo "regulação"2. Todavia, é possível definir como elemento comum aos conceitos propostos a restrição a escolhas privadas pela imposição de regras públicas (EBERLEIN apud CUÉLLAR, 2008, p. 13).

Embora a regulação possa incidir sobre qualquer objeto social, como a família, a educação, a saúde, o trabalho, é no âmbito da economia estatal que ele vem sendo utilizado mais frequentemente no direito brasileiro. Com efeito, é no âmbito do direito econômico (ou direito administrativo econômico) que o tema vem sendo abordado com maior profundidade. Nesse contexto, torna-se relevante tratar da definição de regulação econômica (DI PIETRO, 2003).

Segundo CUÉLLAR, a regulação econômica deve ser entendida como um condicionamento externo à atividade dos agentes econômicos, abrangendo as vertentes da regulamentação, supervisão e sancionamento (2008, p. 13). Se, por um lado, é certo que tal modalidade de regulação tem por objeto atividades econômicas privadas, por outro, as finalidades da regulação econômica não são consenso na doutrina.

Embora seja usual que doutrinadores apontem a regulação estatal como instrumento para suprir as deficiências do mercado, JUSTEN FILHO (2002, p. 31) anota que essa visão tem sido alterada, especialmente a partir da segunda metade do século XX. Pode-se dizer que a alteração consistiu muito mais em uma ampliação da dimensão da regulação do que em uma revisão essencial das concepções essenciais.

O autor identifica essa intensa revisão de concepções mais antigas como uma segunda onda intervencionista, que denominou regulação econômica social. Sob a nova perspectiva, a regulação consistiria na atividade estatal de intervenção indireta sobre a conduta dos sujeitos públicos e privados, de modo permanente e

\footnotetext{
${ }^{2}$ Sobre o tema, confira-se DI PIETRO, 2003, p. 27 e 28.
} 
sistemático, para implementar as políticas de governo e a realização dos direitos fundamentais (JUSTEN FILHO, 2005, p. 447).

De fato, embora a atividade regulatória vise à obtenção de eficiência econômica, a tanto não pode ser limitada. As finalidades regulatórias também se relacionam à realização de valores fundamentais consagrados pela sociedade, sejam eles de natureza econômica ou não (JUSTEN FILHO, 2002, p. 40). Nessa linha, cita-se o conceito proposto por ARANHA e LOUREIRO (2009), segundo o qual regulação é a reconfiguração conjuntural do ambiente regulado voltada à consecução de um modelo ideal de funcionamento do sistema e dirigida por regras e princípios inscritos e espelhados nos direitos fundamentais.

O Estado pode regular a atividade econômica diretamente, por órgãos da Administração Pública direta, ou indiretamente, por meio de entes dotados de parcial ou total independência. A regulação por meio de entidades independentes, ou regulação independente, originou-se nos Estados Unidos, com a criação da Interstate Commerce Commission, em 1887, para regulamentar os serviços interestaduais de transportes (ARAGÃO, 2009, p. 229).

Por influência do direito norte-americano, a regulação por meio de entes reguladores independentes foi aos poucos sendo introduzida nos ordenamentos jurídicos de outros países, dentre os quais se inclui o Brasil (CUÉLLAR, 2008, p. 14).

Para MAJONE (2006), o insucesso da atuação do Estado empresário explica a mudança para um modo alternativo de controle no qual os serviços públicos e outros setores, considerados importantes por afetar o interesse público, são deixados em mãos privadas, mas sujeitos a normas elaboradas e aplicadas por agências especializadas ${ }^{3}$. Por seu turno, MOREIRA (1997b, p. 30 e 31), citando BREUER, considera o surgimento de órgãos e entidades públicas autônomas em relação à Administração Pública central como a resposta necessária do moderno Estado social ao alargamento das suas tarefas. A autonomização de organismos

\footnotetext{
${ }^{3}$ Nessa linha, MAJONE (2006, p. 14-15) sustenta que a maioria das diferenças estruturais entre o Estado positivo (intervencionista) e o Estado regulador podem ser examinadas, retrospectivamente, quanto à distinção entre duas fontes de poder governamental: a tributação (ou tomar fundos emprestados) e a despesa, de um lado; e a criação de regras do outro. Segundo o autor, esta é uma distinção entre políticas que exigem o dispêndio direto de recursos públicos e as políticas regulatórias. $O$ ponto crucial é que as limitações orçamentárias têm impacto muito reduzido sobre a elaboração de regras, enquanto o tamanho de programas de despesa direta não-regulatórios é determinado por dotações orçamentárias e, assim, pelo nível de receitas tributárias do governo. $O$ orçamento público é uma limitação leve que se impõe aos formuladores de normas, porque o custo real dos programas reguladores não é absorvido pelos reguladores, mas por aqueles que têm de obedecer à regulação.
} 
administrativos seria, nesse sentido, uma conseqüência, em termos de diferenciação e especialização, da ampliação e diversificação das tarefas administrativas.

De acordo com MOREIRA (1997a, p. 36-37), um processo de regulação implica tipicamente as seguintes fases: formulação das orientações da regulação; definição e operacionalização das regras; implementação e aplicação das regras; sancionamento dos transgressores; decisão dos recursos.

Tais fases podem ser agrupadas em três etapas essenciais:

(a)a aprovação das normas pertinentes (leis, regulamentos, códigos de conduta, etc.); (b) implementação concreta das referidas regras (autorizações, licenças, injunções, etc.); (c) fiscalização do cumprimento e punição das infrações.

Nesse prisma, a regulação e, assim, as entidades reguladoras independentes, podem conjugar três tipos de poderes correlatos aos poderes típicos do Estado - um poder normativo, um poder executivo e um poder parajudicial.

Com efeito, o desenvolvimento de uma administração independente, que possui poderes decisórios regulamentares e individuais, necessita de um espaço administrativo suficientemente 'aberto'. Não há qualquer possibilidade (teórica ou prática) destas instituições se desenvolverem em espaços administrativos 'fechados', organizados e controlados de maneira rígida (MODERNE apud ARAGÃO, p. 215).

Assim é que o advento das autoridades reguladoras independentes alterou o modelo clássico da Administração Pública, baseado nos princípios da unidade, do centralismo, da hierarquia e da autoridade, e na separação entre o público e o privado. Nessa esteira, passaram a vingar os princípios da diferenciação e da diversidade, da descentralização, da autonomia, das parcerias entre o público e o privado, bem como a contratualização e a lógica do mercado (MARQUES e MOREIRA, 1998/1999, p. 150-151).

No Brasil, todas as agências reguladoras independentes foram qualificadas institucionalmente por suas respectivas leis instituidoras como autarquias especiais (DI PIETRO, 1999, p. 387) ${ }^{4}$. Segundo BARROSO (2002, p.

\footnotetext{
${ }^{4}$ Não se ignora, contudo, que no Brasil, antes do movimento de privatização da década de 90 , já existiam órgãos e entidades encarregados do exercício da atividade de planejamento e fiscalização das atividades particulares e púbicas realizadas mediante delegação ou outorga. De fato, entidades como o Banco Central (BACEN), Conselho Monetário Nacional (CMN), a Comissão de Valores Mobiliários (CVM) não são instituições recentes no Estado Brasileiro. Nas palavras de CARVALHO (2008, P. 844), buscam assegurar a estabilidade da moeda, do mercado e das atividades comerciais das sociedades, com maior ou menor efetividade nos resultados alcançados, sem qualquer dependência com o movimento de desestatização realizado
} 
121), tal definição se deve ao fato de serem dotadas de um conjunto de privilégios específicos que a lei lhes outorgou, tendo em vista a consecução de seus fins. Para o autor, a pedra de toque desse regime especial das agências reguladoras é a sua independência em relação à Administração Pública central. Para que não fracasse o ambicioso projeto nacional de melhoria dos serviços públicos, o espaço de legítima discricionariedade das agências deve ser preservado de ingerências estranhas às exigências regulatórias de equilíbrio e garantia de direitos fundamentais.

Apesar dos diferentes posicionamentos doutrinários a respeito do assunto, observa-se que o poder normativo das agências reguladoras em regra é apontado como uma de suas características preponderantes. Para MENDES (2000, p. 129), a competência normativa é o critério que de fato denota a independência das agências reguladoras. Nessa linha, o autor sustenta:

Assim, escolhemos como um outro critério a competência normativa, entendendo-se por esta a produção de normas gerais, que podem ser veiculadas através de regulamentos (e, nesse caso, se fala em poder regulamentar), resoluções, portarias, etc.

Possuindo poder normativo, então, consideramos o ente uma agência reguladora. Esta será, portanto, não 0 ente que simplesmente exerça regulação em qualquer de suas formas, mas, acima de tudo, o que possua competência para produzir normas gerais e abstratas que interferem diretamente na esfera de direitos do particular.

De fato, a necessidade de imposição de normas para o desenvolvimento de determinado setor econômico, marcado pela velocidade de desenvolvimento tecnológico e pela complexidade da sociedade civil, relaciona-se à atribuição de tal poder às agências. Supre-se, assim, a insuficiência legiferante do Congresso Nacional sobre a amplitude de matérias técnicas, peculiares aos diversos setores, em velocidade compatível com o tempo concorrencial. Disso decorre uma tendência a que a lei se limite a fixar parâmetros extremamente abertos, podendo em muitos casos vir a operar na prática uma verdadeira delegação de competência legislativa em favor das agências (JUST, 2009).

Segundo MARQUES NETO (2000, p. 79-80), a cada dia, em grande medida como conseqüência da evolução tecnológica, observa-se: i) o aparecimento de novos setores a clamar pautas normativas; ii) a complexização das questões

principalmente na década de 90. Não obstante, faz-se coro ao entendimento de ARAGÃO (2009), para quem nenhuma de tais entidades tinha ou tem o perfil de independência frente ao Poder Executivo afirmado pelas recentes leis criadoras das agências reguladoras e pela jurisprudência do Supremo Tribunal Federal - STF. 
merecedoras de regulamentação e, por tabela, a necessidade de mais intrincados e específicos instrumentos normativos; iii) a notável separação entre os diversos campos do Direito, pautada pela edificação de princípios e conceitos próprios a cada setor e não facilmente aproveitáveis para os demais. Todos esses fatores indicam a dificuldade de se sustentar que a lei seja instrumento exclusivo da ação regulatória e fonte única do arcabouço regulamentar.

CHEVALLIER (apud JUST, 2009) aponta a eclosão da regulação como um sintoma da ruína do modelo monolítico próprio do Estado moderno, caracterizado pela unidade e pela hierarquia das fontes de produção normativa (policentrismo normativo). Na mesma linha, MARQUES NETO (2002, p. 206-207) sustenta que a atuação dos órgãos reguladores está atrelada à crise vivida pelo princípio da legalidade, que não decorre tão-somente do advento das agências reguladoras, mas da própria profusão de fontes normativas.

Com efeito, à medida que se coloca inerente ao órgão regulador o exercício de uma forte atividade regulamentadora, relacionada com as especificidades e complexidades próprias ao âmbito de sua regulação, advém a incompatibilidade desta atividade com o pressuposto de vinculação estrita da atividade administrativa à lei ${ }^{5}$. Segundo MARQUES NETO (2002, p. 207), tal incompatibilidade decorre, justamente, do caráter de mediação e de articulação que os órgãos reguladores cumprem em face dos diversos interesses públicos ${ }^{6}$ enredados em sua atividade.

JUST (2009) destaca que a regulação não se restringe à simples produção de normas gerais. Segundo o autor, sua noção central é, sem dúvida, a do disciplinamento jurídico. Mas somente seria possível compreender o seu sentido específico, no contexto atual, ao se entender que o recuo do papel do Estado como produtor direto de bens e serviços não pretendeu significar o seu desengajamento.

\footnotetext{
${ }^{5}$ Tal vinculação se expressa na fórmula do princípio da legalidade da Administração, segundo o qual a Administração só pode fazer o que a lei autoriza.

${ }^{6}$ A utilização do termo no plural, pelo autor, não é acidental. O paradigma segundo o qual o interesse público se contrapõe aos interesses privados, motivo pelo qual deve predominar sobre estes, tem raízes históricas. 0 individualismo renascentista, que pregava a prevalência dos interesses privados, parece haver ensejado, à época seguinte, o entendimento de que a negação desses interesses significaria alcançar o interesse comum. Assim, adotou-se de modo generalizado o pressuposto do interesse público como uno, exclusivo, singular, que em cada situação concorre com os interesses privados. Para MARQUES NETO (2002, p. 82), trata-se de premissa de oposição, de embate, de afirmação pela negação, segundo o qual a consagração do interesse público se oporia essencialmente aos interesses privados e, destarte, somente se efetivaria a partir de algum sacrifício ou restrição de interesses dos particulares.
} 
De outro modo, pelo menos idealmente, como contrapartida ao recuo do Estado empresário, a regulação correspondeu à "invenção" de uma nova função, estratégica sem ser planificadora, que consiste em fixar as regras do jogo, mas em fixá-las não à distância, e sim em resposta imediata aos estímulos vindos da atividade regulada e interagindo com eles. Em outros termos, a regulação seria uma espécie de intervenção disciplinadora.

Segundo JUST (2009), é indiscutível a dificuldade de harmonizar esse processo com os dogmas organizadores e, sobretudo, legitimadores do Estado constitucional, que nunca renegou a idéia fundamental de primazia da lei como expressão da vontade popular.

\subsection{Legitimidade democrática e necessidade de controle}

A larga atuação das agências reguladoras, que assumem funções tipicamente relacionadas aos poderes Executivo, Legislativo e Judiciário, tem suscitado questionamentos quanto à sua legitimidade. Nas palavras de MATTOS (2006, p. 339), a questão é saber em que medida pode ser legítima e democrática a decisão sobre o conteúdo da regulação por um órgão colegiado não-eleito e com autonomia decisória em relação à administração direta. Ou seja, questiona-se a existência de um déficit democrático ${ }^{7}$ na atuação das agências reguladoras ${ }^{8}$.

Entre os entendimentos esposados pela doutrina, citam-se três linhas de trabalhos, a partir de seleção apontada por MATTOS (2006, p. 338 a 342).

Em um primeiro grupo de autores estão aqueles que refutam o atual modelo regulatório. Entre os argumentos expendidos está o de que o poder que as agências detêm para especificar o conteúdo das normas gerais previstas em lei ou

\footnotetext{
${ }^{7}$ A expressão tornou-se conhecida ao ser utilizada por David Marquand, que apontou, em 1979, a deficiência na forma de indicação dos membros do Parlamento Europeu, os quais eram (à época) indicados indiretamente pelos parlamentos nacionais. Pretendia-se que a solução importasse na adoção de sistema de eleição direta. A questão específica foi superada pelas novas regras atinentes à eleição dos membros do Parlamento Europeu, mas a expressão sobreviveu e ganhou generalização. Passou a aludir-se, de modo amplo, ao déficit democrático da União Européia visando a indicar não apenas a ausência de mecanismos de participação direta do cidadão na formação da vontade política, mas também a inaplicação das concepções clássicas de tripartição de poderes à organização comunitária européia. (MÉNY apud JUSTEN FILHO, 2006, p. 301)

${ }^{8}$ JUSTEN FILHO (2006, p. 302) assinala que a mera proposição sobre a existência de um déficit democrático na atuação das agências reguladoras já evidencia, sob um certo ângulo, uma tomada de posição sobre a questão, uma vez que o termo déficit denota insuficiência. De fato, o questionamento acerca do déficit de legitimidade democrática das agências reguladoras parte da premissa de que sua atuação deva se concretizar por meio de vias democráticas.
} 
em decretos do presidente seria inconstitucional por não haver previsão constitucional para tanto.

Para DI PIETRO (apud MATTOS, 2006, p. 340), que integraria o grupo, a atuação das agências reguladoras ensejaria um déficit de controle de legalidade por parte do Poder Judiciário, tendo em vista que haveria a necessidade de recorrer, com maior frequência, ao princípio da razoabilidade das normas reguladas em face da intenção do legislador, para a decisão de sua constitucionalidade. Haveria, por conseguinte, perda de segurança jurídica ou de legitimidade democrática, uma vez que as normas formuladas pelas agências se distanciariam das políticas públicas definidas em lei ou em regulamento expedido pelo chefe do Poder Executivo para um dado setor da economia.

Desse modo, essa primeira linha de estudos, aponta a existência de um déficit democrático na atuação das agências reguladoras, notadamente quanto à sua função normativa, mas reduz a legitimação democrática à via da eleição popular. Como se defenderá mais adiante, uma vez que a legitimação democrática pode se concretizar por diversos meios, entende-se que tal entendimento reflete uma concepção limitada, insuficiente e inadequada sobre o próprio conceito de Democracia (JUSTEN FILHO, 2006, p. 308).

Ainda quanto aos autores que contestam o modelo atual, mas em uma perspectiva mais restrita à existência das agências reguladoras, estão aqueles que afirmam que seu poder normativo não existiria ou não deveria existir. Nesse prisma, a atuação normativa das agências reguladoras significaria uma delegação abdicatória, ou, em outros termos, uma renúncia do Poder Legislativo ao exercício de competência fixada pela Constituição ${ }^{9} \mathrm{e}$, portanto, seria inconstitucional.

Esse argumento está amparado em uma visão clássica do princípio da separação de Poderes. Contudo, como observado por SILVA (2004, p. 113), hoje o princípio não configura aquela rigidez de outrora. A amplitude das atividades do Estado contemporâneo impôs nova visão da teoria da separação de poderes e novas formas de relacionamentos entre os órgãos legislativos e executivo e destes com o judiciário. Além disso, embora extrapole os limites do presente trabalho avançar na questão, é importante anotar que a função normativa não se confunde

\footnotetext{
${ }^{9}$ No ponto, MATTOS (2006, p. 340, nota n. 18) refere-se à obra Regulamento e Princípio da Legalidade, Revista de Direito Público (RDP), n. 96, p. 42, out.-dez. 1990, de Celso Antônio Bandeira de Mello.
} 
com a legislativa, embora com ela se relacione (ALESSI apud GRAU, 2000, p. 178180).

Uma segunda linha de trabalhos almeja a imprimir novo sentido à irrenunciabilidade do poder-dever de legislar (MATTOS, 2006, p. 340). Nesse sentido, busca-se justificar a função normativa das agências reguladoras como autêntica delegação complementar (não abdicatória) que surge, no plano dos fatos, da necessidade de lidar com a complexidade social e econômica em termos de técnicas de saberes especializados. Assim, o fundamento constitucional de tais delegações seria a introdução do princípio da eficiência no artigo 37 da Constituição Federal. Em outros termos, o aludido princípio exigiria que a Administração, em vista do mercado, [fosse] dotada de competências reguladoras de natureza técnica e especializada sob pena de paralisia. (FERRAZ JÚNIOR, 2008)

Essa construção argumentativa conduz, no limite, ao entendimento de que as agências reguladoras não sofreriam um déficit democrático porque sua legitimação derivaria não de sua abertura à sociedade, mas da eficiência de sua atuação. Segundo JUSTEN FILHO (2002, p. 380), essa é uma abordagem perigosa do instituto das agências. Para o autor, está subjacente a esse enfoque a tese de que a soberania popular poderia ser substituída pela eficiência governativa ${ }^{10}$. Assim, Democracia e agências reguladoras, no máximo, se complementariam, tendo em vista a afirmação da Democracia no âmbito de outras instituições estatais. (JUSTEN FILHO, 2006, p. 320-321).

Ademais, tal concepção é insuficiente, dado que se ampara na natureza técnico-científica das decisões regulatórias, supostamente neutras, e, assim, no conceito de discricionariedade técnica, rechaçado por significativa parcela da doutrina, conforme se demonstrará posteriormente.

\footnotetext{
${ }^{10}$ Segundo JUSTEN FILHO (2002, p. 380): A proposta de legitimação pela eficiência é uma versão atualizada de propostas políticas autoritárias, que tiveram grande prestígio já alguns decênios. Mesmo no Brasil, o grande argumento a favor da legitimação dos governos militares foi a produção do milagre econômico. A supressão das liberdades era justificada como o preço a pagar pela eficiência econômica. A falsidade do argumento se revelou evidente em todos os casos, nos mais diversos países. Mais do que isso, a proposta de legitimação pela eficiência foi responsável por enormes tragédias políticas e por crimes contra a Humanidade. No mesmo sentido, MATTOS (2006, p. 359) problematiza o argumento: De onde teria vindo, então, a legitimidade do conteúdo das políticas públicas editadas nessas condições? Tal legitimidade não teria se constituído democraticamente e, conforme já observei no capítulo 3, pode decorrer dos efeitos substantivos (enquanto eficiência econômica gerada) das políticas econômicas sobre a sociedade. É o que explicaria, por exemplo, o apoio às políticas econômicas dos governos ditatoriais e a suas políticas nacional-desenvolvimentistas, que geraram crescimento econômico, difundiram publicamente a imagem do "Brasil Potência", mas se mostraram depois processos profundamente desiguais de monopolização do capital por determinados grupos de interesse.
} 
Há, ainda, uma terceira linha de estudos que se funda na premissa de que deva haver uma regulação técnica de mercados. Para esses autores, tal necessidade teria suscitado o rompimento da organização de poderes do constitucionalismo clássico e a concentração do exercício de tal função regulatória no Poder Executivo ${ }^{11}$.

Segundo MATTOS (2006, p. 341), apesar de considerarem em seus argumentos os mecanismos de participação ou controle social, a maior parte desses trabalhos enfatiza com maior intensidade os aspectos de legitimidade pela eficiência, incorrendo no mesmo entendimento esposado pela segunda linha. Desse modo, estaria relegada a segundo plano a reflexão acerca do sentido e funcionamento dos mecanismos de participação pública no processo de formulação do conteúdo da regulação, enquanto legitimação das normas editadas e das decisões tomadas dentro desse novo locus de poder constituído pelas agências reguladoras independentes.

Nesse contexto, MATTOS salienta que o modelo analítico representado por tais linhas de estudos estaria preso a uma concepção teórica de separação de poderes própria de um modelo de Democracia e de direito liberais, insuficiente em face da complexidade das relações sociais inerentes ao Estado regulador.

Para além das três linhas de trabalhos apontadas por MATTOS, observase, ainda, a existência de corrente doutrinária que defende que a submissão do exercício do poder decisório a um estrito procedimento geraria efeitos de legitimação semelhantes aos derivados do processo eleitoral. A denominada legitimidade pelo procedimento deve ser compreendida com ressalvas em razão de sua indissociável vinculação à organização da União Européia. Por esse prisma, é importante ressaltar que a organização comunitária européia ancora-se em pressupostos políticos específicos, o que acarreta a disputa sobre déficit democrático. A esse respeito, JUSTEN FILHO (2006, p. 326) propõe a seguinte reflexão:

Sob um certo ângulo, a invocação à legitimação pelo procedimento é a única alternativa para a União Européia (ao menos, no atual modelo). Lembre-se que o único órgão comunitário cujos membros são eleitos é o Parlamento Europeu, o qual não dispõe de competências legiferantes próprias da teoria da tripartição dos poderes. Os outros órgãos políticos fundamentais (Conselho e Comissão) acumulam competências legiferantes e administrativas.

\footnotetext{
${ }^{11}$ Entre os autores apontados por MATTOS (2006, p. 341, nota 20) citem-se Fernando Herren AGUILLAR, Carlos Ari SUNDFELD e Alexandre Santos de ARAGÃO.
} 
Daí se segue que os conceitos da Democracia clássica apenas podem ser aplicados de modo marginal no âmbito da União Européia.

Diversamente se passa quanto aos Estados ocidentais (inclusive o Brasil), em que a legitimação pelas vias clássicas é perfeitamente possível. Por isso, a estrita observância de procedimentos pode ser reputada como uma exigência necessária ao desempenho de qualquer competência estatal. Mas não há impedimento à adoção de outros mecanismos destinados a assegurar a natureza democrática da atuação da instituição.

Desse modo, entende-se que há ainda outras vias de legitimação para as agências independentes brasileiras, para além da via procedimental. Entre elas, encontram-se algumas alternativas de cunho democrático (JUSTEN FILHO, 2006).

Em estudo que investiga a existência de um déficit democrático na regulação independente, JUSTEN FILHO (2006, p. 304) aponta para a ausência de um modelo único ou padronizado de Democracia. Para tanto, o autor traz à baila precedente da Corte Européia dos Direitos Humanos, segundo o qual embora seja necessário subordinar os interesses dos indivíduos àqueles de um grupo, a Democracia não se restringe à supremacia constante da opinião de uma maioria; ela impõe um equilíbrio que assegure às minorias um tratamento justo e que evite todo abuso de uma posição dominante ${ }^{12}$.

Disso resulta que inexiste um modelo único de regime democrático apto a assegurar o equilíbrio entre a preponderância da vontade da maioria e a realização dos princípios fundamentais. Nessa linha, nenhum modelo concreto é definitivo, perfeito e acabado, de modo que, tal qual sustentado anteriormente, a legitimação democrática não se concebe exclusivamente pela via da eleição popular.

Por outro lado, isso não significa a inexistência de elementos comuns aos diversos modelos de Democracia. Segundo JUSTEN FILHO (2006, p. 308), o núcleo da noção de Democracia, relaciona-se à existência de (a) mandatos eletivos temporários para os cargos políticos de maior relevância e de (b) instrumentos de garantia e controle do exercício do poder, destinados a assegurar tanto a referibilidade das decisões à vontade popular como a realização dos princípios e valores fundamentais. Esse modo de organização do poder político estatal se justifica tendo em vista uma limitação interna de competências, de modo a evitar

\footnotetext{
12 Caso Young, James e Webster, decidido em 13 de agosto de 1981 (confira-se em WACHSMANN, Patrick. Libertes Publiques. 3. ed. Paris: Dalloz, 2000, p. 63).
} 
arbitrariedades e desvios de finalidade na atuação dos ocupantes de cargos e funções públicas.

Nesse contexto, embora as agências reguladoras não possuam dirigentes eleitos pelo povo e detenham elevado grau de autonomia em relação à Administração central, disso não resulta, a princípio, que padeçam de déficit democrático em sua atuação. Nas palavras de JUSTEN FILHO (2006, p. 309):

O que a democracia exige é que os titulares de determinados órgãos sejam escolhidos pelo voto, não que todo e qualquer cargo público resulte da eleição popular. Aliás, muito pelo contrário, tem de admitirse que a investidura por mérito em determinados cargos e funções públicas é inerente a um sistema democrático. Não é democrático o Estado em que todos os cargos e funções públicas são providos mediante sufrágio universal.

Os cargos e funções públicas cuja investidura se funda num critério de mérito refletem a natureza complexa do conceito de Democracia. Sua existência não padece de déficit democrático na medida em que os cargos e funções essenciais sejam providos mediante sufrágio universal. Não há déficit democrático na instituição estatal constituída sem participação direta do povo quando a função consista precisamente em neutralizar a influência da vontade da maioria da população e assegurar a realização dos valores e princípios fundamentais.

Para o autor, aludir a déficit democrático das agências independentes envolve, por tudo isso, uma simplificação, que tende a inviabilizar a discussão. Pode ou não haver déficit democrático na regulação independente, a depender de questões estruturais e funcionais externas e internas e, nessa linha, da existência de instrumentos que viabilizem a observâncias dos princípios democráticos.

LA SPINA e MAJONE (2000, p. 168 e 169) defendem que as agências reguladoras favorecem uma adequada divisão do poder, difusão esta que pode ser uma forma de controle democrático mais eficaz do que a responsabilidade direta perante os eleitores ou seus representantes. Segundo os autores, a crescente proeminência de entes reguladores em todos os países democráticos demonstra que, em muitas áreas, a confiança na sua qualidade como expertise, na discricionariedade profissional, na coerência da policy, na equidade e na independência decisória, é mais importante que atribuir a matéria a órgãos com responsabilidade política direta.

De fato, a instituição das agências reguladoras parece estar relacionada à crise de legitimidade vivenciada contemporaneamente pela grande maioria dos Estados ocidentais que deriva, dentre outros fatores, da inadequação dos 
mecanismos clássicos da Democracia para assegurar a compatibilidade entre o interesse da sociedade civil e a atuação dos representantes eleitos pelo voto. Nessa linha, JUSTEN FILHO (2006, p. 311) aponta que o advento das agências reguladoras guarda relação com uma crescente insatisfação popular contra a classe política, concebida como incapaz de sustentar o compromisso com os eleitores ou inapta a introduzir modificações significativas na atuação governamental ${ }^{13}$.

Para MARQUES NETO (2002, p. 202) é na relação com os interesses públicos que talvez se revele mais fortemente a importância das agências reguladoras nos dias de hoje. De acordo com o autor, será nestes espaços que melhor se poderá efetivar a dupla relação que compete ao poder político exercer frente aos interesses públicos: a mediação de interesses públicos dos diversos setores sujeitos à regulação específica e, concomitantemente, a proteção de interesses públicos difusos, relacionados com os consumidores, usuários de serviços, população sem acesso a alguma utilidade pública, ou ainda, a defesa dos interesses genéricos correlacionados à proteção ambiental, redução de desigualdades e outros tantos.

Sob esse ângulo, o fenômeno das agências reguladoras interage com outras inovações, tais como a consagração do princípio do devido processo administrativo, a afirmação da proteção aos interesses coletivos e difusos, a ampliação da iniciativa popular no processo legislativo, a submissão de decisões político-administrativas relevantes a consultas e audiências públicas, dentre outras. Trata-se de inovações relacionadas à implementação de meios mais adequados e eficientes para a manifestação e realização de interesses da sociedade como alternativa às soluções da teoria clássica da tripartição de poderes ${ }^{14}$.

Embora se compreenda que a ausência de eleição popular para a escolha dos dirigentes das agências reguladoras seja irrelevante para o reconhecimento de algum déficit democrático, admite-se a possibilidade de que tais entidades agravem as deficiências democráticas do sistema político em que se inserem e, nessa

\footnotetext{
${ }^{13}$ Poderia aludir-se, então, a um déficit democrático do sistema político em seu todo. Esse déficit existe antes e independentemente da instauração de agências independentes. Nessa linha, as agências independentes podem ser um instrumento para o suprimento dessa insuficiência, tal como podem prestar-se ao agravamento desse cenário (JUSTEN FILHO, 2006).

${ }^{14}$ Tal entendimento guarda relação com o conceito de democracia participativa. Segundo CANOTILHO (1999, p. 282), o princípio democrático implica democracia participativa, isto é, estruturação de processos que ofereçam aos cidadãos efetivas possibilidades de aprender a democracia, participar nos processos de decisão, exercer controle crítico na divergência de opiniões, produzir inputs políticos democráticos.
} 
hipótese, careçam de legitimidade democrática. Isso se dará sempre que os critérios de sua organização e funcionamento frustrem ou dificultem a realização dos princípios e valores fundamentais (JUSTEN FILHO, 2006).

HIPPOLITO (2003, p. 17-19) aponta a existência de quatro abismos para os quais as entidades reguladoras costumam enveredar-se:

No primeiro abismo reside o corporativismo, que aprisiona os entes do setor público. A pretexto de representar interesses gerais de toda a sociedade, acabam defendendo interesses setoriais, quando não puramente individuais. Afastam-se de suas origens, e sobretudo de suas finalidades, ou seja, a universalização da prestação do serviço. É importante lembrar que a lógica cooperativista não preenche as necessidades da democracia representativa - princípio que parece estar um pouco fora de moda, infelizmente. (...)

O segundo abismo é uma espécie de jacobinismo salvacionista que domina certos organismos do setor público. O pressuposto é o de que, por serem compostos por pessoas de reta intenção e conduta ilibada, isto é, "do bem", estes órgãos sabem o que é melhor para a sociedade. $E$ isso é assustador.

O terceiro abismo é a captura desses organismos por aqueles a quem deveriam fiscalizar, tornando-se presa fácil do clientelismo, quando não da mais deslavada corrupção.

Finalmente o quarto e perigoso abismo é o da arrogância tecnocrática, auto-suficiente e demiúrgica, que não presta contas nem aceita críticas.

Por sua vez, CANOTILHO e MOREIRA (2007, p. 138) arrolam vantagens e desvantagens quanto à atuação de entidades reguladoras independentes. Entre as vantagens apontadas pelos autores estão: i) proporcionar a especialização e o recurso a especialistas e a personalidades independentes; (ii) evitar um envolvimento direto do Governo e permitir a atenuação de sua responsabilidade política; (iii) flexibilizar e conferir celeridade de ação; (iv) agilizar as formas de participação dos interessados na tomada de decisões; (v) conseguir autosuficiência financeira. Com relação às desvantagens, os autores elencam (i) o risco de captura do organismo regulador pelos regulados; (ii) a falta de accountability perante o Congresso e perante o público; (iii) o perigo da criação de vested interests por parte dos dirigentes nomeados.

Nesse contexto, aduz-se que em um Estado democrático é salutar que existam sistemas de limitação de competências. Com efeito, a concentração de poderes discricionários em entidades organizadas segundo critérios de autonomia reforçada deve ser seguida pelo desenvolvimento de instrumentos político-jurídicos de controle e limitação. 
Disso não decorre a possibilidade de substituição das decisões emanadas por agências reguladoras, ainda que por meio de critérios de natureza técnicocientífica. Segundo JUSTEN FILHO (2006) tal controle envolve especificamente a fiscalização destinada à identificação de defeitos ou abusos no exercício das competências próprias e privativas das agências.

Por todo o exposto, os agentes reguladores se submetem a múltiplos controles: pelos Poderes Executivo, Legislativo e Judiciário, pelo Tribunal de Contas, além do controle social realizado pelo mercado e pelos consumidores (CUÉLLAR, $2008,104)$. Para os fins visados neste estudo, adotar-se-á como enfoque o controle realizado pelo Poder Judiciário. 


\section{AGÊNCIAS REGULADORAS E PODER JUDICIÁRIO}

\subsection{Controle judicial e equilíbrio regulatório}

A Constituição Federal de 1988 consagrou o princípio da universalidade da jurisdição ao dispor, em seu artigo 5ํㅡ, inciso XXXV, que a lei não excluirá da apreciação do Poder Judiciário lesão ou ameaça a direito. Assim, adotou-se, no Brasil, o modelo de jurisdição una, segundo o qual toda decisão administrativa, ainda que irrecorrível administrativamente, pode ser submetida ao crivo do Judiciário.

A esse respeito, não é demais salientar que a atual Carta Constitucional, ao contrário da anterior ${ }^{15}$, não exige, como regra, o exaurimento das vias administrativas para que haja a prestação jurisdicional ${ }^{16}$. Tal mudança privilegiou 0 princípio do amplo e livre acesso ao Judiciário, de modo que não é necessário que as entidades públicas, e assim, as agências reguladoras, se manifestem em caráter definitivo para que a lide seja submetida à apreciação judicial.

Ao tratar do controle de atos administrativos pelo Poder Judiciário, FAGUNDES (2006, p. 137) ressalta sua relevância para a realização de um controle eficiente e conforme o ordenamento jurídico:

Nos países de regime presidencial, como o nosso, ficando o Executivo, praticamente, acima das intervenções do Parlamento, que só de modo indireto e remoto influi na sua ação e a fiscaliza, cresce de importância a interferência jurisdicional, no exame da atividade administrativa. Torna-se indispensável dar-lhe estrutura e desenvolvimento correspondentes ao seu relevante papel no

\footnotetext{
${ }^{15}$ CF, de 1967 (EC n. 01, de 1969), art. 153: A Constituição assegura aos brasileiros e aos estrangeiros residentes no País a inviolabilidade dos direitos concernentes à vida, à liberdade, à segurança e à propriedade, nos têrmos seguintes:

§4 A lei não poderá excluir da apreciação do Poder Judiciário qualquer lesão de direito individual. O ingresso em juízo poderá ser condicionado a que se exauram previamente as vias administrativas, desde que não exigida garantia de instância, nem ultrapassado o prazo de cento e oitenta dias para a decisão sobre o pedido (Redação dada pela Emenda Constitucional no 7, de 1977).

${ }^{16}$ A Constituição Federal excepciona, contudo, a necessidade de esgotamento das vias administrativas da

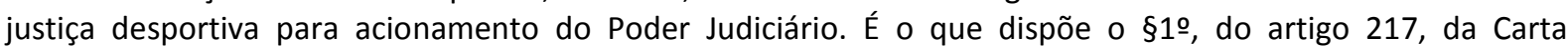
Constitucional, nos seguintes termos:
}

Art. 217. É dever do Estado fomentar práticas desportivas formais e não-formais, como direito de cada um, observados:

$\S 1$ 으 - O Poder Judiciário só admitirá ações relativas à disciplina e às competições desportivas após esgotaremse as instâncias da justiça desportiva, regulada em lei. 
vinculamento da função administrativa à ordem jurídica. $\mathrm{Na}$ realidade, é só por ele que se confina, dentro da Constituição e das leis, o exercício do Poder Executivo, que, colocado acima do controle eficiente do Parlamento, só na atuação do Poder Judiciário pode encontrar limitação eficaz do ponto de vista jurídico.

Desse modo, em relação ao Poder Judiciário, a independência das agências reguladoras não pode ser afirmada plenamente. Em verdade, sempre será possível o acionamento do Judiciário contra as suas decisões (ARAGÃO, 2009, p. 350). Todavia, o estudo do controle judicial dos atos regulatórios assume contornos próprios e especial relevância em razão da ampla discricionariedade conferida pela lei às agências reguladoras, ao caráter técnico-especializado do seu exercício e ao equilíbrio sensível entre os interesses difusos e os objetivos dos particulares envolvidos, sejam eles agentes econômicos ou consumidores.

Segundo MOREIRA e MAÇÃS (2003, p. 37), a independência das autoridades administrativas independentes encontra-se limitada, desde logo, pela existência do controle jurisdicional dos seus atos, nos termos gerais da judicial review da atividade administrativa. Para eles, embora alguns autores defendam a imunidade jurisdicional de tais entidades, por força de sua independência, a verdade é que esta tese afigura-se incompatível com a natureza administrativa que a maioria reconhece a estas entidades e, bem assim, com o princípio do Estado de direito.

Nessa linha, antes de se examinar a forma e os limites do controle judicial dos atos regulatórios, propõe-se traçar um panorama atual das relações travadas entre agências reguladoras e o Poder Judiciário, a partir da análise de dados obtidos por meio de pesquisas ${ }^{17}$ de campo e de posicionamentos doutrinários a respeito do assunto.

\subsection{Panorama do controle judicial de atos regulatórios no Brasil}

\subsubsection{Dados levantados pela Associação Brasileira da Infraestrutura e Indústrias de Base}

Estudo realizado pela Associação Brasileira da Infraestrutura e Indústrias de Base $(A B D I B)$ em 2008 revelou que à época havia 1.754 ações e execuções

\footnotetext{
17 Não se ignora que os dados levantados pelas pesquisas mencionadas no presente estudo possam não realizar um retrato fiel da realidade. De todo modo, optou-se por citá-las, uma vez que não se tem notícia de trabalhos mais rigorosos a respeito do controle judicial de atos regulatórios.
} 
contra agências reguladoras de infra-estrutura em tramitação na Justiça. Essas ações e execuções envolvem conflitos regulatórios e de direito econômico e foram ajuizadas contra as seguintes agências: Agência Nacional de Telecomunicações (ANATEL), Agência Nacional do Petróleo (ANP), Agência Nacional de Energia Elétrica (ANEEL), Agência Nacional de Transportes Aquaviários (ANTAQ), Agência Nacional de Transportes Terrestres (ANTT), Agência Nacional de Águas (ANA) e Agência Nacional de Aviação Civil (ANAC). O estudo apontou, ainda, que a judicialização de questões regulatórias possui trajetória ascendente. De fato, enquanto $14 \%$ do total de ações foram ajuizadas em 2005, 25\% delas haviam sido formuladas em 2007 (anexo A) (ANÁLISE, 2008).

Em julho de 2011, a ABDIB divulgou novo levantamento por meio do qual demonstrou que, desde 2008, a quantidade de processos aumentou em torno de $40 \%$. Segundo dados constantes da pesquisa, nesse período, 957 ações foram ajuizadas, ao passo que apenas 268 ações foram julgadas. Concluiu-se, então, que o ritmo de resolução judicial dos conflitos é quase quatro vezes menor que o de ajuizamento de novas ações (PEREIRA, 2011).

Dado que as pesquisas foram realizadas por uma associação de empresas, elas nos trazem um ponto de vista de agentes regulados quanto ao crescente ajuizamento de ações. A ABIDB apontou como conseqüências desse crescimento a criação de um ambiente de incerteza e instabilidade no gerenciamento dos negócios. A insegurança jurídica foi relacionada à imprevisibilidade do custo e do prazo para resolução do processo, bem como à inexistência de parâmetros estáveis à tomada de decisões, o que repercutiria no equilíbrio econômico e financeiro dos empreendimentos.

Segundo a pesquisa, tais incertezas significam riscos, custos e atrasos na execução de planos importantes de expansão da infra-estrutura, podendo interferir no fluxo de receitas e na rentabilidade prevista para os negócios e, sobretudo, prejudicar o atendimento às demandas da população.

De fato, notadamente quando se trata de ambiente econômico regulado, a segurança jurídica e a mitigação de riscos são variáveis determinantes do aporte e incremento de investimentos no país. Isso porque a atratividade dos investimentos está diretamente relacionada à estrita observância pelo Poder Público das regras definidas em contrato ou regulamento e, portanto, à segurança jurídica do negócio. 


\subsubsection{Dados levantados pela Universidade de São Paulo}

Em abril de 2011, o Conselho Nacional de Justiça (CNJ) divulgou relatório final de pesquisa realizada em 2010 pela Faculdade de Direito da Universidade de São Paulo (USP) com o objetivo de investigar a forma como se dá a revisão judicial das decisões administrativas de regulação e de defesa da concorrência, seus custos e efeitos sobre a eficácia regulatória. A pesquisa, pautada por critérios jurídicos, mas também econômicos, levantou dados que interessam a este estudo, uma vez que proporcionam uma visão que se pretende objetiva a respeito do controle exercido pelo Poder Judiciário em face de decisões administrativas regulatórias ${ }^{18}$.

Segundo consta do relatório da pesquisa (USP, 2011, p. 108-116), por meio de mapeamento processual da Justiça Federal, estimou-se haver 83.066 processos judiciais em que alguma agência reguladora ${ }^{19}$ consta como parte processual (anexo B).

A partir de tais resultados foi possível estimar a quantidade de ações atinentes à revisão judicial de decisões administrativas regulatórias e, portanto, relacionadas à função institucional da agência. Do universo de processos judiciais envolvendo agências reguladoras, foram excluídos os casos considerados não pertinentes, ou seja, que não se referem à revisão judicial de decisões administrativas regulatórias, e não essenciais, isto é, não diretamente relacionados à decisão administrativa impugnada ${ }^{20}$ (USP, 2011, p. 116-129).

\footnotetext{
${ }^{18}$ Embora a revisão judicial das decisões do Conselho Administrativo de Defesa Econômica - CADE integrem o objeto da pesquisa realizada pela USP, de modo geral, os dados levantados destacam os resultados relativos ao órgão daqueles atinentes às agências reguladoras, pelo que não mitigam a pertinência da pesquisa para o presente estudo.

${ }^{19}$ Consta da pesquisa (USP, 2011, p. 108) que foram incluídas inicialmente as seguintes agências: ANA, ANAC, ANATEL, ANCINE, ANEEL, ANP, ANS, ANTAQ, ANTT e ANVISA. Após conversa com o Procurador-Geral Federal, aceitou-se a sugestão de inclusão da CVM e Previc.

${ }^{20}$ Nessa linha, foram excluídos processos relacionados a questões meramente administrativas, como litigância entre servidores públicos e autarquia, concurso público para ingresso no quadro de pessoal, licitação para compra de bens de consumo ou contratação de serviços de base à atuação da agência (material de escritório, alimentação, segurança), entre outras não relacionadas à atividade regulatória. A respeito dos processos excluídos, confira-se informação constante da pesquisa (USP, 2011, p. 129, nota 153): A definição do que é um processo 'pertinente' à pesquisa ou 'essencial' não é absolutamente objetiva como se desejaria. Por vezes, o pesquisador se depara com situações concretas em que não é possível assegurar com precisão em qual categoria os processos se enquadram. Em situações que suscitavam dúvidas, a coordenação da pesquisa optou por ser mais inclusiva, incorporando tais casos à amostra. O impacto dessa decisão sobre as estimativas econométricas é desprezível, dado o tamanho da amostra, e de pequena relevância no caso de estatísticas descritivas, mesmo nas situações em que as informações são estratificadas por autarquias.
} 
Assim, estimou-se o ajuizamento de 38.641 ações cujo escopo seja a revisão de decisões finalísticas de agências reguladoras. Da análise de amostra desse total (USP, 2011, p. 129-165), foram extraídos indicadores de custo e de incerteza jurídica. Os resultados pertinentes a este trabalho serão relatados em síntese no passo seguinte.

A pesquisa revelou que a taxa de confirmação de decisões administrativas pelo Judiciário corresponde a cerca de $60 \%$ das ações transitadas em julgado. Apenas 3,3\% das decisões administrativas questionadas judicialmente foram parcialmente reformadas e 8,5\%, anuladas. Os demais processos, que representam $28,7 \%$ do total, foram extintos sem julgamento de mérito ${ }^{21}$ (anexo $\left.\mathrm{C}\right)^{22}$.

Caso somente sejam considerados os processos em que houve decisão quanto ao mérito, o percentual de decisões administrativas confirmadas judicialmente sobe para $83 \%$, contra $12 \%$ de decisões anuladas e $5 \%$ de parcialmente reformadas (anexo D).

De acordo com o relatório da pesquisa, essa informação indica, ainda que de modo indireto e precário, que os benefícios diretos da revisão judicial não parecem substanciais. Não se discutem, em abstrato, os benefícios e o papel da revisão judicial em assegurar direitos e maior qualidade do enforcement das normas regulatórias. Contudo, no particular da revisão judicial no Brasil, a baixa taxa de atuação como revisora de decisões administrativas indica que este papel não é de relevância expressiva.

A título de argumentação se conjectura que ainda que todas as modificações judiciais das decisões administrativas fossem adequadas, dado que apenas $17 \%$ das decisões são modificadas, incorrer-se-ia no custo de postergar o enforcement regulatório dos restantes $83 \%$ das decisões administrativas. (USP, 2011, p. 145-146).

Também a análise do tempo transcorrido para a decisão final é considerada um resultado particularmente importante da pesquisa, uma vez que a

\footnotetext{
${ }^{21}$ Mérito assume, aqui, sua acepção processual. A observação é relevante uma vez que, mais adiante, se analisará o exame judicial do mérito da decisão administrativa, partindo-se de noção própria ao direito administrativo.

${ }^{22}$ O elevado índice de decisões sem julgamento de mérito suscita a dúvida quanto ao preparo dos magistrados para julgar questões regulatórias, tema que será analisado no decorrer desta monografia.
} 
aplicação da norma regulatória deve ser tempestiva, sob pena de sua ineficácia ${ }^{23}$. A USP apontou haver uma percepção generalizada de excessiva morosidade para as decisões definitivas do Judiciário. De acordo com os dados levantados, a média de duração das ações judiciais analisadas é de 36 meses. Tal morosidade se acentua na revisão das decisões das agências reguladoras, cujas decisões são feitas por colegiado e cujos objetos são sensíveis ao tempo.

Ainda quanto ao tempo de tramitação no Judiciário, observa-se que, nos casos onde houve decisão de mérito, o tempo de análise foi sensivelmente superior, cerca de 58 meses. Nos casos em que o Judiciário não confirmou a decisão administrativa, esse tempo aumentou para 69 meses (5,7 anos). Em outras palavras, nos processos em que o Judiciário interveio de forma substancial, seja anulando ou alterando parcialmente a decisão administrativa, o tempo para análise foi de aproximadamente 69 meses, 92\% maior do que o tempo médio total (36 meses) (anexo E).

Salienta-se que os dados acima foram obtidos a partir da análise dos casos transitados em julgado. Considerando que tais processos representam apenas $16 \%$ do total estimado, é possível que se trate de grupo com características distintas dos demais. Assim, o estudo restrito dos casos transitados em julgado pode distorcer conclusões, dada sua pequena representatividade em relação ao total de processos. Por exemplo, é razoável admitir que os casos transitados em julgado sejam mais simples que os demais e, por essa razão, tenham sido concluídos. Sendo assim, a estimativa apresentada estaria subestimando o tempo de trâmite total. De fato, a análise dos processos em andamento parece indicar que essa hipótese seja verdadeira.

Conforme dados levantados na pesquisa (anexo F), o tempo médio transcorrido dos casos ainda pendentes de decisão definitiva é de 54 meses, enquanto o tempo médio dos transitados em julgado é de apenas 36 meses.

Com o escopo de definir uma medida do tempo de duração mais próxima do real, evitando a elevada subestimação que ocorre ao se observar apenas os

\footnotetext{
${ }^{23}$ Sobre as conseqüências do entrave regulatório para a realização de pesquisas clínicas no Brasil, confira-se matéria publicada pela Associação Brasileira de Organizações Representativas de Pesquisa Clínica (ABRACRO), disponível em: <http://www.abracro.org.br/br/pesquisa-clinica/pesquisa-clinica-no-brasil/entravesregulatorios>. Acesso em: 27 nov. 2011.
} 
casos transitados em julgado, a USP estimou o tempo de trâmite mínimo, considerando a hipótese extrema de que todos os casos em andamento fossem concluídos instantaneamente no momento da pesquisa. Desse modo, avaliou que, no mínimo, o tempo de duração dos processos envolvendo agências reguladoras supera quatro anos (50 meses).

Ademais, observou-se que as decisões judiciais de primeira instância destoam consideravelmente das decisões judiciais definitivas ${ }^{24}$. Veja-se, como exemplo, a taxa de anulação de decisões administrativas, que corresponde a $22,50 \%$ dos casos analisados em primeira instância, contra 8,50\% dos casos transitados em julgado (anexo G).

Se comparados apenas os casos em que houve julgamento de mérito, é mais significativa a diferença entre decisões de primeira instância e decisões transitadas em julgado. Nos casos em que o Judiciário se manifestou sobre o mérito, a taxa de confirmação em decisão final supera em torno de $15 \%$ à de decisões de primeira instância (anexo $\mathrm{H}$ ).

Tais resultados são relevantes para a estimativa de custos de revisão judicial, sobretudo no que se refere à incerteza jurídica. As diferenças apontadas registram que há considerável alteração de entendimento do Judiciário no decorrer do processo, bem como denotam que Judiciário se pronuncia em primeira instância de modo mais invasivo do que o faz em caráter definitivo. Os dados parecem apontar uma postura mais conservadora das cortes superiores, que estariam menos propensas a adentrar o mérito administrativo.

Segundo relatado na pesquisa, a conseqüência desse fato é deletéria à adequada aplicação da norma, uma vez que transmite, no curso do processo, sinais conflitantes à sociedade. Além disso, a forte tendência de confirmação da decisão administrativa ao final indica que não há benefícios relevantes no controle judicial de atos regulatórios em face do estado de incerteza a que empresas, concorrentes e a própria autoridade regulatória são submetidos (USP 2011, p. 14).

Entretanto, ao contrário da conclusão apontada na pesquisa, entende-se que a tendência dos tribunais em manter a decisão das agências reguladoras não implica, necessariamente, a ausência de benefícios relevantes no controle judicial de

\footnotetext{
${ }^{24}$ Os dados trazidos pela USP na pesquisa citada comparam as decisões de primeira instância com as decisões transitadas em julgado, embora estas possam compreender parte daquelas, tendo em vista que também as decisões de primeira instância podem tornar-se definitivas.
} 
atos regulatórios. Primeiro porque os dados correspondem a um recorte da realidade, pelo que não é possível concluir que essa tendência se perpetue. Ademais, importa mencionar que a existência de 16,4\% de alterações em decisões de mérito transitadas em julgado não deve ser menosprezada, sobretudo porque, desconhecendo o conteúdo de tais decisões, parece pouco razoável inferir sua relevância com base apenas em critérios quantitativos.

Conquanto se entenda que a taxa de confirmação das decisões administrativas não permite conclusões precisas acerca da relevância do controle judicial, também se reconhece que as alterações do provimento judicial no curso do processo elevam a insegurança jurídica e comprometem o equilíbrio econômico do setor, equilíbrio esse o qual cumpre às agências reguladoras garantir.

Em síntese e, para além dos resultados narrados, o diagnóstico elaborado a partir da pesquisa aponta que o Judiciário (USP, 2011, p. 304):

(a) consome tempo excessivo para responder em definitivo às demandas de revisão, (b) com frequência concede liminares suspensivas dos efeitos da decisão administrativa e da atividade instrutória, (c) os provimentos liminares —-mudam de sinal excessivamente (são revogadas e novamente concedidas no curso do sistema recursal), (d) a qualidade técnica das decisões é baixa (em particular revelam despreparo pessoal e institucional para apreciar políticas regulatórias, questões técnicas econômicas ou setoriais e ponderar interesses individuais e coletivos em jogo) e (e) os tribunais superiores mostram uma tendência a confirmar a decisão das agências.

Nesse contexto, conclui-se que, ao combinar a intervenção suspensiva de atos das agências com a confirmação da decisão após longo tempo de oscilações por parte dos órgãos julgadores, o Poder Judiciário dá uma sinalização ruim às agências e ao mercado ${ }^{25}$.

\subsubsection{Segurança jurídica e equilíbrio regulatório}

\footnotetext{
25 No ponto, interessa trazer à baila a sugestão apresentada por BRUNA (2003, p. 279, nota 54), que demandaria, contudo, a edição de emenda constitucional: (...) seria prudente instituir foro privilegiado para o julgamento de ações da espécie, a fim de evitar que algumas políticas públicas acabassem inviabilizadas pela oposição de um grande número de decisões dos juízos monocráticos espalhados pelo país, sendo talvez o caso de atribuir a competência para o julgamento de certas causas diretamente aos tribunais de segunda instância. A multiplicidade, incongruência e transitoriedade de decisões monocráticas, principalmente as de caráter liminar, em situações tais, gera um sentimento social de desconfiança quanto à capacidade do Poder Judiciário de desempenhar adequadamente seu papel.
} 
De acordo com PARENTE (2001, p. 12), as agências devem assegurar a realização de investimentos para continuar a prover as atividades econômicas reguladas. Se o Estado se exime de atuar e investir diretamente em uma determinada área e, no entanto, não surgem os investimentos, pode haver problemas graves no provimento dos serviços às famílias, às companhias e à sociedade em geral. Nessa linha, o autor defende a importância de que o controle não seja visto como um fim, mas como uma forma de assegurar que estas agências funcionem, atendendo os seus objetivos principais e dentro de custos razoáveis.

Nesse contexto, a imprevisibilidade das decisões do Judiciário e, assim, a ingerência nas convenções pactuadas no ambiente regulado podem reverter-se em insegurança jurídica. A insegurança quanto à execução dos termos contratados, por sua vez, pode comprometer o equilíbrio regulatório e, nesse contexto, impactar negativamente também o consumidor comum, gerando efeito inverso ao desejado pelo órgão jurisdicional.

Com efeito, a regulação de uma atividade econômica envolve continuamente a tomada de decisões de grande transcendência para os regulados: são fixados preços, quantidades, quotas, prazos, entre outros parâmetros. Por essa razão, as medidas regulatórias devem basear-se também na análise econômica das decisões, de modo que seja possível prever as conseqüências dos atos regulatórios não só a curto, mas, também, a médio e longo prazo (ORTIZ, 2005). Assim é que a ausência de especialização técnica dos magistrados quanto a temas regulatórios específicos, sem que se recorra a provas periciais ou à assessoria capacitada, em alguma medida pode significar a prolação de decisões não somente imprevisíveis, mas também atécnicas.

A respeito da segurança jurídica necessária ao equilíbrio do setor regulado, confira-se a resposta de MENDES (2004, p. 123), ao ser questionado sobre a possibilidade revisão judicial de aspectos como as tarifas fixadas pelas agências reguladoras.

Pergunta dificílima, porque, obviamente, num sistema universalmente judicialista como esse nosso, difícil indicar um tema que não poderia ser objeto de eventual judicialização. Por outro lado, nós sabemos que a banalização desse tipo de intervenção também tem um custo e provoca profunda instabilidade. (...) Certamente a teleologia dessas agências reguladoras [envolve] razões ligadas a maior estabilidade que esses órgãos tenham até uma estrutura que eventualmente transcenda o mandato comum dos políticos, dos exercentes dos mandatos tradicionais, de modo a garantir essa estabilidade para 0 
sistema, o que, talvez, até pudesse provocar uma modicidade dos preços a perspectiva de retorno de investimentos, dentro de prazos mais ou menos seguros.

A judicalização dessas questões, ainda mais num sistema difuso, que gera, como nós sabemos, um quadro muitas vezes confuso, provoca muita insegurança, e, ao invés de termos a redução dos preços, é muito provável que, num cenário de médio prazo, uma outra situação seja provocada. Talvez aqui a gente devesse discutir se é o caso de judicializar, se não haveria de ter competências especiais, ou definições dessa índole, porque é muito provável que a judicialização aberta dessas questões produza efeito contrário ao pretendido.

Mas acho que, num sistema como o nosso é difícil evitar a judicialização. (...) O que se pode depois é dizer que esse controle em tal detalhe é inadmissível, ou que está havendo um tipo de invasão da competência muito mais incisiva por parte do próprio Judiciário.

De fato, a estabilidade do sistema regulado é fundamental à qualidade dos serviços prestados, ao aporte de investimentos pelos agentes privados e, a depender do caso, à modicidade tarifária.

Com efeito, a própria instituição de agências reguladoras no Brasil, no contexto do movimento de privatização, acentuado na década de 90 , deu-se sob a justificativa de que, com a privatização das empresas estatais prestadoras de serviços públicos e a instituição de concorrência entre as mesmas, havia necessidade de órgão especializado para organizar o setor, manter o equilíbrio do mercado e resolver os conflitos entre as prestadoras de serviços ou entre estas e o usuários (DI PIETRO, 2003, p. 46).

Nessa linha, convém lembrar que MOREIRA (1997a, p. 29), ao citar o pensamento de WRIGHT, HANCHER \& MORAN e JONGEN, aponta duas idéias que se ligam ao conceito etimológico de regulação: primeiro, a idéia de estabelecimento e implementação de regras, de normas; em segundo lugar, a idéia de manter ou restabelecer o funcionamento equilibrado de um sistema.

A noção de estabilidade regulatória está relacionada à idéia de credibilidade da ação regulatória (commitment problem ou regulatory commitment). Para MELO (2001, p. 64), a credibilidade é uma questão basilar na criação das agências regulatórias porque os investimentos associados à privatização das empresas de utilidade pública são de grande valor e o retorno recuperável em um horizonte temporal de grande magnitude. Por esse prisma, o poder decisório das agências reguladoras é conexo à necessidade de assegurar que os contratos serão 
observados no futuro e de que não haverá alterações substanciais nas regras do jogo, estabelecidas no contexto de abertura da economia brasileira.

A credibilidade na atuação dos agentes reguladores também é apontada por ORTIZ (2004), que salienta a necessidade de transparência e de estabilidade das regras que envolvem a regulação:

\begin{abstract}
Para ello, es fundamental que en el ejercicio de la actividad reguladora se cumplan también los requisitos generalmente exigidos para toda la actividad administrativa: toda regulación debe ser elaborada con carácter general, objetivo y global, como es propio de toda norma, no debe admitir dispensas ni tratamientos singulares (inderogabilidad singular de las normas) ni alteración arbitraria y ocasional de las reglas del juego. Estas deben ser claras y estables, bien determinadas, no discrecionales, de forma que las empresas puedan diseñar sus propias políticas de actuación, a la vista de ellas.
\end{abstract}

Es importante insistir en la necesidad de transparencia y estabilidad en las reglas en el modelo de regulación para la competencia: que exista seguridad jurídica en cuanto a su aplicación y que las conductas produzcan efectos previsibles. Este requisito podría traducirse en un rasgo fundamental del regulador, no cuantificable, pero muy importante: la credibilidad.

A relevância de se garantir a estabilidade do setor regulado não se refere tão-somente ao equilíbrio econômico-financeiro dos contratos firmados com as concessionárias de serviço público ${ }^{26}$. Tal como exposto no capítulo anterior, cumpre às agências reguladoras a dupla função de arbitrar interesses e, paralelamente, tutelar os interesses difusos enredados na sua atividade (MARQUES NETO, 2002, p. 202).

Com efeito, o que se exige ao regular setores sensíveis é uma intervenção que garanta o pluralismo e o equilíbrio entre valores contrapostos e entre os interesses dos mercados e os fins de serviços públicos. Essa maneira de atuar, no marco de um ordenamento em grande parte indefinido, não é própria da

\footnotetext{
${ }^{26}$ A respeito do equilíbrio econômico-financeiro de contratos de concessão, cite-se conceito formulado por MELLO (2002, p. 643): Concessão de serviço público é o instituto através do qual o Estado atribui o exercício de um serviço público a alguém que aceita prestá-lo em nome próprio, por sua conta e risco, nas condições fixadas e alteráveis unilateralmente pelo Poder Público, mas sob garantia contratual de um equilíbrio econômicofinanceiro, remunerando-se pela própria exploração do serviço, em geral e basicamente mediante tarifas cobradas diretamente dos usuários do serviço.
} 
Administração e, tampouco do Judiciário. Requer outra legitimação e outra expertise (MAS, 1999, p. 69) ${ }^{27}$.

Além disso, conforme apontado por ARAUJO (2010, p. 133), há a possibilidade de que a regulação seja suspensa no curso de relação processual em que não se repita a pluralidade verificada quando da formação da norma. Isso porque, como destacado no capítulo anterior, a legitimidade democrática das agências reguladoras envolve a participação pública na formação (institucionalização) do conteúdo da regulação durante os processos decisórios (MATTOS, 2006, p. 205-246). Entretanto, a mesma abertura democrática não se observa no trâmite do processo no Judiciário.

Não se pretende, contudo, defender que o controle judicial de atos regulatórios seja de todo prejudicial ao equilíbrio do setor regulado. Ao contrário, como se sustentou anteriormente, tal modalidade de controle é fundamental para evitar que a autonomia inerente à atividade regulatória se converta em arbitrariedade. Não se ignora que, por vezes, o Judiciário será invocado justamente para garantir a observância de um regulamento editado por dada agência reguladora ou mesmo para avaliar as condições procedimentais de participação de grupos de interesse nas deliberações sobre o conteúdo da regulação.

Como ressaltado na pesquisa realizada pela USP, a simples existência da revisão judicial já provoca um efeito positivo nas agências reguladoras no sentido de se estruturarem melhor e explicitarem os motivos técnicos de suas decisões com clareza e buscando pacificar os interesses afetados. Contudo, para ser eficaz, o controle judicial deve congregar qualidade e capacidade de oferecer respostas em tempo concorrencial, ou seja, em um prazo compatível com a celeridade das transformações de mercado.

\footnotetext{
${ }^{27}$ Note-se que a complexidade da atuação das agências reguladora, que envolve a intervenção em setores da economia i) sem afastar a participação dos agentes privados; ii) separando as tarefas de regulação das de exploração de atividade econômica, mesmo quando remanescer atuando no setor por ente controlado seu; iii) orientando sua intervenção predominantemente para a defesa dos interesses dos cidadãos enquanto participantes das relações econômicas travadas no setor regulado; iv) procurando manter o equilíbrio interno ao setor regulado de modo a permitir a preservação e incremento das relações de competição (concorrência), sem descurar da tarefa de imprimir ao setor pautas distributivas ou desenvolvimentistas típicas de políticas públicas; e, por fim, v) exercendo a autoridade estatal por mecanismos e procedimentos menos impositivos e mais reflexivos (permeáveis à composição e arbitramento de interesses), o que envolve maior transparência e participação na atividade regulatória (MARQUES NETO, 2003, p. 19).
} 
Quanto ao ponto, embora não se ignore que o controle judicial seja, em regra, posterior à decisão administrativa, pelo que jamais poderá acompanhar a velocidade do fenômeno regulatório, não é demais ressaltar a relevância do tempo para a efetividade da regulação.

Segundo ORTIZ (2004, p. 643), a atividade regulatória deve promover o funcionamento de uma realidade. Essa realidade é o momento atual do serviço público ou da atividade econômica regulada, que não pode sofrer interrupções e deve ser ajustados e ordenados em momento imediatamente subsequente à constatação de sua falta de qualidade, desequilíbrio econômico, problemas de segurança, entre outros. Nessa linha, exige-se da decisão contemporaneidade e adequação técnica.

Além disso, entende-se que, ao decidir, os magistrados devem ponderar que os efeitos de sua decisão não só incidem sobre os integrantes dos pólos da relação processual, como também interferem no equilíbrio regulatório a que as agências visam a resguardar. Sob essa perspectiva, confira-se precedente do Superior Tribunal de Justiça (STJ) em que se realizou tal ponderação:

ADMINISTRATIVO. TELECOMUNICAÇÕES. TELEFONIA FIXA. LEI N. 9.472/97. COBRANÇA DE TARIFA INTERURBANA. SUSPENSÃO. ÁREA LOCAL. AÇÃO CIVIL PÚBLICA. CÓDIGO DE DEFESA DO CONSUMIDOR. 1. A regulamentação do setor de telecomunicações, nos termos da Lei n. 9.472/97 e demais disposições correlatas, visa a favorecer o aprimoramento dos serviços de telefonia, em prol do conjunto da população brasileira. Para o atingimento desse objetivo, é imprescindível que se privilegie a ação das Agências Reguladoras, pautada em regras claras e objetivas, sem o que não se cria um ambiente favorável ao desenvolvimento do setor, sobretudo em face da notória e reconhecida incapacidade do Estado em arcar com os eventuais custos inerentes ao processo. 2. A delimitação da chamada "área local" para fins de configuração do serviço local de telefonia e cobrança da tarifa respectiva leva em conta critérios de natureza predominantemente técnica, não necessariamente vinculados à divisão político-geográfica do município. Previamente estipulados, esses critérios têm o efeito de propiciar aos eventuais interessados na prestação do serviço a análise da relação custo-benefício que irá determinar as bases do contrato de concessão. 3. Ao adentrar no mérito das normas e procedimentos regulatórios que inspiraram a atual configuração das "áreas locais" estará o Poder Judiciário invadindo seara alheia na qual não deve se imiscuir. 4. Se a prestadora de serviços deixa de ser devidamente ressarcida dos custos e despesas decorrentes de sua atividade, não há, pelo menos no contexto das economias de mercado, artifício jurídico que faça com que esses serviços permaneçam sendo fornecidos com o mesmo padrão de qualidade. $O$ desequilíbrio, uma vez instaurado, vai refletir, diretamente, na impossibilidade prática 
de observância do princípio expresso no art. 22,caput, do Código de Defesa do Consumidor, que obriga a concessionária, além da prestação contínua, a fornecer serviços adequados, eficientes e seguros aos usuários. (STJ, REsp n. 572.070/PR 2003/0128035-1, Segunda Turma, Rel. Min. João Otávio de Noronha, julgado em 16.03.2004, DJ de 14.06.2004)

Embora a decisão toque a questão da análise do mérito das normas e procedimentos regulatórios pelo Judiciário, optou-se por examinar o tema em momento posterior. De todo modo, observa-se da leitura do acórdão uma preocupação do órgão julgador com a repercussão econômica de sua decisão. Mais do que isso, houve uma reflexão sobre os efeitos que o desequilíbrio regulatório poderia gerar sobre os demais usuários do serviço de telefonia. A propósito, em seu voto, o relator do processo teceu críticas à decisão recorrida, nos seguintes termos:

Não concebo como se possa interferir de forma tão radical em um setor de tamanha complexidade e sensibilidade como é o das comunicações com base em mera presunção de que prestadora de serviços dispõe, na área questionada, de uma adequada engenharia de rede de telecomunicações.

A despeito da importância da estabilidade regulatória, ressalta-se que não deve juiz abster-se de examinar o conteúdo do ato regulatório. Tal generalização atentaria contra a própria efetividade do controle judicial. Ao mesmo tempo, parece ser insuficiente a mera recomendação de que o Judiciário atue com parcimônia. Por essa razão, propõe-se, ao passo seguinte, analisar os limites da revisão judicial de atos regulatórios. 


\section{LIMITES DO CONTROLE JUDICIAL DE ATOS REGULATÓRIOS}

A doutrina diverge quanto à extensão do controle judicial de atos regulatórios. Tampouco na jurisprudência pátria esses limites se revelam bem definidos. Nesse contexto, serão estudados a seguir diferentes entendimentos acerca do alcance do controle judicial de atos regulatórios ${ }^{28}$.

\subsection{Controle de legalidade e controle de mérito}

FAGUNDES (2006, p. 167), um dos precursores do assunto no Brasil, relacionava mérito ${ }^{29} \mathrm{com}$ discricionariedade e sustentava ser vedado ao Judiciário apreciar, no exercício do controle jurisdicional, o mérito dos atos administrativos. Segundo o autor, pela necessidade de subtrair a Administração Pública a uma prevalência do Poder Judiciário, capaz de diminuí-la, ou até mesmo de anulá-la em sua atividade peculiar, põem-se restrições à apreciação jurisdicional dos atos administrativos, no que respeita à extensão e conseqüências. Assim, FAGUNDES defendia caber ao Judiciário examiná-los, tão somente, sob o prisma da legalidade.

Em semelhante sentido, para limitar o controle judicial de atos administrativos ao crivo da legalidade, MEIRELLES (1997, p. 610-612) expôs que o controle judiciário seria um controle a posteriori, unicamente de legalidade, pois restrito à verificação da conformidade do ato com a norma legal que o rege. De acordo com o autor, não se permitiria ao Judiciário pronunciar-se sobre o mérito administrativo, ou seja, sobre a conveniência, oportunidade, eficiência ou justiça do

\footnotetext{
${ }^{28}$ Para tanto, optou-se por introduzir o tema a partir das obras de FAGUNDES (2006) e MEIRELLES (1997) acerca do controle judicial de atos administrativos. Explica-se. Embora o objetivo deste estudo incida sobre os atos relacionados aos fins institucionais das agências reguladoras, pôde-se constar, no decorrer da pesquisa, que os posicionamentos doutrinários a esse respeito, de modo geral, partem das visões de tais autores, direta ou indiretamente, quer para adotá-las, em alguma medida, quer para rechaçá-las. Assim, se em alguns pontos serão trazidos entendimentos sobre o controle judicial de atos administrativos comuns, o objetivo último deste recorte doutrinário será a reflexão sobre as divergências existentes quanto ao controle judicial de atos administrativos regulatórios.

${ }^{29}$ DI PIETRO (2007, p. 127) aponta a dificuldade da utilização do vocábulo mérito, que tem sentido diverso nos âmbitos do direito processual e administrativo. "No primeiro, mérito é a própria pretensão que o autor deduz em juízo, com base em normas de direito substantivo, opondo-se às questões preliminares, que têm cunho processual. No direito administrativo, embora se possa empregar o vocábulo nesse mesmo sentido, já que existe também um processo administrativo, na realidade, o sentido mais usual é o que concerne aos aspectos do ato administrativo relacionados basicamente com o princípio da oportunidade e conveniência, em face do interesse público a atingir".
} 
ato, porque, se assim agisse, estaria emitindo pronunciamento de administração, $e$ não de jurisdição judiciária. Assim, o mérito administrativo, relacionando-se com conveniências do governo ou com elementos técnicos, escaparia do âmbito do Poder Judiciário.

Nessa linha, o exame de legalidade seria o limite do controle, quanto à extensão, do controle judicial. Com relação às conseqüências decorrentes desse controle, para FAGUNDES (2006) o Judiciário deveria limitar-se a negar efeito aos atos administrativos em cada caso especial. Assim é que o autor entendia que $O$ pronunciamento do órgão jurisdicional nem analisa o ato do Poder Executivo, em todos os aspectos, nem o invalida totalmente.

O entendimento esposado pelos autores ainda encontra lugar na jurisprudência, como se constata dos precedentes a seguir:

ADMINISTRATIVO. RÁDIO COMUNITÁRIA. PRESTAÇAO DE SERVIÇO. PEDIDO DE AUTORIZAÇAO. CONCESSAO PELO PODER JUDICIÁRIO. IMPOSSIBILIDADE.

1. A controvérsia cinge-se em saber se há possibilidade ou não de o Poder Judiciário autorizar o exercício precário do serviço de radiodifusão comunitária, até que a Administração decida definitivamente a questão.

2. O procedimento administrativo, que tem por objeto verificar os requisitos da Lei no 9.612/98 e do Decreto 2.615/98, não pode ser substituído por provimento jurisdicional que autorize o funcionamento da rádio, já que não compete ao Poder Judiciário adentrar no mérito do ato administrativo.

3. Constatado atraso injustificado no exame do pedido de autorização para funcionamento de rádio comunitária, o órgão jurisdicional pode fixar prazo razoável para que a mora administrativa seja sanada, desde que, é claro, exista pedido na inicial nesse sentido. Na espécie, não houve requerimento, o que inviabiliza tal solução. Precedentes: EREsp 1.100.057/RS, Rel. Min. Eliana Calmon, DJe de 10.11.09; EDcl no AgRg no Ag 1.161.445/RS, Rel. Min. Mauro Campbell Marques, DJe de 24.08.10; REsp 1.019.317/MG, Rel. Min. Castro Meira, DJe de 11.11.09; REsp 1.006.191/PI, Rel. p/ Acórdão Min. Castro Meira, Segunda Turma, DJe 18.12.08.

4. Recurso especial provido.

(STJ, REsp n. 1.123.343/RS - 2009/0027242-2, Segunda Turma, Rel. Min. Castro Meira, julgado em 08.06.2010, DJe de 15.10.2010)

PROVA PERICIAL. INDEFERIMENTO. FACULDADE DO JUIZ. ART. 130 DO CPC. DIREITO ADQUIRIDO A UTILIZAÇÃO DE RADIOFREQUÊNCIA. INEXISTÊNCIA. BEM PÚBLICO ADMINISTRADO PELA ANATEL. MÉRITO ADMINISTRATIVO. VIOLAÇÃO AO EXERCÍCIO DA ATIVIDADE ECONÔMICA. INOCORRÊNCIA. 
1.- $O$ poder instrutório do juiz, a teor do que dispõe o art. 130 do Código de Processo Civil, permite-lhe o indeferimento de provas que reputar desnecessárias para firmar seu juízo de convicção.

2.- Não pode a autora, como permissionária, pretender possuir direito adquirido à utilização de determinadas freqüências ou faixas, uma vez que estas, assim como as permissões, são passíveis de modificação e até de extinção, sendo bem público administrado pela agência reguladora.

3.- Atuado a ANATEL dentro dos parâmetros legais e nos limites de suas atribuições, não cabe ao Poder Judiciário adentrar no mérito da alteração de radiofreqüência efetuada, sob pena de ingerência indevida na Administração Pública.

4.- Não se configura a violação ao art. 5ํㅓ. XIII, da CF/88, pois a autora não está impedida de exercer sua atividade econômica, nem houve restrição ao exercício desse direito.

(TRF4, AC 48.806/RS, Terceira Turma, Rel. Des. Maria Lúcia Luz Leiria, julgado em 30.03.2010, D.E. de 28.04.2010)

ADMINISTRATIVO. PROCESSUAL CIVIL. INDEFERIMENTO DA PETIÇÃO INICIAL. OCORRÊNCIA DE PEDIDO JURIDICAMENTE IMPOSSÍVEL.

1. Objetiva-se, nesta ação, preliminarmente, a entrega das faturas de energia elétrica "[...] emitidas em nome da suplicante, em mão própria mediante apresentação de protocolo, com antecedência de cinco dias úteis antes do vencimento" e no mérito, a "resilição" (nos termos do pedido) do contrato de concessão de venda de energia elétrica, em regime de monopólio, celebrado entre a CELPE Companhia Energética de Pernambuco S/A, a União e a ANEEL Agência Nacional de Energia Elétrica, sob o fundamento de prática de métodos comerciais desleais e coercitivos praticados pela CELPE (corte de energia elétrica), para 0 fim de que nova prestadora/fornecedora seja habilitada a vender energia elétrica no Estado de Pernambuco.

2. A impossibilidade jurídica do pedido é evidente, considerando ser vedado ao Poder Judiciário substituir o Poder Público para intervir no critério de oportunidade e conveniência inerente à Administração da prática de ato administrativo, no caso, de firmar contrato de concessão de serviço público de energia elétrica.

3. Merece ser mantida a sentença recorrida, por impossibilidade jurídica do pedido.

4. Apelação improvida.

(TRF 5a Região, AC n. 451.548/PE - 0010491-41.2008.4.08.8300,

Primeira Turma, Rel. Des. Rogério Fialho Moreira, julgado em 15.04.2010, DJE de 23.04.2010, p. 138)

Por seu turno, DI PIETRO (2007, p. 130) entende não ser possível negar a veracidade da afirmação de que ao Judiciário é vedado controlar o mérito, o aspecto político do ato administrativo, que abrange, sinteticamente, os aspectos de oportunidade e conveniência.

A autora defende, contudo, ser inaceitável a utilização do vocábulo "mérito" como escudo à atuação judicial, em situações que, de fato, envolvam 
questões de legalidade e moralidade administrativas. Desse modo, sustenta ser necessário colocar a discricionariedade em seus devidos limites, a fim de impedir arbitrariedades que a Administração pratica sob 0 pretexto de agir discricionariamente em matéria de mérito.

Do exposto decorre a importância que a autora atribui aos princípios limitadores da discricionariedade administrativa, como moralidade, razoabilidade $e$ interesse público (2007, p. 130). Segundo DI PIETRO, esses princípios deram feição nova ao princípio da legalidade.

Nessa esteira, a autora sustenta a possibilidade de exercício de controle judicial quanto a atos normativos concretos e gerais exarados por agências reguladoras, inclusive para invalidação das normas. Quanto a estas, DI PIETRO (2006) defende a apreciação de sua validade pelo Judiciário, quer com auxílio de peritos, quando se tratar de conceitos puramente técnicos, quer pela aplicação dos princípios da razoabilidade das normas e do devido processo legal substantivo. Entretanto, para a autora, tal controle não seria um controle de mérito, mas um controle de legalidade, com enfoque na observância dos princípios limitadores da discricionariedade administrativa.

BARROSO (2002, p. 126 e 127) também recorre aos princípios constitucionais para tratar do controle judicial dos atos regulatórios. Porém, para o autor, tal análise importa, de fato, em um controle de mérito.

Segundo BARROSO, o entendimento clássico que obsta o controle de mérito sobre atos administrativos atualmente cede lugar aos princípios da razoabilidade, moralidade e eficiência. Tais princípios excepcionariam a insindicabilidade do mérito administrativo. Para o autor, a análise da razoabilidade do ato, ou seja, da adequação entre meio e fim, necessidade e proporcionalidade, seria, evidentemente um controle de mérito. Contudo, se por um lado a aplicação de tais princípios expandiria o controle sobre atos administrativos, por outro, nela estariam definidos os limites desse controle. Isso porque, para BARROSO, o controle de mérito somente seria possível nas hipóteses de verificação da razoabilidade, moralidade e eficiência do ato. 
Além disso, o autor salienta que, tratando-se de matéria própria às agências reguladoras, o Judiciário deve ser deferente ${ }^{30}$ em relação às decisões administrativas. Nessa linha, o controle judicial teria como limite o teste de razoabilidade, moralidade e eficiência, notadamente quanto a decisões balizadas por critérios técnicos, sob pena de cair no domínio da incerteza e do subjetivismo.

Embora DI PIETRO e BARROSO divirjam quanto à natureza do controle defendido (para a primeira, controle de legalidade revisitado, para o último, controle de mérito), observa-se que eles possuem em comum a utilização de princípios constitucionais como referência ao exercício do controle jurisdicional. Para tanto, valem-se de conceitos tais quais o de razoabilidade, interesse público, eficiência.

Nesse contexto, confiram-se precedentes judiciais que ilustram tais linhas argumentativas e informam a possibilidade de controle judicial de atos regulatórios à luz dos princípios citados, ora indicando tratar-se de controle de legalidade, ora, de controle de mérito ${ }^{31}$

CONSTITUCIONAL, ADMINISTRATIVO E PROCESSUAL CIVIL. APELAÇÃO EM AÇÃO CIVIL PÚBLICA. REVISÃO DA TARIFA DE ENERGIA ELÉTRICA DA CELPE. CONTROLE JURISDICIONAL DA LEGALIDADE DOS ATOS DE CONCESSIONÁRIAS DE SERVIÇOS PÚBLICOS. PRINCÍPIOS CONSTITUCIONAIS DA MODICIDADE DAS TARIFAS E DA TUTELA DOS INTERESSES DOS CONSUMIDORES.

1. Os atos da ANEEL sujeitam-se ao controle jurisdicional, sobretudo em sede de ação civil pública que versa a política tarifária de setor fundamental para o desenvolvimento nacional e o bem-estar da população.

2. O indeferimento de prova testemunhal desnecessária não caracteriza cerceamento de defesa.

3. As perdas de energia computadas pela ANEEL nas resoluções que homologaram a revisão tarifária de 2005 e o reajuste de 2006, referentes à CELPE, não são indicativas do repasse ao consumidor da ineficiência da empresa, nem implicaram violação os princípios da razoabilidade e da modicidade tarifária.

4. Apelação não provida.

\footnotetext{
${ }^{30}$ No ponto, nota-se a interlocução do entendimento com a proposta norte-americana de deferência, ou selfrestraint, do órgão jurisdicional em face da atuação dos órgãos reguladores. Segundo a doutrina consagrada no caso Chevron USA Inc. v. Natural Resources Defense Council (1984) o Poder Judiciário possui competência para determinar a invalidade ou a revisão de um ato das agências reguladoras tão-somente quando o Congresso houver tratado da matéria de forma clara e contrária ao entendimento adotado pela autoridade reguladora. Em caso de dúvidas relacionadas à decisão parlamentar, o Judiciário deve avaliar a razoabilidade do ato praticado pela agência e decretar sua anulação se esse ato for arbitrário ou caprichoso (BRUNA, 2003, p 240249).

${ }^{31}$ Além dos precedentes citados, confira-se ainda STJ, REsp. 429.570/GO, Segunda Turma, Rel. Min. Eliana Calmon, DJ de 22/03/2004, p. 277, RSTJ, p. 219
} 
(TRF 5a Região, AC n. 457.088/PE - 2006.83.00.012127-9, Quarta

Turma, Rel. Des. Marcelo Navarro, julgado em 17.03.2009)

AGRAVO DE INSTRUMENTO EM AÇÃO CAUTELAR INTERPOSTO PELO MINISTÉRIO PÚBLICO FEDERL (MPF) - AGÊNCIA NACIONAL DE TELECOMUNICAÇÕES (ANATEL) - PODER DE POLÍCIA - CANAL DE TELEVISÃO COMUNITÁRIO - SANÇÃO ADMINISTRATIVA DE INTERRUPÇÃO DO SINAL DE TV POSSIBILIDADE DO PODER JỦDICIÁRIO ADENTRAR AO MÉRITO ADMINISTRATIVO - PRINCÍPIO DA PROPORCIONALIDADE

(...) IV - Ora, não existe a menor dúvida de que a ANATEL, constituída na forma de Autarquia de Regime Especial, tem a prerrogativa de se valer do Poder de Polícia conferido à Administração Pública em geral para atingir efetivamente o seu escopo de fiscalizar e coibir infrações cometidas em ofensa às regras pertinentes ao serviço de telecomunicações, a teor do precitado art. 19, da Lei n. 9 9.472/97.

V - A impossibilidade do Poder Judiciário de se imiscuir no mérito administrativo encontra-se, na atual dogmática do Direito Administrativo, um tanto rarefeito, haja vista algumas exceções qualitativamente importantes, geradas no âmbito do póspositivismo e da normatividade dos princípios. Diante desta nova realidade, podemos dizer que princípios com reflexos importantes no direito administrativo, dentre os quais os da razoabilidade, da moralidade e da eficiência, têm permeado e possibilitado ao Judiciário adentrar no mérito administrativo, o que deve ser feito de forma excepcional, ou seja, diante da certeza da manifesta irrazoabilidade ou inobservância da aplicação das normas que regem os atos administrativos.

VI - Entendo, na esteira da decisão interlocutória, que a imposição de penalidade mais grave (interrupção da veiculação do canal), quando da existência de outra menos gravosa (multa, por exemplo) e suficiente para se atender, ao menos em tese, ao fim que se destina, vai de encontro ao princípio da proporcionalidade (subprincípio da necessidade), que impõe ao Poder Público a verificação da existência de meio menos gravoso para atingimento dos fins colimados.

VII - Por outro lado, o custo-benefício, que é a ponderação entre os danos causados e os resultados obtidos, tem que se pautar em uma justificável interferência na esfera alheia, o que não se verifica no caso, pois não é minimamente admissível impedir aos munícipes de Nova Friburgo o acesso aos programas culturais somente pelo fato da TVC 6 estar veiculando comerciais, seria como, mal comparando, curar a doença, matando o doente.

VIII -Recurso do Ministério Público Federal improvido. (TRF 2a Região, Ag. Inst. n. 159.351/RJ, Sétima Turma Especializada, Rel. Des. Reis Friede, julgado em 02.07.2008, DJU de 09.07.2008, p. 115)

ARAGÃO (2009) também recorre aos princípios da razoabilidade e proporcionalidade, mas vai além do que sustentam DI PIETRO e BARROSO, para 
os quais cabe ao Judiciário apenas anular as decisões regulatórias que violem a lei ou os aludidos princípios, mas não substituir tais decisões.

O autor defende que em casos concretos nos quais os autos e a norma discricionária a ser aplicada ofereçam uma solução razoável, o Poder Judiciário não deverá se furtar de aplicá-la. Em outras palavras, ARAGÃO entende que o Poder Judiciário só poderá suprir, em caso de omissão, ou substituir, em caso de anulação, o exercício da atividade discricionária das agências reguladoras nos casos concretos em que existirem elementos objetivos suficientes para que, do conjunto dos dados normativos e fáticos disponíveis, se possa extrair uma - e apenas uma - solução legítima (2009, p. 353).

O autor destaca, contudo, que em face à ampla discricionariedade conferida pela lei e ao caráter técnico-especializado do seu exercício, prevalece, na dúvida, a decisão do órgão ou entidade reguladora. Segundo o autor, isso decorre da natureza da matéria, que deixaria de ser decidida pela agência, para, na prática, passar a ser decidida pelo perito técnico do Judiciário (2009, p. 350-351).

Por sua vez, FERRAZ JÚNIOR (2008) comunga do entendimento de que o Judiciário deva realizar um controle de mérito dos atos das agências reguladoras. Entretanto, o cerne da argumentação expendida pelo autor é a observância do princípio da eficiência. Esse princípio criaria para as agências a responsabilidade pelos resultados, ou responsabilidade eficiente. Nesse contexto, sustenta o autor:

Em suma, o poder regulador das agências encontra limites no princípio da eficiência, o que faz com o que o seu controle seja exercido sobre a razoabilidade de seu conteúdo. Nos termos de uma exigência de eficiência, o controle de razoabilidade desdobra-se em três itens, a saber, adequação com relação aos fins propostos (adequação), êxito dos meios escolhidos para alcançar os resultados (êxito) e proporcionalidade dos meios com relação aos ônus impostos aos administrados, i.e., gerar os ganhos pretendidos com o mínimo de custos sociais (proporcionalidade).

Ocorre que, na prática, a problemática do controle judicial de atos regulatórios não se reduz à aplicação de princípios. Em outras palavras, notadamente quando a questão envolve questões técnicas complexas, não se afigura evidente a verificação da razoabilidade, proporcionalidade ou eficiência da decisão impugnada. Por vezes, a aplicação desses princípios implicará na substituição do juízo discricionário da agente regulador pelo do magistrado, já que tal apreciação não é de todo objetiva. Como salientado por SHAPIRO (1988, p. 2): 
when judges decide about the lawfulness or justness of administrative agency decisions, questions of right and good become inextricably tangled with questions of law and justice.

Por outro lado, socorrer-se da existência de um interesse público a ser observado parece também não resolver a questão. Primeiro porque a expressão não possui significado preciso ${ }^{32}$. De fato, apesar do esforço doutrinário em definir seu conteúdo, entende-se inexistir método objetivo de definição do que seja o interesse público (SHAPIRO, 1988, p. 5) ${ }^{33}$. Em verdade, como tratado anteriormente, a regulação envolve interlocução com os diversos interesses enredados na atividade regulada (MARQUES NETO, 2002, p. 207), razão pela qual não se admite a existência de um único interesse público a ser atendido. Nas palavras de ARAGÃO (2009, p. 292):

As decisões das agências reguladoras dever-se-ão pautar-se por critérios ponderados de exercício da discricionariedade muito mais complexos do que uma ultrapassada "supremacia do interesse público": há diversos interesses públicos, alguns contraditórios entre si; há interesses de várias categorias de consumidores; os interesses das empresas reguladas podem ser antinômicos, etc.

Em segundo lugar, uma vez que não há como se falar abstratamente em interesse público, exorbita as competências do Judiciário a definição de que interesse deva ser perseguido pelas agências reguladoras. No ponto, questiona-se,

\footnotetext{
${ }^{32}$ Tratado de um modo propositalmente vago e ambíguo, o interesse público acaba funcionando como uma espécie de caixa de ressonância dos diferentes valores e interesses de cada membro da sociedade, por mais que eles sejam entre si colidentes e conflitantes. Trata-se de uma estratégia sutil por meio do qual a ordem jurídica se apresenta como segura e elástica, justa e compassiva, socialmente eficaz e moralmente eqüitativa, digna e solene, mas sempre técnica e funcional - o que permite ao direito positivo assegurar a ordem em contextos sociais complexos e heterogêneos, equilibrando de modo casuístico, conforme as circunstâncias do momento histórico, a intrincada gama de relações entre o individual e o coletivo, entre o proibido e o permitido, entre a liberdade de cada cidadão e as exigências de natureza comum. (...) $O$ recurso a lugarescomuns abertos e indeterminados como o conceito de interesse público acarreta a um só tempo a consagração formal dos mais variados direitos e o não cumprimento de muitos deles na prática; os antagonismos podem então ser vistos como sempre provisórios, pois seriam sempre passiveis de uma decisão "técnica" (FARIA, 1992, 175-176).

${ }^{33}$ Shapiro (1988, p. 5): "They [the political theorists who propounded pluralist or polyarchical views] did argue, however, that there was no universally accepted logical or scientific procedure for determining the good and relatively little consensus on what the good was. Each group would have its own necessarily incomplete and somewhat distorted vision of the public good. Given these realities, and as a second-best solution in the absence of universally agreed right policies, the pluralists were driven toward a proceduralist criterion as a working standard for public policy. Those public policies were to be considered correct that were arrived at by a process in which all relevant groups had actively participated, each with enough political clout to insure that its views had to be taken into account by the ultimate decision makers".
} 
inclusive, a legitimidade de uma atuação dessa envergadura ${ }^{34}$. A esse respeito, SHAPIRO (1988, p. 173) adverte:

the judge as senior prudent leads us back to a far more acute form of the 'mighty problem' of judicial review, its undemocratic character, than does the judge as senior technocrat.

Além disso, embora o exame de legalidade ainda seja uma forma de controle judicial da atuação regulatória ${ }^{35}$, entende-se que esse controle não deve se esgotar apenas nessa dimensão. Como apontado no capítulo inicial, há uma tendência de que a lei se limite a fixar parâmetros extremamente abertos, em razão da complexidade das atividades reguladas, que exige muitas vezes um regramento altamente técnico e sujeito a alterações constantes, dificilmente obtido pela via legislativa (JUST, 2009) ${ }^{36}$. Nessa esteira, reduzir o controle judicial ao controle de legalidade e, assim, à observância de tais parâmetros, significa anular a efetividade do controle judicial ${ }^{37}$.

Por todo o exposto, é possível afirmar que as diferentes linhas doutrinárias desenvolvidas no Brasil sobre o controle jurisdicional de atos regulatórios parecem restringir-se a uma análise formalista da dogmática jurídica ${ }^{38}$. Como salientado por MATTOS (2006, p. 354), quando o Judiciário é chamado a se manifestar sobre a constitucionalidade ou a legalidade das políticas públicas definidas pelo Poder Executivo, em geral duas situações ocorrem:

\footnotetext{
${ }^{34}$ Por outro lado, conforme sustentado no segundo capítulo, entende-se que as agências reguladoras gozam de legitimidade democrática em sua atuação.

${ }^{35}$ Segundo BRUNA (2003, p. 266), a análise dos procedimentos decisórios como forma de avaliar a validade dos atos normativos não significa que se possa abdicar da avaliação dos limites materiais estabelecidos pela lei e, de forma geral, pelo ordenamento jurídico, para o exercício de função administrativa.

${ }^{36}$ No ponto, vale citar o entendimento de BRUNA (2003, p. 140), segundo o qual para que os regulamentos editados por agências reguladoras não firam as exigências de legalidade estabelecidas no texto constitucional, é imperioso que a lei atribuidora de competências normativas a autoridades administrativas preestabeleça as diretrizes para o exercício de tais competências, prescrevendo a natureza e os limites dos poderes conferidos, bem como as finalidades a atingir, desse modo fixando parâmetros suficientes para viabilizar o controle jurídico do exercício dos poderes atribuídos.

${ }^{37} \mathrm{O}$ controle de legalidade nesses termos fundamenta-se, segundo MATTOS (2006, p. 359), em uma concepção de legitimidade que tem por base uma racionalidade jurídica tipicamente lógico-formal. Ou seja, basta que a norma de conjuntura ou a política pública definida pelo Poder Executivo estejam logicamente adequados aos objetivos, diretrizes, e prioridades definidos no texto constitucional e aprovados em lei pelo Poder Legislativo, que tal norma ou tal política reputar-se-ão legítimas. É, assim, um conceito de legitimidade restrito a juízos formais de legalidade. (...) é um conceito limitado para garantir, no plano do sistema jurídico, que princípios constitucionais, normas programáticas, objetivos, diretrizes, e prioridades sejam a bases de processos deliberativos democráticos sobre o conteúdo da regulação.

${ }^{38}$ Não se nega a relevância da dogmática jurídica para o debate, entretanto, as argumentações desenvolvidas parecem ser insuficientes para um controle judicial efetivo.
} 
(i) ou o Judiciário não julga o mérito das políticas em questão, alegando que se trata de exercício de poder discricionário da Administração, (ii) ou o Judiciário julga o mérito e (a) declara, por meio de juízo de legalidade estritamente formal, a ilegalidade do conteúdo normativo em face dos princípios e normas programáticas previstos no texto constitucional ou em lei, ou (b) declara - ainda com base em juízo formal - a sua legalidade em face do princípio da supremacia do interesse público sobre o interesse privado.

Desse modo, segundo o autor, ou há um controle fraco de atos regulatórios discricionários (sem controle de mérito quando se trata de juízo de conveniência ou oportunidade), ou um controle meramente formal de legalidade das normas de conjuntura editadas pelas agências reguladoras; ou ainda, não há, na prática, controle algum (MATTOS, 2006, p. 358) ${ }^{39}$. Nessa linha, entende-se que reduzir o controle judicial a um mero controle de legalidade significa limitá-lo ao exame de formalidades e, assim, torná-lo inócuo a arbitrariedades. Por esse prisma, não deve o Judiciário se furtar a realizar um controle de mérito sob o argumento de que a decisão foi concebida a partir do exercício de discricionariedade técnica própria às agências reguladoras. Como se verá a seguir, a própria noção de discricionariedade técnica é passível de questionamentos.

\subsection{O dogma da discricionariedade técnica das agências reguladoras}

O debate sobre o controle judicial de atos regulatórios, tal como o debate a respeito de atos administrativos de modo geral, acabam tocando, de algum modo, a questão da discricionariedade administrativa. No particular dos atos emanados de agências reguladoras, recorrentemente alega-se a existência de discricionariedade técnica. Há divergências, entretanto, quanto à possibilidade de revisão ou mesmo quanto ao conteúdo dessa discricionariedade. Nesse contexto, interessa a este estudo analisar os diferentes posicionamentos a respeito do tema.

Segundo JUSTEN FILHO (2002, p. 516), a discricionariedade é a solução jurídica para as limitações e defeitos do processo legislativo de geração de normas jurídicas. Nessa linha, o autor entende ser da essência da discricionariedade que a

\footnotetext{
${ }^{39}$ CINTRA (apud VERISSIMO, p. 407) define a situação nos seguintes termos: De um modo geral, pode-se dizer que o Poder Judiciário, no Brasil, aprecia as questões de legalidade, mas não reexamina o mérito do ato administrativo, isto é, a sua oportunidade e conveniência, que se incluem na competência exclusiva do administrador. Este quadro, no entanto, está longe de esgotar a riqueza e complexidade da matéria.
} 
autoridade defina a melhor solução possível, adote a disciplina mais satisfatória e conveniente ao interesse público.

Por sua vez, MELLO (2008, p. 428-429) compreende que a discricionariedade existe, por definição, única e tão-somente para proporcionar em cada caso a escolha da providência ótima, ou seja, daquela que realize superiormente o interesse público almejado pela lei aplicanda.

Para o autor, haverá casos em que pessoas sensatas, equilibradas, normais, serão todas concordes em que só um dado ato - e não outro - atenderia à finalidade da lei invocada; ou assentirão apenas em que, de todo modo, determinado ato, com certeza objetiva, não a atenderia. Em tais hipóteses, se a Administração agir de forma diversa, evidentemente terá descumprido a finalidade legal. Nesses casos, caberia ao Judiciário, mediante provocação, invalidar o ato eivado dos vícios apontados.

Como se observa das definições propostas pelos autores, a idéia de discricionariedade envolve conceitos abertos tais quais sensatez, conveniência e interesse público e finalidade legal. Assim, embora se reconheça um esforço doutrinário em definir limites à discricionariedade do administrador, o que se verifica, na prática, é a utilização de termos não menos abertos e subjetivos do que a própria noção de discricionariedade.

MATTOS (2006) relaciona a dificuldade da doutrina e jurisprudência em lidar com o conceito de discricionariedade aos entraves para a realização de um controle judicial efetivo. Segundo o autor o dogma da discricionariedade administrativa e o lugar comum retórico que o conceito de interesse público possui em significativa parcela da doutrina brasileira impedem que o Judiciário exerça controle sobre o exercício de capacidade normativa de conjuntura por parte da Administração.

De fato, como aponta MORÓN (1994, p. 114), o juízo discricionário não se restringe a critérios meramente jurídicos, mas envolve critérios políticos, técnicos, juízos de conveniência e oportunidade:

la discrecionalidad comporta, como se reconece por doquier, la necesidad de tomar en cuenta criterios no estrictamente jurídicos para adoptar la decisión, es decir, critérios políticos, técnicos o de mera oportunidad o conveniencia (económica, social, organizativa) según los casos. Criterios que han de utilizarse bien para adoptar una iniciativa de gobierno o de gestión, bien para aplicar una diretriz legal imprecisa, bien para valorar una situación de hecho para la que 
la ley dispone una cierta consecuencia, bien para optar entre unas $u$ otras soluciones posibles cuando la tarea de gobernar o de administrar impone tomar uma decisión.

(...)

El ejercicio de la potestad discrecional no es, pues, um mero proceso intelectivo de aplicación de la ley (y del derecho), es decir, un proceso lógico íntegramente guiado o dominado por el razoniamento jurídico, sino que es también, al mismo tiempo, un proceso volitivo de decisión que ha de tener en cuenta otros elementos.

Os múltiplos critérios que envolvem a tomada de decisão pela Administração Pública se projetam no controle judicial dos atos administrativos. Segundo ENTERRÍA (2000, p. 455), a existência de poderes discricionários constitui por si mesma, um desafio às exigências da justiça. Nas palavras do autor:

la existencia de potestades discricionales constituye por si misma un deasfío a las exigencias de la justicia, ¿porqué? Cómo controlar la regularidad y la objetividad de las apreciaciones subjetivas de la Administración, cómo evitar que invocando esa libertad estimativa se agravie em el caso de la equidad, cómo impedir que la libertad de apreciación no pare en arbitrariedad pura y simple?

Nesse contexto, há doutrinadores que entendem que, no caso das agências reguladoras, haveria uma modalidade específica de discricionariedade: a discricionariedade técnica. A partir do pressuposto de que, em tais casos, a decisão teria fundamentos estritamente técnicos, alguns autores concluem que o controle judicial possuiria limites ainda mais estreitos. A esse respeito, confira-se 0 entendimento de AMARAL (2008, p. 85):

A discricionariedade na atividade regulatória não é política, mas essencialmente técnica. Disto decorre que seu controle não pode envolver o mérito, pois o seu conteúdo é de cunho científico. Porém, cabe ao Judiciário o exame da coerência lógica na motivação científica, técnica ou de experiência constante na decisão reguladora, abrangendo, assim, a verificação dos fatos e a adequada valoração.

Na mesma linha, SOUTO (2002, p. 359) entende ser inadmissível o controle de mérito da discricionariedade técnica, salvo por erro de fato, irrazoabilidade de contradição (que seria excesso de poder) ou violação da lei. Para o autor, a submissão de decisões de agências reguladoras aos magistrados diminuir-Ihes-ia a força e a eficácia. Sob essa perspectiva, sugere que o ideal seria introduzir a limitação da Lei n. 9.307, de 23 de setembro de 1996, Lei de Arbitragem, para somente admitir o questionamento judicial em caso de vícios formais nas decisões, respeitando-se as situações em que houver direitos indisponíveis do Estado (SOUTO apud CALIL, 2006, p. 152). 
Para outros autores, como DI PIETRO (2002, p. 156) é justamente a natureza técnica da decisão regulatória que justifica a possibilidade de controle judicial. Segundo a autora, não há fundamento para a reserva de uma discricionariedade técnica para as agências. Embora reconheça que órgãos reguladores, em função de sua especialidade, possam estabelecer normas sobre aspectos técnicos da matéria que lhes é afeta, a autora entende que não se deve, desde logo, excluir esses aspectos do controle judicial.

Isso porque, na medida em que se reconhece, sem qualquer controvérsia, a possibilidade de o Judiciário examinar matéria de fato, por mais técnica que seja (e o faz, em regra, com a ajuda de peritos), e na medida em que são perfeitamente possíveis o abuso de poder, o arbítrio, o erro, o dolo, a culpa, no estabelecimento de critérios técnicos, também não se pode deixar de reconhecer que a chamada discricionariedade técnica possa causar lesão ou ameaça de lesão e, portanto, ensejar a correção judicial.

Nessa esteira, DI PIETRO (2002, p. 156) sustenta que, entre os conceitos jurídicos indeterminados contidos na lei, os conceitos técnicos são precisamente os que menos geram discricionariedade, pelo simples fato de que a indeterminação pode desaparecer com a manifestação do órgão técnico (...). Segundo a autora, no Direito brasileiro, os peritos são considerados auxiliares da Justiça e, com sua manifestação, o Judiciário pode transformar em determinado um conceito que, na lei, aparece como indeterminado.

Ainda quanto à discricionariedade técnica e, na mesma linha que DI PIETRO, CALIL $(2006,155)$ defende que o grau de subjetivismo de que dispõe o agente regulador é muitíssimo reduzido, ou não mereceria a alcunha de "técnica". Portanto, a referida discricionariedade não poderia servir para abrir uma brecha à arbitrariedade administrativa sem controle jurisdicional.

Ambos os entendimentos, quer para defender, quer para afastar 0 controle judicial de mérito, partem da premissa de que as decisões prolatadas por agências reguladoras sejam técnicas. No ponto, deve-se salientar que inexiste decisão puramente técnica. Ainda que tais decisões devam pautar-se por critérios técnicos, sempre haverá margem para a subjetividade.

Como salientado por ARAGÃO (2009, p. 324), tecnicidade não significa imparcialidade, já que, salvo em casos limites, o saber técnico pode perfeitamente ser intrumentalizado em favor de diversos interesses políticos. No mesmo sentido, 
JUSTEN FILHO (2002, p. 527) observa que a defesa da autonomia do instituto da discricionariedade técnica reflete uma certa concepção positivista de ciência, incompatível com a realidade contemporânea.

Nessa linha, BACHELET (apud DAROCA, 1997, p. 49) expõe o seguinte:

A técnica não é capaz de proporcionar soluções unívocas a determinados problemas, razão pela qual sempre existe uma margem de elasticidade dentro da qual a Administração tem que escolher diferentes soluções proporcionadas pela técnica, o que deverá ser feito com critérios não técnicos (...), havendo um momento claramente político nestas escolhas. Isto se põe de forma mais manifesta em determinados conhecimentos científicos, como a ciência da economia e das finanças, em que as construções e princípios de atuação se encontram claramente impregnados por critérios de valor e, portanto, políticos.

Não se pretende aqui negar a existência de decisões de ordem técnica. De fato, as agências reguladoras se pautam (ou devem se pautar) também em conhecimentos técnicos para exarar uma decisão, seja esta específica para um determinado caso ou geral e abstrata, no exercício do poder regulamentar. O que se questiona é a pretensão de conferir neutralidade a essas decisões. Ocultar critérios políticos que ensejaram uma decisão sob o manto da tecnicidade pode gerar conseqüências danosas ao sistema regulado.

MOREIRA (2003, p. 251) ironiza o emprego da expressão discricionariedade técnica, salientando que se trata de uma locução quase mágica, que simultaneamente pretende legitimar a decisão (emitida de forma neutra por um técnico com conhecimentos extraordinários) e eliminar o controle jurisdicional (o Judiciário não disporia do conhecimento sofisticado que possibilitasse o controle).

Veja-se que mesmo supondo ser possível que uma decisão se ampare em fundamentos tão-somente técnicos, a avaliação de que técnica é mais adequada a um determinado caso não será de todo objetiva. Isto é, não se ignora a possibilidade de que, para dada situação, exista mais de uma decisão técnica possível.

A esse respeito, GUERRA (2004, p. 13) teceu as seguintes considerações:

(...) à luz da ampla classificação doutrinária sobre o tema, entendemos que inexiste inserida nessas competências uma discricionariedade estritamente técnica, como espécie do gênero discricionariedade administrativa stricto sensu ou pura, ainda que se cogite que a entidade reguladora independente somente exerce 0 seu múnus público com arrimo em conhecimentos técnicos (e não políticos) para decidir diante do caso concreto. 
Ao nosso ver, ao integrar uma norma (seja por sua propositada abertura ou pela existência de conceitos jurídicos indeterminados), se a entidade reguladora identificar vários meios igualmente eficazes para a consecução do fim público no caso concreto, resta indisputável que deverá selecionar um deles que entenda mais oportuno e conveniente para o seguimento regulado e, por conseguinte, o interesse geral.

(...)

Esse posicionamento crítico parte da premissa de que, salvo em raríssimas exceções, os métodos científicos não proporcionam verdades absolutas.

No mesmo sentido, JUSTEN FILHO (2006) anota que a atividade regulatória, ainda quando envolva escolhas de natureza técnico-científica, abrange decisões políticas relacionadas à conveniência e à oportunidade. Segundo o autor, $O$ próprio conceito de regulação econômica incorpora essa opção governamental por uma dentre diferentes alternativas. Não se trata, portanto, de uma atuação vinculada estritamente à lei ou ao conhecimento técnico-científico, os quais não fornecem todos os critérios decisórios.

Assim é que se faz coro ao entendimento de PEREIRA (2003, p. 261), para quem o emprego da expressão discricionariedade técnica é fonte de uma série de equívocos. Segundo o autor, ela faz supor que (a) todos os juízos técnicos da Administração são insindicáveis pelo Poder Judiciário por serem discricionários, ou que (b) há uma espécie de discricionariedade que não se submete ao mesmo regime da discricionariedade administrativa ou, ainda, que (c), pela reação que provoca, todas as atividades administrativas relacionadas com questões técnicas são vinculadas e excluem a discrição.

Desse modo, entende-se que não deve o Judiciário evadir-se de examinar o mérito da decisão regulatória impugnada judicialmente sob o argumento de que se trata de seara sujeita à discricionariedade técnica das agências.

Ocorre que, se por um lado o mero controle de legalidade é insuficiente, por não permitir que se aprecie o conteúdo da decisão, por outro, a definição pelo magistrado de que decisão é mais razoável ou adequada ao caso parece significar a substituição da discricionariedade do regulador pela do juiz.

Como anteriormente exposto, embora significativa parte da doutrina encerre a discussão sugerindo a aplicação dos princípios da razoabilidade, proporcionalidade ou eficiência pelo Judiciário, entende-se que também os 
parâmetros para definir o que seria uma decisão razoável, proporcional, ou mesmo uma decisão ótima são relativos e envolvem critérios subjetivos.

Como acentuado por CHEVALLIER (apud JUSTEN FILHO, 2006), nem mesmo os métodos mais sofisticados jamais permitirão a supressão dos elementos irredutíveis de irracionalidade, que se relacionam tanto ao contexto, ao sujeito que decide e ao ambiente em que ele se encontra, mas também e, sobretudo, à existência em todo processo decisório de racionalidades divergentes ${ }^{40}$ resultando em recusa à própria idéia de escolha ótima. Para o autor, toda política é o resultado contingente de uma arbitragem entre uma série de imperativos contraditórios.

Assim, conquanto se constate que o mérito dos atos regulatórios não se reduz a apreciações técnicas e que, portanto, deve ser submetido ao crivo do Judiciário, de modo a coibir e combater arbitrariedades observa-se que também a atuação do Judiciário se sujeita a limites, para que não faça as vezes das agências reguladoras. Com efeito, a substituição das autoridades reguladoras pelos juízes é uma questão constantemente suscitada pela doutrina e jurisprudência e seus desdobramentos serão analisados ao passo seguinte.

\subsection{Substituição de atos regulatórios por decisões judiciais}

A preocupação de que o controle judicial não implique a nulificação da competência regulatória, com a substituição da discricionariedade das agências reguladoras pela do Judiciário, tem sido um tema recorrente na doutrina. Ao tratar da revisão judicial de decisões emanadas de agências reguladoras, MOREIRA (2006, p. 219) ressalva:

À evidencia, não se está a defender uma sucessão de discricionariedades: o juiz atua como 'administrador negativo' (ou 'regulador negativo'), vedando os excessos e os abusos porventura cometidos. Não se pretende a substituição de uma decisão eventualmente qualificada pela discricionariedade oriunda da agência por decisões discricionárias do Judiciário. O núcleo duro da discricionariedade permanece intacto (seja ela técnica ou não).

\footnotetext{
${ }^{40}$ A existência de racionalidades divergentes não implica admitir que a decisão discricionária seja irracional. Segundo ENGISCH (apud BRUNA, 2003, p. 126-127), a decisão discricionária deve ser axiológica e teleologicamente articulada, isto é, necessita estar amparada em um quadro lógico, cujos valores e fins a que respeite sejam expostos, ainda que subsista sempre a coloração pessoal das valorações materiais e da decisão da vontade.
} 
Embora não seja possível definir abstratamente o conteúdo desse núcleo duro mencionado por MOREIRA, parece ser consensual que a atuação judicial está sujeita a limites. Sobre o assunto, GARCÍA (apud GUERRA, 2010) pondera o seguinte:

si admitimos que la discrecionalidad era el caballo de Troya del Estado de Derecho (...) hay que admitir también que el control judicial de tales actos es el caballo de Troya del decisionismo judicial en la actividad política y estrictamente administrativa, que en cualquier Estado está confiada a los políticos y a los administradores, no a los jueces.

No ponto, deve-se registrar o posicionamento de G. MORAES (1999, p. 155-156), para quem o Poder Judiciário, ao rever os atos administrativos não vinculados, pode invalidá-los, mas não pode, em regra, determinar sua substituição por outros. Segundo a autora, em certas situações excepcionais, é possível ao magistrado inferir, da realidade e da ordem jurídica, qual a única decisão comportável pelo Direito para solucionar o caso.

$\mathrm{Na}$ mesma linha, como anteriormente exposto, ARAGÃO (2009, p. 353) entende que o Judiciário pode substituir a decisão das agências reguladoras, ou suprir sua omissão em casos concretos nos quais os autos e a norma discricionária a ser aplicada ofereçam uma solução razoável. Ainda assim, de acordo com o autor, essa forma de atuação do Judiciário está sujeita a limites. Isso porque se restringe a casos concretos em que existam elementos objetivos suficientes para que, do conjunto dos dados normativos e fáticos disponíveis, se possa extrair uma e apenas uma - solução legítima (2009, p. 353).

Tal entendimento, contudo, não subsiste quando se observa que, como antes defendido, a tomada de decisões pelas agências reguladoras não se pauta exclusivamente em critérios técnicos objetivos. Nesse contexto, falar em única decisão comportável pelo Direito, ou ainda, em única solução razoável, pode dar azo à substituição da discricionariedade do órgão regulador pela do juiz.

Segundo JUSTEN FILHO (2006), se não houvesse limites à revisibilidade jurisdicional, se tornaria inútil a própria existência das agências reguladoras. Se todas as respostas fossem fornecidas pela Lei, pela Ciência e pela Técnica, a existência de agências seria dispensável. Suas decisões deixariam de apresentar qualquer cunho de discricionariedade e, assim, caberia à Administração Pública o exercício de suas competências e ao Judiciário a revisão de todas as decisões. 
Nessa linha, o autor sustenta não ser cabível que o Judiciário substitua as escolhas realizadas pelas agências por outras, resultantes da avaliação pessoal do juiz.

Nada obsta, entretanto, a invalidação de atos defeituosos em face de competências mal exercidas. Para JUSTEN FILHO (2002, p. 590-592), essa forma de atuação não importa infração ao princípio da separação dos poderes. O que não se admite é a produção de norma geral e abstrata substitutiva daquela editada invalidamente pela agência.

Por essa razão, o autor sustenta que o controle jurisdicional de atos dotados dessas características deverá ser realizado com a cautela correspondente e define os seguintes limites:
A decisão judicial terá de recorrer à manifestação da opinião de especialistas de notória especialização, com a advertência da impossibilidade de o Judiciário substituir-se à autoridade administrativa no tocante ao exercício de escolhas discricionárias. Ou seja e quando muito, poderá apontar-se a incorreção técnico-científica da decisão adotada pela agência ou a impossibilidade da justificação de sua adoção em face do conhecimento especializado ou das premissas consagradas na própria atuação anterior da agência (inclusive no tocante à fixação de políticas públicas por ela consagradas). Verificada a compatibilidade da decisão com o conhecimento técnico-científico, será vedado ao Judiciário reprovar o ato em virtude de uma avaliação igualmente subjetiva acerca da melhor solução a adotar no caso concreto. (JUSTEN FILHO, 2002, p. 592)

Para WIMMER (2008, p. 4), a atuação do Judiciário não se confunde com a das agências reguladoras, dado que o poder próprio da Administração manifestase precisamente no exercício da discricionariedade e da prerrogativa de avaliação respeitante ao preenchimento de conceitos jurídicos indeterminados. Segundo a autora, através destas figuras, o ordenamento jurídico recusa a subordinação total das agências reguladoras ao juiz, porque a este não caberá substituir-se à Administração para efeito de refazer os juízos valorativos de prognose e de ponderação de interesses em conflito, isto é, não lhe cabe rever e emitir em última instância juízos de mérito que integram materialmente a função administrativa $e$, em princípio, se encontram arredados do controle jurisdicional de legalidade.

Embora não se coadune com a premissa adotada pela autora, segundo a qual o controle judicial se restringiria a um controle de legalidade, parece acertado o entendimento de que não compete ao Judiciário decidir em substituição às agências reguladoras. Como ressaltado por SOUTO (2002, p. 359), a amplitude do exame 
judicial não autoriza a substituição da opção do administrador e, em especial, do agente regulador, pela do juiz.

Por esse prisma, caso o Judiciário anule uma decisão regulatória discricionária, o magistrado deverá devolver o assunto à agência reguladora para que exare outra decisão, levando em consideração todos os aspectos apontados pelo órgão judicial (GUERRA, 2010). De modo análogo, constatada a omissão indevida do ente regulador, pode o Judiciário fixar prazo para que a agência se manifeste, mas não decidir em seu lugar.

Conforme se observa das ementas a seguir, relativas a acórdãos do STJ, a jurisprudência tem oscilado quanto aos limites de atuação do Poder Judiciário, quando verificadas falhas na regulação.

ADMINISTRATIVO. RECURSO ESPECIAL. MANDADO DE SEGURANÇA. AUTORIZAÇAO PARA FUNCIONAMENTO DE RÁDIO COMUNITÁRIA. INÉRCIA DA ADMINISTRAÇAO PÚBLICA. ABUSO DO PODER DISCRICIONÁRIO.

1. Não se conhece da suposta afronta ao artigo 535 do CPC, quando o acórdão recorrido examinou, motivadamente, todas as questões pertinentes ao desfecho da lide, apenas não adotando a tese sustentada pelo recorrente.

2. A autorização do Poder Executivo é indispensável para o regular funcionamento de emissora de radiodifusão, consoante o disposto nas Leis 4.117/62 e 9.612/98 e no Decreto 2.615/98 e nos termos do entendimento pacífico nesta Corte. Entretanto, em obediência aos princípios da eficiência e razoabilidade, merece confirmação o acórdão que julga procedente pedido para que a Anatel se abstenha de impedir o funcionamento provisório dos serviços de radiodifusão, até que seja decidido o pleito administrativo da recorrida que, tendo cumprido as formalidades legais exigidas, espera desde 2005 sem que tenha obtido uma simples resposta da Administração.

3. Recursos especiais não providos.

(STJ, REsp n. 1.100.057/RS - 2008/0236004-2, Primeira Turma, Rel. Min. Benedito Gonçalves, julgado em 19/05/2009)

ADMINISTRATIVO. RÁDIO COMUNITÁRIA. PRESTAÇÃO DE SERVIÇO. PEDIDO DEAUTORIZAÇÃO. CONCESSÃO PELO PODER JUDICIÁRIO. IMPOSSIBILIDADE.

1. A controvérsia cinge-se em saber se há possibilidade ou não de o Poder Judiciário autorizar o exercício precário do serviço de radiodifusão comunitária, até que a Administração decida definitivamente a questão.

2. O procedimento administrativo, que tem por objeto verificar os requisitos da Lei $n^{\circ}$ 9.612/98 e do Decreto 2.615/98, não pode ser substituído por provimento jurisdicional que autorize 0 funcionamento da rádio, já que não compete ao Poder Judiciário adentrar no mérito do ato administrativo.

3. Constatado atraso injustificado no exame do pedido de autorização para funcionamento de rádio comunitária, o órgão 
jurisdicional pode fixar prazo razoável para que a mora administrativa seja sanada, desde que, é claro, exista pedido na inicial nesse sentido. $\mathrm{Na}$ espécie, não houve requerimento, o que inviabiliza tal solução. Precedentes: EREsp 1.100.057/RS, Rel. Min. Eliana Calmon, DJe de10.11.09; EDcl no AgRg no Ag 1.161.445/RS, Rel. Min. Mauro CampbellMarques, DJe de 24.08.10; REsp 1.019.317/MG, Rel. Min. Castro Meira,DJe de 11.11.09; REsp 1.006.191/PI, Rel. p/ Acórdão Min. Castro Meira, Segunda Turma, DJe 18.12.08.4.

Recurso especial provido.

(STJ, REsp 1.123.343/RS - 2009/0027242-2, Segunda Turma, Rel. Min. Castro Meira, julgado em 08/06/2010, DJE de 15/10/2010).

Da análise das decisões acima transcritas, nota-se que, embora os casos sejam correlatos, os desfechos formulados pelos órgãos julgadores foram distintos. No primeiro caso, a Primeira Turma confirmou acórdão que autorizou, ainda que indiretamente, o funcionamento da rádio comunitária, em face da omissão e mora da ANATEL. De outro modo, no segundo caso, a Segunda Turma negou a possibilidade de autorização precária do serviço de radiodifusão comunitária até a prolação de decisão definitiva pela agência. De acordo com o último acórdão, a atuação do Judiciário encontraria limites na fixação de prazo para que a mora fosse sanada, caso houvesse provocação nesse sentido.

Vale lembrar que, como exposto no segundo capítulo, quando se trata de regulação, o tratamento distinto aos agentes regulados sem elemento de discrímen que o justifique pode ocasionar instabilidades no sistema regulado que irão repercutir sobre os demais interessados na atividade regulatória (entre os quais se incluem os consumidores finais). Diferentemente do que se observa em uma demanda judicial comum, na qual, em regra, os interessados no deslinde da questão ocupam os pólos da relação processual, os efeitos da prestação judicial resultante do controle de atos regulatórios incidirão sobre a pluralidade de interesses públicos e privados tutelados pela agência. Ao tratar da insuficiência da atuação do Judiciário para tratar dos conflitos regulatórios, GOMES pontua (2006, p. 47):

\section{(...) é ilusório supor que o Judiciário, tal como concebido há mais de duzentos anos, e com o arcaísmo que marca particularmente a sua práxis entre nós, esteja à altura do desafio de dar solução rápida e eficaz aos conflitos de natureza cada vez mais intricada gerados pela modernidade ${ }^{41}$.}

Além disso, ainda que o Judiciário estivesse tecnicamente preparado para atuar de forma substitutiva às agências reguladoras - o que seria questionável,

\footnotetext{
${ }^{41}$ A crítica é particularmente interessante, uma vez que o autor é Ministro do Supremo Tribunal Federal.
} 
porque demandaria a duplicidade da estrutura de tais entidades - subsistiria a controvérsia quanto à legitimidade dessa atuação.

Sob essa perspectiva, decisões do Judiciário que substituam atos regulatórios podem conferir tratamentos distintos para situações correlatas de modo a colocar em risco o equilíbrio do setor regulado. Entende-se, contudo, que tais desdobramentos podem ser evitados (ou, ao menos, atenuados) quando o órgão judicial, ao anular decisões eivadas de vícios ou ao constatar omissões indevidas, se limita a fixar prazo para que a agência decida, observando os pontos indicados na decisão judicial.

Tal entendimento não mitiga a relevância do papel do Judiciário no controle dos atos regulatórios. Como defendido anteriormente, também o mérito da decisão combatida e, assim, o conteúdo da regulação, deve ser apreciado pelos órgãos judiciários. Nas palavras de MATTOS (2006, p. 363):

O Judiciário poderia - julgando o mérito de decisões administrativas ou do conteúdo da regulação estabelecido por meio de ato administrativo - realizar análise substantiva de adequação de justificativas sobre a motivação do ato administrativo em relação aos efeitos produzidos sobre os atores afetados, considerando os limites constitucionais e legais existentes, mas, também, os argumentos de mérito e justificativas apresentados pelos atores para fundamentar os efeitos almejados. Não caberia, porém, ao Judiciário, substituir o conteúdo da regulação por meio de sua decisão.

Não se ignora, contudo, que mesmo a decisão judicial quanto à invalidação de ato regulatório envolve análise sujeita à subjetividade do órgão julgador. Como destacado por VERISSIMO (2006, p. 407-408), a tarefa de delimitar critérios objetivos, puramente teóricos e apriorísticos, nos quais pudessem ser definidos os limites do controle judicial de atos administrativos em quaisquer situações, revela-se, hoje, infactível.

Entretanto, o entendimento de MATTOS acima citado sobre o alcance do controle judicial tem o mérito de não propor um controle de adequação do conteúdo da regulação a princípios ou objetivos constitucionais genéricos mediante interpretação na qual o Judiciário desvendaria qual o interesse público visado pela Constituição ou pelas leis setoriais. Ao contrário, o autor sugere uma modalidade de controle que permita uma avaliação das condições de deliberação sobre o conteúdo da regulação. Tal avaliação compreenderia a análise da conformação dos procedimentos administrativos existentes à deliberação - em audiências públicas e 
consultas públicas, por exemplo - e dos efeitos do conteúdo da regulação adotado sobre os atores afetados (MATTOS, 2006, p. 363). 


\section{APRIMORAMENTO DO CONTROLE JUDICIAL DE ATOS REGULATÓRIOS}

Para que o controle de conteúdo dos atos regulatórios seja viável, é necessário que o Poder Judiciário seja aparelhado de modo a tornar possível ao magistrado compreender a matéria tratada no ato impugnado, o contexto em que foi praticado, bem como as possíveis repercussões de sua suspensão ou anulação. A preparação do Judiciário para responder, de forma satisfatória, à demanda relativa à atividade regulatória não significa a duplicação da estrutura das agências reguladoras, o que seria não só infactível, mas também desnecessário. Isso porque, como sustentado no capítulo anterior, não cabe aos órgãos judiciários decidir de forma substitutiva aos agentes reguladores.

Entretanto, tampouco é defensável que o magistrado decida sobre questões de cunho regulatório ignorando regras elementares aos setores regulados, ou ainda, sem deter uma visão conjuntural da atividade regulatória. Como decorrências da compreensão insuficiente de questões regulatórias pelos órgãos judiciários, observam-se duas situações. Ora a atuação judicial limita-se ao exame de aspectos processuais em prejuízo de uma análise substancial do ato impugnado, ora seu conteúdo é examinado de forma desastrosa.

Apesar das dificuldades de apreciação do conteúdo de atos regulatórios, notadamente quando estão em questão assuntos de elevado grau de detalhamento técnico, a realização dessa análise pelo Judiciário é relevante para coibir arbitrariedades na atuação de agentes reguladores. Em outras palavras, embora o controle de conteúdo dos atos regulatórios envolva a apreciação de argumentos a princípio inerentes a outras áreas de conhecimento que não o Direito, o esvaziamento desse controle parece não ser a melhor solução. Como salientado no capítulo anterior, o mero exame de legalidade de tais atos pode comprometer a eficácia do controle judicial.

A respeito da permeabilidade de conhecimentos supostamente alheios ao Direito, ARAGÃO (2009, p. 92-93) salienta:

Não é dado ao jurista permanecer em uma clausura autista, ignorando as reações do subsistema econômico frente às normas jurídicas nem, muito menos, renunciar ao potencial regulatório, por vezes coercitivo, do Direito. (...) Sob esta perspectiva, o Direito deve buscar analisar o setor econômico a ser regulado, as circunstâncias em que se encontra e as possibilidades de regulação exógena, para, de forma inteligente, lograr maior efetividade para as suas normas. 
Por sua vez, DAROCA (1997, p. 119-127) sustenta que à medida que em uma regulação jurídica se utilizam conceitos que remetem a critérios técnicos, estes últimos passam a integrar-se ao ordenamento jurídico e, portanto, convertem-se, também, em parâmetros de legalidade.

Não obstante, de acordo com pesquisa realizada pela USP (2011, p. 21 22) sobre a atuação judicial no controle de atos exarados por agências reguladoras, em termos de qualidade das decisões, há, de certa forma, uma mistificação da complexidade da matéria regulatória. Como destacado por SUNDFELD e CÂMARA (2006, p. 636), de modo geral, os profissionais do Direito, tradicionalmente generalistas, dedicados ao domínio e aplicação das 'grandes leis' (primeiro os Códigos, depois a Constituição), ainda vêem a regulação como território estrangeiro, como o domínio dos técnicos. Ainda lhes é custoso penetrar nas especificidades, mesmo legais, dos setores regulados.

Ao mesmo tempo, os magistrados que ousam analisar o conteúdo do ato regulatório impugnado por vezes ignoram aspectos técnicos relevantes, ou ainda, os efeitos sistêmicos que a invalidação desse ato pode desencadear.

Nesse contexto, faz-se relevante o estudo de formas de aperfeiçoamento do controle de questões regulatórias pelo Poder Judiciário.

\section{1. Participação de agências reguladoras em processos judiciais}

O acentuado grau de especialidade de questões regulatórias submetidas à apreciação judicial torna pertinente o debate quanto à participação de agências reguladoras em processos nos quais não constem originariamente como parte.

CYRINO (2007), reconhecendo a necessidade de se considerar não só os argumentos jurídicos no controle judicial, como também elementos outros de teor empírico/pragmático, formula a seguinte questão acerca do controle de atos de órgãos reguladores:

Não seria a intervenção das entidades reguladoras em processos judiciais (sejam eles abstratos, sejam eles concretos), imprescindível, em casos de maior complexidade técnica, ou mesmo em hipóteses de difícil verificação, pelo Poder Judiciário, dos efeitos sistêmicos de sua decisão?

Entende-se que sim. Como destacado pelo autor, devem ser garantidos meios para a efetiva participação de entidades reguladoras, porque capazes de 
fornecer ao juiz estatísticas, análises empíricas e estudos técnicos em geral, de modo a subsidiar a tomada de decisão.

Muito embora o Judiciário reconheça as competências regulatórias das agências, observa-se que ainda há muito que se construir, na doutrina e na jurisprudência, quanto ao papel de tais entidades no processo judicial. Como destacado no segundo capítulo, as atribuições das agências reguladoras estão relacionadas à garantia de estabilidade dos setores regulados. Nessa linha, ainda que a prestação jurisdicional não repercuta diretamente na esfera jurídica do órgão regulador, de modo que ele não suporte os efeitos da decisão, subsiste seu interesse jurídico em assegurar o equilíbrio regulatório quando tais efeitos possam colocá-lo em risco.

Por esse prisma, mesmo quando se trate de discussão judicial travada entre agentes econômicos regulados, ou entre concessionária e consumidor, pode estar em questão a validade de decisão ou norma editada por agência reguladora. Desde logo, é importante salientar que não se pretende defender que tais entidades participem de qualquer processo que trate, ainda que indiretamente, de atos regulatórios. Tal medida não poderia sequer ser adotada, sob uma perspectiva pragmática.

De outro modo, o que se buscará problematizar é a avaliação do órgão julgador a respeito da necessidade e pertinência da intervenção das agências reguladoras no caso concreto. Como se verá, tal análise vem sendo feita de forma superficial, sem que se ponderem os possíveis impactos da resolução da lide à estabilidade dos setor regulado. Feitas tais considerações, cumpre tratar, portanto, de possíveis formas de intervenção processual de órgãos reguladores em demandas que não integrem inicialmente como partes.

\subsubsection{Amicus curiae regulatório}

$\mathrm{Na}$ ausência de uma expressão própria para corresponder ao significado de amicus curiae, parte da doutrina tem optado por adotar a terminologia amigo do juízo ou colaborador da Corte. Segundo OLIVEIRA (2008, p. 94), o amicus curiae é um auxiliar eventual que colabora em questões de alta relevância social ou política, ajudando o magistrado na tarefa de interpretar o direito para a aplicação no caso concreto. 
Entretanto, com base na natureza dessa modalidade de intervenção e na imparcialidade que se espera do órgão judicial, parece mais acertado o entendimento de que o amicus curiae seja um terceiro interessado na lide. Por iniciativa própria ou por determinação judicial, o amicus curiae intervém em processo pendente com o escopo de enriquecer o debate judicial sobre as mais diversas questões jurídicas, portando, para o ambiente judiciário, valores dispersos na sociedade civil e no próprio Estado, que, de uma forma mais ou menos intensa, serão afetados pelo que vier a ser decidido, legitimando e pluralizando, com a sua iniciativa, as decisões tomadas pelo Poder Judiciário (BUENO, 2010) ${ }^{42}$.

Embora seja dada mais ênfase ao instituto no âmbito do controle de constitucionalidade, a Lei n. 9.469, de 10 de julho de 1997, prevê, no parágrafo único de seu artigo quinto, uma importante forma de intervenção aplicável às agências reguladoras. É o teor do dispositivo:

Art. 5ำ A União poderá intervir nas causas em que figurarem, como autoras ou rés, autarquias, fundações públicas, sociedades de economia mista e empresas públicas federais.

Parágrafo único. As pessoas jurídicas de direito público poderão, nas causas cuja decisão possa ter reflexos, ainda que indiretos, de natureza econômica, intervir, independentemente da demonstração de interesse jurídico, para esclarecer questões de fato e de direito, podendo juntar documentos e memoriais reputados úteis ao exame da matéria e, se for o caso, recorrer, hipótese em que, para fins de deslocamento de competência, serão consideradas partes.

A previsão gerou perplexidade na doutrina processualista em face da possibilidade de intervenção processual de entidades de direito público independentemente da demonstração de interesse jurídico, porque suficiente a constatação de que o provimento judicial possa ter reflexos, ainda que indiretos, de natureza econômica.

Com efeito, o dispositivo denota hipótese de atuação dos entes reguladores como amici curiae regulatórios, aptos que são a auxiliar o Poder Judiciário na tomada de decisão, através do esclarecimento de questões técnicas e

\footnotetext{
42 De acordo com Bueno (2010) é inócuo, porque vazio de significado para a experiência jurídica brasileira, traduzir a expressão amicus curiae para o vernáculo. Ela, mesmo quando traduzida, não tem referencial na nossa história jurídica e, por isso, fica carente de verdadeira identificação. É insuficiente a "tradução vernacular" daquela expressão; é mister encontrar o seu referencial e seu contexto de análise no direito brasileiro. Prossegue o autor sustentando que nosso direito não conhece, pelo menos como este nome, um "amigo" ou um "colaborador" da "Corte", mesmo que se entenda por "Corte" os Tribunais ou, de forma ainda mais ampla, o Poder Judiciário. De resto, a atuação de qualquer sujeito processual que seja "amigo" do juiz pode comprometer a imparcialidade daquele que presta a jurisdição (art. 135, I, do Código de Processo Civil).
} 
sistêmicas, próprias da regulação econômica (CYRINO, 2007). Intervindo como amicus curiae, a agência reguladora pode esclarecer questões de fato e de direito, bem como juntar documentos e memoriais considerados úteis ao exame da matéria, de modo a colocar o órgão judiciário a par de questões que entenda relevantes ao deslinde do feito.

BUENO (2010) relaciona tal modalidade de intervenção à função de fiscal da lei (custos legis), desempenhada pelo Ministério Público e, em alguma medida, a de perito ou, ainda, a de um mecanismo de prova, no sentido de ser uma das variadas formas de levar ao magistrado, assegurada, por definição, sua imparcialidade, elementos que, direta ou indiretamente, sejam relevantes à resolução da lide ${ }^{43}$. Nessa linha, sustenta o autor:

É como se se dissesse que o amicus curiae faz as vezes de um "fiscal da lei" - e não do fiscal da lei que o direito brasileiro conhece, que é o Ministério Público - em uma sociedade incrivelmente complexa em todos os sentidos; como se ele fosse o portador dos diversos interesses existentes na sociedade civil e no próprio Estado e que, de alguma forma, tendem a ser atingidos, mesmo que em graus variáveis, pelas decisões jurisdicionais. Ele, o amicus curiae, tem que ser entendido como um adequado representante destes interesses que existem na sociedade e no Estado ("fora do processo", portanto) mas que serão afetados, em alguma medida, pela decisão a ser tomada "dentro do processo". O amicus curiae, neste sentido, atua em juízo para a tutela destes interesses, e é por isso mesmo que sua admissão em juízo depende sempre e em qualquer caso da comprovação de que ele se apresenta no plano material como um "adequado representante destes interesses".

Nessa perspectiva é que o instituto guarda relação com o papel desempenhado pelas agências reguladoras. Segundo ARAGÃO (2009, p. 291), as agências reguladoras expressam, como poucas instituições, as diversas mudanças que vêm caracterizando o Direito Público Econômico contemporâneo. Entre elas está a pluralidade de interesses públicos e privados que tais entidades têm sob sua tutela.

Corrobora esse entendimento o excerto a seguir, extraído do voto do relator na Medida Cautelar n. 9.275/AM, ao tratar das formas de intervenção

\footnotetext{
${ }^{43}$ Nesse sentido, uma verdadeira prova atípica traduzida na atuação de um terceiro interveniente, uma intervenção de terceiro cuja finalidade última é a de ampliar, aprimorando-o, o objeto de conhecimento do juiz com informações relativas a interesses metaindividuais (os "interesses institucionais" referidos de início) que serão afetados, em alguma medida, pela decisão a ser proferida: uma intervenção de terceiros com finalidade instrutória, portanto. Trata-se, por isso mesmo, de uma intervenção por inserção (BUENO, 2010).
} 
processual das agências reguladoras em litígio entre empresas do setor regulado no qual se discutam, incidentalmente, suas orientações:

Deveras, é possível à agência, coadjuvando uma das partes ou intervindo como singular custos legis à luz de sua finalidade institucional, fornecer nos autos informações úteis ao desate da lide.

De fato, como se constata do exame da legislação relativa às agências reguladoras, elas devem buscar a realização de interesses tão múltiplos e díspares como a universalização dos serviços sob sua regulação, a proteção dos consumidores, o desenvolvimento tecnológico nacional, a atração de investimentos estrangeiros, a ampliação da concorrência, a garantia do equilíbrio econômicofinanceiro, entre outros (ARAGÃO, 2009, p. 291).

No mesmo sentido, MARQUES NETO (2002, p. 207) aponta como pressuposto da existência das agências reguladoras sua capacidade de interlocução com os diversos atores enredados na atividade regulatória. Desse modo, é salutar que as agências reguladoras possam contribuir com o Judiciário, fornecendo uma visão sistêmica da questão discutida, sempre que, mesmo indiretamente, o equilíbrio dos interesses envolvidos na regulação possa estar ameaçado.

Embora timidamente, o Judiciário tem reconhecido a intervenção dos órgãos reguladores como amicus curiae em processos que tratem de questões regulatórias e possam refletir economicamente na sociedade ${ }^{44}$. Em alguns casos, tal modalidade interventiva vem ao encontro do desprestígio, junto ao Judiciário, das demais formas de participação processual.

Isso porque, como se demonstrará posteriormente, tem ganhado força no STJ o entendimento de que somente há interesse jurídico de agências reguladoras em demandas que repercutam diretamente em sua esfera jurídica. Nessa linha, uma vez que a intervenção como amicus curiae não requer demonstração de interesse jurídico, mas institucional ${ }^{45}$, por vezes o instituto é utilizado como forma de possibilitar a manifestação dos órgãos reguladores nos autos.

\footnotetext{
${ }^{44}$ Entre os precedentes em que se admitiu a intervenção de agência reguladora como amicus curiae confiramse: Recurso Especial n. 976.836/RS (2007/0187370-6), Primeira Seção, Rel. Min. Luiz Fux, julgado em 25.08.2010, Dje de 5.10.2010 e Recurso Especial n. 1.185.070/RS (2010/0043631-6), Primeira Seção, Rel. Min. Teoria Albino Zavascki, julgado em 22.9.2010, DJe de 27.9.2010.

${ }^{45}$ Embora se entenda que mesmo o interesse institucional das agências reguladoras seja também um interesse jurídico, a distinção é relevante em face da interpretação restritiva da noção de interesse jurídico adotada pelo STJ. Segundo BUENO (2010), um interesse institucional, que autoriza o ingresso de terceiro como amicus curiae em relação processual, deve ser entendido como aquele interesse que ultrapassa a esfera jurídica de um
} 
O acórdão prolatado no Recurso Especial n. 1.009.520/SP ilustra a situação narrada. No caso, a recorrente, Companhia Paulista de Força e Luz (CPFL), concessionária de serviço público de distribuição de energia elétrica, se insurgiu contra acórdão que manteve decisão que sustou, em tutela antecipada, os efeitos do contrato de fornecimento de energia elétrica firmado com a recorrida, Indústria e Comércio de Embalagens e Papéis Artivinco Ltda. e determinou a disponibilização de $\operatorname{contratos}^{46}$ necessários à aquisição de energia elétrica no mercado livre por esta empresa.

Nas razões do recurso, a CPFL alegou o interesse da ANEEL no feito com base no artigo $3^{\circ}$, IV, $\mathrm{V}$ e VI, ${ }^{47}$ da Lei 9.427 , de 26 de dezembro de 1996, que define as competências da agência para gerir contratos de concessão, dirimir divergências entre as concessionárias e consumidores, entre outras.

Segundo a recorrente, o vínculo jurídico existente entre ela e a ANEEL e a reciprocidade das conseqüências econômicas e jurídicas estabelecidas em função de possível deferimento da pretensão da recorrida, justificaria a caracterização do litisconsórcio necessário ou, ao menos, legitimaria a incidência do instituto da denunciação da lide. O último pedido decorreria da alegada responsabilidade objetiva da autarquia ao impor condutas à recorrida submetidas a questionamento judicial, de modo que seria forçosa a integração da ANEEL no pólo passivo da demanda.

Não obstante, com amparo na ausência de relação jurídica direta entre a autora e a ANEEL, decidiu o STJ que o caso não incide em hipótese de

indivíduo e que, por isso mesmo, é um interesse meta-individual, típico de uma sociedade pluralista e democrática, que é titularizado por grupos ou por segmentos sociais mais ou menos bem definidos.

${ }^{46}$ Contrato de Conexão ao Sistema de Distribuição - CCD e Contrato de Uso de Sistema de Distribuição - CUSD

47 Art. $3^{\circ}$ Além das atribuições previstas nos incisos II, III, V, VI, VII, X, XI e XII do art. 29 e no art. 30 da Lei $n^{\circ}$ 8.987, de 13 de fevereiro de 1995, de outras incumbências expressamente previstas em lei e observado o disposto no $\S 1^{\circ}$, compete à ANEEL: (Redação dada pela Lei no 10.848, de 2004) (Vide Decreto $n$ o 6.802, de 2009).

IV - gerir os contratos de concessão ou de permissão de serviços públicos de energia elétrica, de concessão de uso de bem público, bem como fiscalizar, diretamente ou mediante convênios com órgãos estaduais, as concessões, as permissões e a prestação dos serviços de energia elétrica; (Redação dada pela Lei no 10.848, de 2004)

V - dirimir, no âmbito administrativo, as divergências entre concessionárias, permissionárias, autorizadas, produtores independentes e autoprodutores, bem como entre esses agentes e seus consumidores;

VI - fixar os critérios para cálculo do preço de transporte de que trata o $\S 6^{\circ}$ do art. 15 da Lei $n^{\circ} 9.074$, de 7 de julho de 1995, e arbitrar seus valores nos casos de negociação frustrada entre os agentes envolvidos; 
litisconsórcio necessário ${ }^{48}$. No atinente ao pedido de denunciação da lide, tampouco logrou êxito a recorrente. Segundo o relator, a parte que enceta a denunciação da lide, o denunciante, ou tem um direito que deve ser garantido pelo denunciantetransmitente, ou é titular de eventual ação regressiva em face do terceiro, porque demanda em virtude de ato deste, o que não se aplicaria ao caso analisado.

Embora tenham sido indeferidos os pedidos de que a ANEEL integrasse a relação processual como parte, o relator do processo determinou a intimação da agência para se manifestar como amicus curiae no feito.

A partir dos esclarecimentos prestados pela ANEEL, afastou-se o perigo da demora ${ }^{49}$, bem como se concluiu que a fumaça do bom direito dependeria do reexame das cláusulas contratuais, análise estranha ao recurso especial ${ }^{50}$. Desse modo, a Primeira Turma do STJ decidiu, à unanimidade, pelo não provimento do recurso especial.

O precedente ilustra a relevância da intervenção do órgão regulador para trazer ao processo aspectos desconhecidos pelo juiz, mas necessários à adequada prestação jurisdicional. Uma vez que (i) o controle judicial é imprescindível a um Estado que se pretenda democrático e de Direito e que (ii) o Poder Judiciário não é capaz de levar em consideração todos os inevitáveis elementos não jurídicos, altamente relevantes para a sua tomada de decisão, bem como the carece conhecimento para averiguar as conseqüências sistêmicas de sua decisão, depreende-se que a participação da agência é fundamental para a compreensão de questões regulatórias relativas à lide, de sorte que o juiz pode requerer, de ofício, sua manifestação (CYRINO, 2007).

\footnotetext{
${ }^{48} \mathrm{O}$ fundamento apresentado pelo STJ para justificar a inexistência de litisconsórcio necessário, qual seja a ausência de relação jurídica direta entre uma das partes e a ANEEL, será analisado em tópico destinado a tal modalidade de intervenção processual.

${ }^{49}$ Consta do relatório que a ANEEL informou o seguinte: no que toca à contratação de energia elétrica pela Concessionária junto aos agentes vendedores, existe previsão de mecanismos de ajuste decorrentes de migração de consumidores potencialmente livres, evitando-se onerar demais consumidores, bem assim preservar o equilíbrio econômico-financeiro da concessão e a justa remuneração do concessionário. Além disso, salientou que eventuais alterações da sinalização tarifária experimentadas ao longo do tempo (da rescisão ao término regular da vigência contratual), podem repercutir na receita auferida pela Concessionária, todavia sem imputar ônus aos demais consumidores daquela área de concessão, uma vez que não são necessariamente reconhecidos pela ANEEL.

${ }^{50}$ Súmula n. 5, do STJ (10.05.1990; DJ de 21.05.1990). Interpretação de Cláusula - Recurso Especial: A simples interpretação de cláusula contratual não enseja recurso especial.
} 
A despeito da importância da intervenção de órgãos reguladores como amicus curiae, não estão pacificados na doutrina e, tampouco, na jurisprudência, os exatos contornos do instituto. Explica-se. Embora o parágrafo único, do artigo 5ํㅡㄹ da Lei n. 9.469, de 1997, preveja, expressamente, a possibilidade de interposição de recursos pelas entidades intervenientes, e afirme que, nessa hipótese, para fins de deslocamento de competência, elas serão consideradas partes, na prática, nega-se efetividade ao dispositivo e, por vezes, questiona-se sua constitucionalidade ${ }^{51}$. A questão é delicada e merece análise detida, o que fugiria, no entanto, aos objetivos deste estudo.

Por ora, é suficiente ressaltar que as divergências não se restringem à alteração de competência, mas também se referem à possibilidade de interposição de recursos que, para alguns autores, limita-se à insurgência contra o indeferimento de sua participação no processo ${ }^{52}$.

Nessa linha, LOUREIRO (2009) sustenta que a intervenção como amicus curiae não assegura à agência reguladora participação efetiva no processo, seja em virtude de ser possível ao relator indeferir seu ingresso na relação processual, seja porque, uma vez admitida sua intervenção, há, ainda, o risco de ser-lhe negada a condição de parte, coibindo-Ihe a participação em atos essenciais do procedimento, tais como a possibilidade de recorrer das decisões.

Não por outra razão, a intervenção dos reguladores como amici curiae, conquanto seja admitida, ainda encerra severas limitações quanto à concretização dos direitos de parte que assistem ao órgão

\footnotetext{
${ }^{51}$ Em síntese, a divergência se instaura porque, em uma interpretação literal, o deslocamento da competência para a Justiça Federal dar-se-á somente em caso da interposição de recursos pela entidade federal interveniente, o que gera a possibilidade de que um Tribunal Regional Federal reaprecie sentença de juiz estadual, hipótese que contraria o art. 108, II, da Constituição (CYRINO, 2010). Para BUENO (apud CYRINO, 2010), o dispositivo legal deve ser interpretado conforme a Constituição, deslocando-se a competência para a Justiça Federal desde a primeira instância, por força do art. 109, I, CF. CUNHA (apud CYRINO, 2010), por seu turno, apesar de reconhecer os problemas de sua solução, sustenta que o recurso deve ser interposto ao Tribunal de Justiça do Estado, que, ao dar-lhe provimento, irá anular a decisão ou a sentença, determinando a remessa dos autos à Justiça Federal para que sejam repetidos os atos processuais.

${ }^{52}$ A esse respeito, BUENO (2010) pontua que uma vez admitida a intervenção do amicus curiae para participar do processo é importante reconhecer a ele a possibilidade de atuar amplamente para atingir as finalidades que justificam a sua intervenção. Nessa linha, sustenta que deve ser reconhecida a legitimidade do amicus curiae não só para apresentar recurso contra a decisão que indefere seu ingresso, mas também para buscar uma mais adequada tutela dos direitos que justificam seu ingresso perante as instâncias recursais. Para o autor, também a possibilidade de produção de provas, compatíveis, evidentemente, aos limites em que é admitida sua intervenção, é medida que não pode aprioristicamente ser descartada. Deve-se, registrar, contudo, que o Projeto de Lei n. 8.046/2010, que dispõe sobre o Novo Código Processo Civil, caminha em sentido inverso. 0 parágrafo único do artigo 322, que trata do amicus curiae, estabelece que a intervenção não importa alteração de competência, nem autoriza a interposição de recursos.
} 
regulador. Bem por isso, será desarrazoado negar aos entes de regulação a participação nos autos como litisconsorte, sendo certo que é impossível subtrair-lhe o interesse em discutir causas nas quais pende de eficácia os atos por eles praticados no exercício da competência regulatória.

Embora não haja consenso quanto aos limites de atuação do amicus curiae, deve-se observar que o indeferimento de sua participação no processo requer fundamentação expressa, porque também sujeito ao princípio do livre convencimento motivado do juiz ${ }^{53}$.

Ademais, faz-se coro ao entendimento de CYRINO (2007), para quem contrariaria a própria lógica de uma atuação eficiente do Estado - a qual pressupõe a coordenação entre os Poderes -, que se ignorasse a existência, no bojo da própria Administração, de órgão legal e tecnicamente habilitado a informar sobre um determinado assunto, em seus mais amplos e conjunturais aspectos.

\subsubsection{Litisconsórcio e assistência processual}

As divergências quanto ao instituto do amicus curiae apontam a importância de se analisar a possibilidade de intervenção de agências reguladoras como litisconsortes ou assistentes processuais em lides cujos desfechos possam impactar, ainda que indiretamente, a estabilidade regulatória. É o caso, por exemplo, de processos que discutam, de forma incidental, a validade de seus atos ou que tratem de questões relacionadas às suas competências institucionais. Para enriquecer a reflexão, optou-se por trazer à baila alguns precedentes conexos ao tema.

Veja-se, por exemplo, o Recurso Especial n. 476.342/MT, que teve origem em ação civil pública de responsabilidade por danos causados ao consumidor, promovida pelo Ministério Público contra a Brasil Telecom S.A., Telecomunicações de Mato Grosso S.A - Telemat, a Empresa Brasileira de Telecomunicações S.A. - Embratel e a Interlig Comunicações Ltda..

Por meio do acórdão recorrido, o Tribunal de Justiça do Estado de Mato Grosso (TJMT) confirmou decisão que deferiu liminar determinando que as concessionárias aperfeiçoassem e modernizassem o sistema de telecomunicações

\footnotetext{
${ }^{53}$ Entretanto, como se observa no Recurso Especial n. 1.091.670/SP, em que a ANEEL requereu sua intervenção como amicus curiae, nem sempre o Judiciário se preocupa em fundamentar o indeferimento do pedido (Recurso Especial n. 1.091.670/SP - 2008/0215429-6, Segunda Turma, Rel. Min. Castro Meira, julgado em 28.09.2010, DJe de 15.10.2010).
} 
de Paranatinga, sob pena de multa diária no valor de $R \$ 100.000,00$. Também decidiu não se tratar o caso de hipótese de litisconsórcio passivo necessário com a agência reguladora ANATEL, por não ser o órgão do governo federal responsável pela execução dos serviços determinados pela decisão combatida, mas mero fiscalizador dos serviços prestados.

No recurso especial formulado pela Embratel, a concessionária insistiu ser imperiosa a formação de litisconsórcio com a ANATEL. Sustentou, assim, caber à ANATEL a fiscalização e o controle da qualidade dos serviços prestados aos usuários pelas respectivas empresas concessionárias, inclusive concedendo (sic) o poder de reprimir as eventuais infrações dos direitos dos usuários.

Ao analisar o pleito da recorrente, a Primeira Turma do STJ, com fulcro nos artigos $8^{054}$ e $19^{55}$, da Lei n. 9.472, de 16 de julho de 1997, entendeu que embora a agência reguladora Anatel não seja responsável pela execução dos serviços de aperfeiçoamento e modernização do sistema de telecomunicações, tem ela o dever de fiscalizar o serviço concedido. Nessa linha, admitiu ser justificável a sua integração no pólo passivo da demanda, já que cabe a ela a fiscalização de tais serviços.

Por conseguinte, à luz do disposto no artigo 109, $1^{56}$, da Constituição Federal, o STJ declarou nulo o acórdão proferido pelo TJMT, bem como determinou a remessa dos autos à Justiça Federal, em face de sua competência absoluta para julgar o feito.

\footnotetext{
${ }^{54}$ Art. $8^{\circ}$ - Fica criada a Agência Nacional de Telecomunicações, entidade integrante da Administração Pública Federal indireta, submetida a regime autárquico especial e vinculada ao Ministério das Comunicações, com a função de órgão regulador das telecomunicações, com sede no Distrito Federal, podendo estabelecer unidades regionais[...].

${ }^{55}$ Art. 19. À Agência compete adotar as medidas necessárias para o atendimento do interesse público e para o desenvolvimento das telecomunicações brasileiras, atuando com independência, imparcialidade, legalidade, impessoalidade e publicidade, e especialmente: [...].

$X$ - expedir normas sobre prestação de serviços de telecomunicações no regime privado;

XI - expedir e extinguir autorização para prestação de serviço no regime privado, fiscalizando e aplicando sanções;

${ }^{56}$ Art. 109. Aos juízes federais compete processar e julgar:

I - as causas em que a União, entidade autárquica ou empresa pública federal forem interessadas na condição de autoras, rés, assistentes ou oponentes, exceto as de falência, as de acidentes de trabalho e as sujeitas à Justiça Eleitoral e à Justiça do Trabalho.
} 
De outro modo, no julgamento do Recurso Especial n. 858.797/RS ${ }^{57}$, a Primeira Turma do STJ adotou entendimento diverso. No caso, o Ministério Público Federal recorreu de acórdão do Tribunal Regional Federal da 4⿳亠丷a Região, proferido em ação civil pública visando à suspensão da cobrança do Encargo de Capacidade Emergencial dos consumidores de energia elétrica, bem como à devolução dos valores pagos. O acórdão recorrido, ao negar provimento à apelação do Ministério Público, manteve a sentença de improcedência e decidiu, ainda, que a ANEEL não detém legitimidade para figurar no pólo passivo do processo.

No tocante à legitimidade da ANEEL para atuar como litisconsorte, 0 relator do recurso especial anotou que a questão está diretamente vinculada à natureza da relação jurídica de direito material controvertida. A partir do argumento de que a demanda havia sido proposta por consumidores (substituídos, no processo, pelo Ministério Público) e dizia respeito à relação jurídica contratual por eles estabelecida com a prestadora de serviço, sustentou que a ANEEL e, tampouco, a União se legitimavam a figurar como litisconsortes passivas.

A linha argumentativa adotada no precedente, e que vem ganhando força no $S T J^{58}$, funda-se na premissa de que, por não constar como parte da relação contratual que ensejou a lide, a ANEEL não deteria legitimidade para ser parte do processo judicial. Citando voto proferido no Recurso Especial n. 979.292/PB, o relator chegou a afirmar que quem não tem vínculo com a relação de direito material afirmada na inicial não é parte legítima, já que não é e nem pode ser beneficiada ou prejudicada em seu patrimônio jurídico pelo resultado da demanda.

O acórdão ignora, assim, que o interesse jurídico de agências reguladoras não se resume à afetação de seu patrimônio. Entretanto, o compromisso de tais entidades com a estabilidade regulatória projeta-se em relações às quais não se vincula diretamente, mas que possam impactar o equilíbrio do setor regulado. Como pontuado por GUERRA (2005, p. 271-272):

Quando um juiz decide modificar um ato administrativo de caráter geral, seja ele vinculado ou discricionário, exarado com o fim de

\footnotetext{
57 REsp n. 858.797/RS (2006/0055299-3), Primeira Turma, Rel. Min. Teori Albino Zavascki, julgado em 15.9.2009, DJe 23/9/2009

${ }^{58}$ REsp n. 744515/GO (2005/0065731-7), Segunda Turma, Rel. Min. Herman Benjamin, julgado em 27.3.2007, DJe de 30.9.2008; REsp n. 904.534/RS (2006/0258283-4), Rel. Min. Humberto Martins, Segunda Turma, julgado em 14.2.2007, DJ de 1.3.2007, p. 263; REsp n. 809504/RS (2006/0005719-5), Rel. Min. Castro Meira, Segunda Turma, julgado em 27.6.2006, DJ de 7.8.2006, p. 208; REsp n. 716.365/RS (2005/0002392-1), Rel. Min. Francisco Falcão, julgado em 7.11.2006, DJ de 14.12.2006, p. 257.
} 
apreciar um determinado direito, individual ou coletivo, os efeitos desse ato, em regra, afetam os administrados envolvidos, ou seus impactos quase sempre são abrandados e diluídos na coletividade.

Por outro lado, se o julgador alterar um ato administrativo regulatório, que envolve, fundamentalmente, a eleição discricionária dos meios técnicos necessários para o alcance dos fins e interesses setoriais despido das pressões políticas comumente sofridas pelos representantes escolhidos pelo sufrágio -, esse magistrado, na maioria das vezes, poderá, por uma decisão voltada a apenas um dos aspectos em questão, danificar a harmonia e equilíbrio de um subsistema regulado.

O precedente narrado ilustra o argumento de GUERRA. No mérito, o Ministério Público questionou a legitimidade da cobrança do Encargo de Capacidade Emergencial, previsto na Lei n. 10.438, de 26 de abril de 2002 e disciplinado pela Resolução ANEEL n. 249, 6 de maio de 2002. Ao julgar o recurso especial, o STJ manteve a decisão que negou provimento ao pleito do Ministério Público, ressaltando que o encargo não tem natureza de taxa, mas, sim, de preço público pago pela fruição da energia elétrica, em conformidade ao entendimento do STF, que já afirmara sua constitucionalidade ${ }^{59}$.

Não obstante, caso o STJ houvesse decidido pela suspensão da cobrança do referido encargo, bem como determinado a devolução dos valores pagos pelos consumidores, decerto haveria impacto no equilíbrio regulatório. Isso porque a cobrança do Encargo de Capacidade Emergencial instrumentaliza o rateio, entre consumidores finais de energia elétrica ${ }^{60}$, dos custos, inclusive de natureza operacional, tributária e administrativa, incorridos pela Comercializadora Brasileira de Energia Emergencial (CBEE) na contratação de capacidade de geração ou de potência. Foge à razão dimensionar o impacto da suspensão nacional desse rateio, além da devolução dos valores pagos a esse título.

Nota-se, assim, a importância de que as agências reguladoras possam atuar na qualidade de partes em demandas que, relacionadas às suas competências institucionais, configurem uma ameaça à estabilidade do sistema regulado. Contudo, tal qual salientado anteriormente, prevalece no STJ uma visão restritiva do

\footnotetext{
59 O Plenário do Supremo Tribunal Federal, ao julgar os RE's 576.189/RS e 541.511/RS, afirmou a constitucionalidade do Encargo de Capacidade Emergencial (Lei 10.438/02, art. 1ㅇ, § 1ㅇ; Resolução ANEEL 249/02, arts. 2o e 3ㅇ), do Encargo de Aquisição de Energia Elétrica Emergencial (Lei 10.438/02, art. 1으, § 2ㅇ; Resolução ANEEL 249/02, arts. 4으 e 5ㅇ), bem assim do Encargo de Energia Livre Adquirida no Mercado Atacadista de Energia Elétrica - MAE (Lei 10.438/02, art. 2ㅇ; Resolução ANEEL 249/02, arts. 11 a 14)

60 Conforme dispõe o artigo 2ㅇ, da Resolução ANEEL n. 249, de 2002, esse rateio se realiza entre os consumidores finais que tenham sido atendidos pelo Sistema Elétrico Interligado Nacional.
} 
significado de interesse jurídico processual. Desse modo, tem-se rechaçado a existência de litisconsórcio necessário pela mera análise dos integrantes da relação de direito material que deu ensejo ao pleito. É o que se depreende do acórdão prolatado no Recurso Especial n. 431.606/SP, cuja ementa segue transcrita:

PROCESSO CIVIL E ADMINISTRATIVO - LITISCONSÓRCIO AÇÃO CIVIL PÚBLICA CONTRA AUMENTO DE TARIFA TELLEFÔNICA - INTERVENÇÃO DA ANATEL.

1. Na relação de direito material, a empresa prestadora de serviço relaciona-se com a agência reguladora e uma outra relação trava-se entre a prestadora de serviço e os consumidores.

2. No conflito gerado na relação entre as prestadoras do serviço e os consumidores, não há nenhum interesse da agência reguladora, senão um interesse prático que não a qualifica como litisconsorte necessária.

3. Inexistindo litisconsórcio necessário, não há deslocamento da ação para a Justiça Federal.

4. Recurso especial improvido.

Não se pretende defender que agências reguladoras sejam litisconsortes necessárias em qualquer demanda que envolva agentes reguladores ou destinatários da atividade regulada. Tal entendimento implicaria não só o abarrotamento da Justiça Federal, como também tornaria infactível a atuação de assessorias jurídicas e de áreas técnicas de órgãos reguladores.

O que se espera, contudo, é que, ao examinar a participação processual de tais entidades, no caso concreto, o Judiciário não se detenha a uma análise rasa, cingida à afetação imediata da esfera jurídica da agência reguladora. Deve o Judiciário, de outra sorte, considerar os possíveis desdobramentos de sua decisão no tocante à estabilidade do sistema regulado e, assim, a relevância de que o órgão regulador não só se manifeste nos autos, mas também atue como parte no processo.

Todavia, quando muito, os tribunais têm admitido a intervenção da agência como assistente de uma das partes ${ }^{61}$. É o caso do Recurso Especial n.

A maior acolhida no Judiciário da participação das agências reguladoras como assistentes sugere estar
relacionada ao fato de que, na assistência, o terceiro interveniente recebe o processo no estado em que se
encontra (CPC, art. 50). Distintamente, o ingresso de autarquia federal como litisconsorte necessária exige o
deslocamento de competência para a Justiça Federal (CF, art. 109, I). No Recurso Especial n. 431.606/SP, já
citado, a relatora chegou a afirmar em seu voto que a pretensão da ANATEL em tornar-se litisconsorte
necessária, só despertada no curso da ação é, sem dúvida, manobra processual para inutilizar a ação civil
pública que, com sucesso para os consumidores, encontra-se em fase de apelação. Em semelhante sentido,
confira-se o REsp n. 589612/RJ, em que se negou provimento ao pedido de ingresso da ANS como litisconsorte
porque, da simples análise dos autos, ficou nítido que referido interesse restringe-se ao propósito de deslocar a
competência da causa para a Justiça Federal. (REsp n. 589612/RJ, Quarta Turma, Rel. Min. João Otávio de
Noronha, Rel. para acórdão Min. Honildo Amaral de Mello, julgado em 15/09/2009, DJe de 01.03.2010). É 
431.606/SP, acima mencionado, em que a relatora, ao negar a condição de litisconsorte da ANATEL, afirmou que a agência poderia ter ingressado no feito como assistente ad adjuvandum, por ter um interesse prático no desfecho da demanda. Essa, contudo, não parece ser a solução mais adequada para a garantia da imparcialidade e do equilíbrio da regulação.

Não se ignora que a atuação do órgão regulador como assistente de uma das partes possa ser uma alternativa para a defesa da validade de seus atos. Contudo, tal modalidade interventiva somente deve ser adotada quando o interesse do regulador coincidir com o interesse de uma das partes, o que nem sempre se verifica.

De todo modo, quer como assistente, quer como litisconsorte, é salutar que a participação de agências reguladoras em processos que questionem, ainda que incidentalmente, a legalidade de seus atos, seja analisada com maior profundidade pelos órgãos judiciários. O advento do Estado Regulador exige que também o Poder Judiciário revise noções como a de interesse jurídico, sob pena de colocar em risco o equilíbrio regulatório, tão caro aos interesses que pretende tutelar.

\subsection{Instrumentos e propostas para um controle de conteúdo dos atos regulatórios}

A diversidade de setores sujeitos à regulação e a especificidade das questões tratadas pelas agências torna inevitável o questionamento acerca da viabilidade prática do exame substantivo de atos regulatórios pelos juízes. Nas palavras de CYRINO (2007):

(...) Estão os nossos juízes preparados para isso? Seriam eles verdadeiros "Hércules", para usar a expressão de Dworkin, capazes de averiguar todos os aspectos relevantes para o controle da atuação estatal, sendo certo que na atuação do Estado regulador há muitos aspectos de ordem técnico-científica? Como possibilitar o controle judicial sem que a assimetria de informações entre Judiciário, reguladores e regulados atrapalhe mais que ajude a atuação eficiente do Estado?

certo, contudo, que utilização do processo para fins escusos por alguns jamais pode justificar a análise superficial da existência de litisconsórcio necessário com agência reguladora nacional, que, caso configurado, implicará a remessa dos autos a Justiça Federal. 
Conforme exposto, a participação das agências reguladoras no processo é relevante para a elucidação de questões regulatórias e para que sejam trazidos aos autos aspectos e desdobramentos da lide ignorados pelo juiz. Entretanto, é certo que o controle de conteúdo de atos regulatórios demanda outras soluções que possam subsidiar a prestação jurisdicional, para além da manifestação de tais entidades.

Embora as agências reguladoras tenham sido instituídas para assumir um papel de imparcialidade, na prática, é possível a captura de agentes reguladores para atuar em defesa de interesses estranhos às finalidades institucionais da agência. Assim, o caráter técnico e especializado da atuação de entidades reguladoras não as exime do escrutínio judicial.

Como sustentado no capítulo anterior, não se pode ter a ingenuidade de achar que a tecnicidade é sempre acompanhada da imparcialidade, já que, salvo em casos limites, o saber técnico pode perfeitamente ser instrumentalizado em favor de diversos fins políticos (ARAGÃO, 2009, p. 324). Desse modo, também os argumentos técnicos apresentados por entidades reguladoras, ao atuar como parte ou como terceiro interveniente, não podem ser adotados como verdades universais.

Nesse contexto, para um controle de conteúdo de atos regulatórios, deve o Judiciário se reformular, ou ainda, se valer de mecanismos que possam subsidiá-lo em sua decisão, sem prejuízo da participação das agências reguladoras no processo, o que, como se viu, também assume especial importância.

\subsubsection{Assistência pericial}

Conquanto não se conceba a ciência e a técnica como conhecimentos neutros, nota-se que a possibilidade de o magistrado conhecer da opinião de um especialista, em tese não vinculado a nenhuma das partes, pode contribuir para sua compreensão do tema.

DI PIETRO (2006), ao colocar em questão a denominada discricionariedade técnica dos órgãos reguladores, anota que a legislação processual permite que o juiz se socorra do auxílio de peritos para a tomada de decisões que envolvam dados técnicos que possam ser esclarecidos por 
especialistas $^{62}$. Por seu turno, DAROCA (1997) aponta que os critérios extrajurídicos estranhos à formação do julgador para controlar a concreção e aplicação do conceito jurídico indeterminado podem aportar-se através da prova pericial. De fato, conforme dispõe o caput do artigo $145^{63}$ do Código de Processo Civil, pode o juiz recorrer ao auxílio de um perito, sempre que o julgamento de mérito da causa dependa de conhecimentos técnicos de que não disponha (CÂMARA, 2004, p. 424).

Nessa esteira, aplicam-se ao controle de atos regulatórios as críticas de OTERO (2003, p. 768) à postura do Judiciário em apreciar meramente os casos de erro manifesto a partir do critério do ostensivamente inadmissível ou manifestamente desacertado. Para o autor, tal postura jurisprudencial, esquecendo a possibilidade de se recorrer a peritos, corre o risco de envolver uma limitação indevida do direito de impugnação contenciosa das decisões administrativas que é reconhecido pela Constituição.

Do exposto não resulta que o controle dos atos emanados de agências reguladoras seja deixado nas mãos de peritos. Isso porque o juiz não está vinculado nem às apreciações prévias do regulador, nem às conclusões do perito ${ }^{64}$ (DAROCA, 1997, p. 136). Ademais, como sustentado no capítulo anterior, não cabe ao magistrado a substituição da decisão impugnada, pelo que o entendimento do perito consultado não prevalece, obrigatoriamente, no caso concreto. Mas, decerto, sua participação no processo converge para a melhor compreensão das questões regulatórias pelos órgãos jurisdicionais.

\subsubsection{Realização de audiências públicas}

A realização de audiências públicas está relacionada à possibilidade de se dar voz à sociedade para se manifestar a respeito de questões que possam repercutir sobre os diversos interesses que a compõem.

No que tange às agências reguladoras, a realização de audiências públicas é de fundamental importância, uma vez que tais entidades legitimam-se

\footnotetext{
${ }^{62}$ Conforme prevêem os artigos 420 a 439 do Código de Processo Civil.

${ }^{63}$ Art. 145. Quando a prova do fato depender de conhecimento técnico ou científico, o juiz será assistido por perito, segundo o disposto no art. 421. (...)

${ }^{64}$ CPC, art. 436. O juiz não está adstrito ao laudo pericial, podendo formar a sua convicção com outros elementos ou fatos provados nos autos.
} 
democraticamente não pela eleição dos seus membros, mas pela participação da sociedade na formação de decisões de sua competência (JUSTEN FILHO, 2006).

Nesse contexto, o controle judicial dos atos regulatórios deve incidir também nos procedimentos adotados pelas agências reguladoras, de modo a se verificar se essa abertura democrática foi observada. Procedimentos que combinem a participação da sociedade com a exigência de motivação fornecem elementos para o controle judicial da atividade regulatória à luz da teoria dos motivos determinantes e, quando observados, fortalecem a presunção de legitimidade que deve ser atribuída aos atos deles resultantes (BRUNA, 2003, p. 275-276) ${ }^{65}$.

Entretanto, a mera realização de audiência pública ou a participação formal de interessados no processo decisório não é bastante para assegurar a higidez do procedimento. Segundo BRUNA (2003, p. 275-276), a validade do ato regulatório somente deve ser reconhecida pelo Judiciário quando a participação dos interessados tenha assumido significado prático, o que ocorre quando tenham sido efetivamente apreciados os principais argumentos apresentados durante $o$ procedimento de consulta pública. Tal análise pode ser realizada por meio da apreciação dos fundamentos apresentados pela autoridade reguladora ao acatar ou rejeitar tais argumentos.

Nessa linha, o autor destaca a importância da fundamentação dos atos regulatórios (BRUNA, 2003, p. 271):

Com efeito, nenhum sentido haveria em a lei exigir a realização de uma consulta pública, se a autoridade não estivesse obrigada a efetivamente examinar as contribuições dos interessados, acatandoas ou não, sempre de forma fundamentada.

\footnotetext{
65 JUSTEN FILHO (2006) acrescenta ser relevante que a própria definição dos procedimentos faça-se por via democrática. Segundo o autor, não há sentido em remeter a fixação dos procedimentos decisórios das agências à sua exclusiva e discricionária escolha. Um dos instrumentos de limitação dos poderes decisórios das agências reside na sua submissão a procedimentos fixados legislativamente. Remeter à competência administrativa da própria agência a determinação das regras processuais a que se submeterá é uma solução inadequada, que amplia o risco de a agência consagrar soluções procedimentais insuficientes ou inadequadas, impedindo a satisfação da função essencial reservada ao processo administrativo. Nessa linha, convém trazer à baila recomendação formulada por BRUNA (2003, p. 278): A fim de atender às peculiaridades das diversas situações de fato que devem ser objeto da ação normativa da Administração, seria recomendável que fosse adotado um diploma legislativo, no Brasil, com o propósito de disciplinar, de forma sistemática e uniforme, os procedimentos normativos do Executivo. Na elaboração de uma lei como essa, poderia ser aproveitada a experiência norte-americana da implantação e operacionalização do Administrative Procedure Act, já com mais de cinqüenta anos de aplicação, feitas as necessárias adaptações das lições assim colhidas às peculiaridades do sistema jurídico brasileiro. O estabelecimento de uma disciplina geral, de outra parte, não impediria a instituição e a manutenção dos regimes específicos estabelecidos de forma setorial por leis especiais, sempre que isso fosse desejável, tendo em vista as circunstâncias específicas do setor regulado.
} 
Também JUSTEN FILHO (2006) sustenta ser fundamental que a atividade decisória da agência incorpore a participação popular, mesmo quando não assinta às sugestões e às propostas apresentadas. Para o autor, incorporar a participação popular significa reconhecer como relevante a intervenção externa, acolhendo-a ou justificando sua rejeição.

Não se admite o fenômeno que se poderia qualificar como participação externa "cosmética". A expressão indica a situação em que a agência predetermina sua decisão e desencadeia uma série de formalidades, inclusive com audiências públicas, destinadas apenas a dar uma aparência de democracia à decisão. Assim, ouvem-se os particulares e os segmentos interessados, mas se adota decisão desvinculada de todas as contribuições.

Nesse contexto, caso o órgão julgador verifique que a participação dos particulares em determinado processo administrativo configurou uma mera formalidade, destituída de utilidade prática, entende-se que o ato regulatório que dele derivar deverá ser invalidado. Isso porque é inafastável a vedação a decisões produzidas no âmbito puramente interno da agência ou a ela transmitidas por autoridades políticas externas, cuja formalização seja precedida de um arremedo de processo. Desse modo, se a participação de terceiros no procedimento for desprovida de qualquer efeito prático, estará violado o postulado do devido processo administrativo (JUSTEN FILHO, 2003).

No mesmo sentido, confira-se a posição de VERISSIMO (2006, p. 413414), ao tratar do controle judicial da atividade normativa de agências reguladoras:

(...) A análise do processo administrativo utilizado na produção da norma pode relevar-se extremamente útil para a avaliação do grau de deferência que poderá merecer uma dada regra regulatória. A subtração de mecanismos de legitimação como consultas e audiências públicas ao processo de produção de uma dada norma regulatória compromete muito da deferência de que ela, de outro modo, poderia desfrutar. $O$ mesmo se pode dizer quanto ao comportamento do órgão de regulação no curso dessas audiências e consultas, ou seja, quanto ao grau de atenção que é dado, pelo órgão, a cada comentário e sugestão específica. Vale lembrar que as respostas dadas pelo órgão administrativo a tais sugestões ficam incorporadas, no processo normativo, como razões determinantes da regra baixada, possibilitando, assim, novas frentes de controle.

Sob essa perspectiva, o controle judicial da motivação de atos regulatórios revela-se de singular importância. A partir da análise dos fundamentos apresentados pelas entidades reguladoras, o Poder Judiciário pode verificar se as colaborações advindas da sociedade foram levadas em consideração na tomada de decisão, seja na resolução de um caso concreto ou na elaboração de uma norma 
regulatória ${ }^{66}$. Nas palavras de MATTOS, (2002, p. 66), esse tipo de avaliação significa testar o potencial democrático das agências como instituições que, apesar de órgãos técnicos, não deixam de ser órgãos políticos.

Entretanto, na hipótese de um ato regulatório questionado judicialmente não ser precedido de processo administrativo que assegure a efetiva participação de interessados, nada obsta, a princípio, que o Poder Judiciário possibilite tal abertura democrática no processo judicial.

Foi essa a solução adotada pelo juiz federal da $2^{\text {a }}$ Vara Federal da Seção Judiciária de Sergipe, em ação civil pública ${ }^{67}$ promovida pelo Ministério Público Federal contra a ANVISA. No caso registrado por ARAUJO (2010), o Ministério Público requereu provimento judicial para determinar que fossem inseridos, em rótulos de produtos submetidos ao controle da ANVISA, avisos relacionados ao desencadeamento de reações alérgicas.

Embora o autor houvesse requerido o julgamento antecipado da lide, 0 juiz optou pela instrução do processo, sobretudo para a aquisição e verificação de dados técnicos científicos necessários para a ponderação crítica das teses apresentadas pelos demandantes.

Ao primeiro passo, foi promovida audiência pública na qual foram ouvidos médicos especialistas com larga experiência no trato direto ou indireto de reações alérgicas correlacionadas a acidentes de consumo. Em face de dados que denunciavam o elevado número de acidentes de consumo atrelados a manifestações alérgicas, a ANVISA reconheceu o insucesso de seu aparato normativo no que tange à prevenção de tais acidentes:

(...) há necessidade de se adequar as frases de advertências existentes, quanto à linguagem, para torná-las mais fácil compreensão para os pacientes, e ampliar a lista de substâncias e princípios ativos para as quais há a necessidade de frases de advertências, por populações especiais, nas bulas e/ou embalagens de medicamentos.

Consta da decisão que o impacto dos dados levantados foi tão sensível que a ANVISA aquiesceu quanto à instalação de um grupo de trabalho para

\footnotetext{
${ }^{66}$ Isso significa que a agência independente tem o dever de justificar suas decisões regulatórias, inclusive apresentando os fundamentos pelos quais reputou inadequado acolher as colaborações, manifestações e propostas formuladas pela sociedade (JUSTEN FILHO, 2006).

67 2a Vara Federal da Seção Judiciária de Sergipe, Processo n. 2008.85.00.001185-2, Juiz Federal Substituto Fernando Escrivani Stefaniu.
} 
intensificar o debate plural iniciado na audiência pública, deixando vislumbrar a possibilidade de uma saída consensual para a demanda.

O grupo de trabalho, formado tanto por profissionais da área médica, quanto pelos integrantes da relação processual, tinha como objetivo tentar produzir, por consenso, propostas de alterações nas regras de rotulagens, com o objetivo de prevenir acidentes associados a reações alérgicas. Conforme exposto na decisão, as propostas consolidadas pelo grupo de trabalho não visavam à substituição das resoluções de competência da ANVISA, mas simplesmente somar, em termos mais diretos, regras elementares de fácil compreensão.

Ao decidir, o juiz federal julgou procedente o pedido e determinou fosse realizada a revisão da norma, com observância de parâmetros mínimos, definidos a partir de informações colhidas em audiência pública, bem como de propostas elaboradas pelo grupo de trabalho. Desse modo, foi possível ao magistrado suprir sua carência de conhecimento técnico não só por meio de manifestações da agência reguladora, mas também mediante a participação direta dos interessados.

Como destacado por ARAUJO (2010), a postura adotada pelo juiz federal em questão é iniciativa isolada que não se encontra procedimentalizada no Código de Processo Civil. Não obstante, consta do Projeto de Lei do Senado n. 166, de 2010, que trata do Novo Código de Processo Civil, previsão expressa de que os regimentos internos dos tribunais disponham sobre a realização de audiências públicas $^{68}$. De todo modo, convém ressaltar que ao magistrado cabe analisar a necessidade e relevância da realização de audiência pública judicial no caso concreto.

\subsubsection{Criação de varas especializadas em matérias regulatórias}

A dificuldade que, de modo geral, os magistrados possuem ao apreciar atos regulatórios pode ser atenuada por meio da criação de varas técnicas especializadas em processar e julgar ações relacionadas à regulação.

\footnotetext{
${ }^{68}$ Projeto de Lei do Senado n. 166, de 2010, art. 882: Os tribunais, em princípio, velarão pela uniformização e pela estabilidade da jurisprudência, observando-se o seguinte:

$\S$ 2o Os regimentos internos preverão formas de revisão da jurisprudência em procedimento autônomo, franqueando-se inclusive a realização de audiências públicas e a participação de pessoas, órgãos ou entidades que possam contribuir para a elucidação da matéria.
} 
ARAGÃO (2009, p. 323), ao tratar do caráter preponderantemente técnico da atuação das agências reguladoras, observa a necessidade de maior especialização dos juristas em face das constantes evoluções tecnológicas e da crescente complexização e pluralização do sistema social. Segundo o autor, esses fatos têm feito com que a especialização em determinado área do Direito deva ser acompanhada de profundos estudos técnicos sobre a matéria regulada, sendo cada vez mais comuns e necessários os "juristas-biólogos", "juristas-sanitaristas", "juristas-economistas", entre outros.

A criação de varas especializadas em matéria regulatória foi apontada por RAMALHO (2009, p. 151) e também por MARQUES NETO (2005, p. 209), que incluiu a solução em sua proposta de Lei Quadro para as Agências Reguladoras Independentes (ARIs):

Art. 129: A apreciação judicial de todos os feitos que envolvam atos praticados pelas ARIs ou matérias sujeitas à sua competência caberá a varas especializadas em direito regulatório a serem criadas no âmbito da Justiça Federal, com observância do disposto no art. 96, I, "d", da Constituição Federal.

Não se tem notícia de que existam, atualmente, varas com tal especialidade em nenhuma seção judiciária brasileira (USP, 2011, p.9). Tampouco o Projeto de Lei n. 3.337, de 2004, concebido para se tornar a lei geral das agências reguladoras, menciona a criação de varas especializadas. Não obstante, nada há no ordenamento jurídico brasileiro que impeça sua criação ou mesmo a especialização de varas já existentes.

Em verdade, conforme julgados recentes do Supremo Tribunal Federal ${ }^{69}$, a especialização da competência em razão da matéria de varas já concebidas sequer é tema exclusivo de lei, podendo ser feita por atos normativos dos tribunais. É o que dispõe o artigo 96, I, $a^{70}$, da Constituição Federal e o artigo $12^{71}$, da Lei n. 5.010, de 30 de maio de 1966, que organiza a Justiça Federal de primeira instância.

\footnotetext{
${ }^{69}$ Nesse sentido, confiram-se os seguintes precedentes: STF, HC 96.104/MS, Primeira Turma, Rel. Min. Ricardo Lewandowski, julgado em 16.06.2010, DJ de 06.08.2010; STF, HC 94.146/MS, Segunda Turma, Rel. Min. Ellen Gracie, julgado em 21.10.2008, DJ de 06.11.2008; e STF, HC 91.253/ MS, Primeira Turma, Rel. Min. Ricardo Lewandowski, julgado em 16.10.2007, DJ de 13.11.2007.

${ }^{70}$ Art. 96. Compete privativamente:

I - aos tribunais:

a) eleger seus órgãos diretivos e elaborar seus regimentos internos, com observância das normas de processo e das garantias processuais das partes, dispondo sobre a competência e o funcionamento dos respectivos órgãos jurisdicionais e administrativos;
} 
Nos Tribunais Regionais Federais, a distribuição dos recursos entre as seções e as turmas que as compõem observa o que estabelecem os respectivos Regimentos Internos. Não há nos Regimentos Internos desses tribunais a previsão de uma seção ou turma especializada em causas que questionem decisões de agências reguladoras. O que mais se aproxima da matéria são as varas especializadas para julgar feitos de natureza administrativa ou feitos relativos à nulidade e anulabilidade de atos administrativos, especialização que se reputa vaga, dadas as particularidades dos atos regulatórios ${ }^{72}$.

Como vantagens da criação de tais varas ou turmas especializadas, citem-se (i) o ganho de experiência e melhor compreensão do modelo e do direito regulatório pelos magistrados que poderão, inclusive, participar de cursos de capacitação específicos; (ii) a possibilidade de aparelhá-las com suporte técnico de assessores e peritos especializados em áreas de conhecimento correlatas à atuação das agências reguladoras, tais quais economia, medicina e engenharia; e (iii) a possível redução da média de tempo de duração do processo, em razão da expertise adquirida pelos órgãos julgadores e da diminuição de conflitos de competência em tribunais (USP, 2011).

Por outro lado, a concentração de especialistas com a função de auxiliar os magistrados na revisão de atos regulatórios poderia suscitar um fenômeno análogo ao da captura de agentes reguladores. Essa desvantagem seria, contudo, atenuada tendo em vista a independência do magistrado quanto ao entendimento esposado por assessores ou peritos. De todo modo, mesmo não se podendo afirmar que as análises de tais especialistas sejam mais acertadas ou menos corruptíveis do que as realizadas pelas agências reguladoras, parece que a simples possibilidade de se aprofundar o debate em torno de questões regulatórias, por meio de um melhor aparelhamento do Judiciário, supera os argumentos em contrário.

\footnotetext{
${ }^{71}$ Art. 12. Nas Seções Judiciárias em que houver mais de uma Vara, poderá o Conselho da Justiça Federal fixarIhes sede em cidade diversa da Capital, especializar Varas e atribuir competência por natureza de feitos a determinados Juízes.

72 Os dados apresentados referem-se a consultas dos Regimentos Internos disponíveis nos sites dos TRFs em novembro de 2011.
} 


\section{CONCLUSÕES}

Por meio deste trabalho, procurou-se demonstrar que ainda há muito a se progredir no que concerne ao controle judicial de atos regulatórios. Nos moldes atuais, ou há um controle fraco de atos regulatórios discricionários (sem controle de mérito quando se trata de juízo de conveniência ou oportunidade), ou há um controle meramente formal de legalidade de normas de conjuntura editadas pelas agências reguladoras, ou ainda, não há, na prática, controle algum (MATTOS, 2006, p. 358).

Para além do reconhecimento da ambiguidade e ineficiência da revisão judicial de atos regulatórios, buscou-se, ao longo desta monografia, apontar os limites e contornos próprios a essa modalidade de controle.

Com esse escopo, no primeiro capítulo, procurou-se explicitar em que medida as entidades reguladoras independentes inovaram o modelo clássico de Administração Pública. Nesse contexto, ressaltou-se sua independência em face da Poder Central e a amplitude de suas funções, tipicamente relacionadas aos poderes Executivo, Legislativo e Judiciário.

Observou-se, ainda, que o fato de as agências reguladoras não possuírem dirigentes eleitos pelo povo e deterem elevado grau de autonomia em relação à Administração Pública central não implica, por si só, a existência de déficit democrático em sua atuação. Não obstante, admitiu-se que tais entidades possam carecer de legitimidade democrática sempre que os critérios de sua organização e funcionamento frustrem ou dificultem a realização dos princípios e valores fundamentais (JUSTEN FILHO, 2006).

Por esse prisma e, considerando o risco de captura dos agentes reguladores, reputou-se fundamental a existência de sistemas de limitação de competências, inerentes a um Estado Democrático de Direito. Nessa esteira, se abordou a necessidade de um controle judicial efetivo, cuja análise foi realizada nos capítulos seguintes.

No segundo capítulo, anotou-se que a independência das agências reguladoras não pode ser afirmada plenamente em relação ao Poder Judiciário. Ressaltou-se, ainda, que o estudo do controle judicial de atos regulatórios assume contornos próprios e especial relevância em razão da ampla discricionariedade 
conferida pela lei às agências reguladoras, ao caráter técnico-especializado do seu exercício e ao equilíbrio sensível entre os interesses difusos e os objetivos dos particulares envolvidos, sejam eles agentes econômicos ou consumidores.

A partir dos estudos realizados pela ABDIB em 2008 e 2011, constatou-se que a judicialização de questões regulatórias possui trajetória ascendente e que o ritmo de resolução judicial dos conflitos é quase quatro vezes menor que o de ajuizamento de novas ações.

Ademais, a pesquisa realizada pela USP apontou que o Judiciário, além de consumir tempo excessivo para apreciar em definitivo os atos submetidos a seu controle, profere decisões de baixa qualidade técnica em razão do despreparo para apreciar políticas regulatórias, questões técnicas econômicas ou setoriais e ponderar interesses individuais e coletivos em jogo. Concluiu-se, ainda, que, ao combinar a intervenção suspensiva de atos de agências com a confirmação da decisão após longo tempo de oscilações por parte de órgãos julgadores, o Poder Judiciário dá uma sinalização ruim às agências e ao mercado.

A imprevisibilidade das decisões do Judiciário pode reverter-se em insegurança jurídica, uma vez que a regulação de uma atividade econômica envolve continuamente a tomada de decisões de grande transcendência para os regulados. A insegurança quanto à execução dos termos contratados, por sua vez, pode comprometer o equilíbrio regulatório e, nesse contexto, impactar negativamente também o consumidor comum, gerando efeito inverso ao pretendido pelo órgão jurisdicional.

Como agravante, observou-se que a ausência de especialização técnica dos magistrados quanto a temas regulatórios específicos, bem como a falta de uma visão sistêmica do setor regulado, podem significar a prolação de decisões não somente imprevisíveis, mas também atécnicas.

Apesar das deficiências constatadas, ponderou-se que a simples possibilidade de sujeição de atos regulatórios à revisão judicial já provoca um efeito positivo na atuação das agências reguladoras e demanda a adequada motivação de suas decisões, mesmo quanto aos critérios técnicos utilizados.

Contudo, para ser eficaz, o controle judicial deve congregar qualidade e capacidade de oferecer respostas em tempo concorrencial, ou seja, em um prazo compatível com a celeridade das transformações de mercado. Além disso, ao decidir, os magistrados devem ponderar que os efeitos de sua decisão não só 
incidem sobre os integrantes dos polos da relação processual, como também interferem no equilíbrio regulatório a que as agências visam a resguardar. Só assim é possível falar em controle judicial sem prejuízo da estabilidade do sistema regulado, essencial à qualidade dos serviços prestados, ao aporte de investimentos pelos agentes privados e à composição de interesses afetados pela regulação.

O terceiro capítulo tratou dos limites do controle judicial de atos regulatórios. Concluiu-se que, embora o exame de legalidade seja uma importante forma de controle, o controle judicial não deve ser a ele reduzido. No que toca às atividades reguladas, há uma tendência de que a lei se limite a fixar parâmetros sobremodo abertos. Desse modo, cingir o controle judicial ao controle de legalidade e, assim, à observância de tais parâmetros, significa anular a efetividade do controle judicial.

Nessa linha, sustentou-se que não deve o Judiciário se furtar a realizar um controle de mérito sob o argumento de que a decisão foi concebida a partir do exercício de discricionariedade técnica própria às agências reguladoras. Como se viu, a própria noção de discricionariedade técnica é passível de questionamentos.

Conquanto se tenha reconhecido que órgãos reguladores, em função de sua especialidade, possam decidir com base em conhecimentos técnicos a respeito da matéria que Ihes é afeta, verificou-se que tais fundamentos também se sujeitam ao controle judicial.

Além disso, contestou-se a premissa adotada por parte da doutrina e da jurisprudência, segundo a qual a tecnicidade das decisões prolatadas por agências reguladoras afasta o controle judicial. Como apurado, mesmo quando as decisões devam pautar-se por critérios técnicos, sempre haverá margem para a subjetividade. Por meio dessa análise, pretendeu-se objetar a pretensão de se conferir neutralidade aos atos regulatórios. Com efeito, ocultar critérios políticos adotados em uma decisão sob o color da tecnicidade pode gerar conseqüências funestas ao sistema regulado.

A insuficiência do controle de legalidade e, por conseguinte, a relevância do controle de mérito de atos regulatórios, não significa, contudo, que caiba ao magistrado definir que medidas regulatórias são mais razoáveis ou adequadas ao caso concreto. Tal entendimento corresponderia, no limite, à substituição da discricionariedade do regulador pela do juiz, uma vez que também os parâmetros 
para se determinar o que seria uma decisão razoável, proporcional, ou mesmo uma decisão ótima são relativos e envolvem a adoção de critérios subjetivos.

Não obstante, da análise de precedentes do STJ, constatou-se que a jurisprudência tem oscilado quanto aos limites do controle exercido pelo Poder Judiciário e, por vezes, tem-se decidido de forma substitutiva às agências reguladoras. Essa postura é preocupante tendo em vista que, quando se trata de regulação, conferir tratamento distinto aos agentes econômicos ou aos destinatários da atividade regulada pode ocasionar instabilidades no setor. As conseqüências, por sua vez, podem repercutir não só entre as partes, mas também sobre a pluralidade de interesses públicos e privados tutelados pela agência. Nessa linha, decisões do Judiciário que substituam atos regulatórios podem colocar em risco o equilíbrio do setor regulado.

Por todo o exposto, sustentou-se que a amplitude do exame judicial não autoriza a substituição do agente regulador pelo juiz. Nessa perspectiva, caso o Judiciário anule uma decisão regulatória discricionária, o magistrado deverá devolver o assunto à agência reguladora para que decida novamente, levando em consideração os pontos indicados na decisão judicial. De modo análogo, constatada a omissão indevida do ente regulador, pode o Judiciário fixar prazo para que a agência se manifeste, mas não decidir em seu lugar.

Ressaltou-se, ainda, que um controle judicial efetivo não consiste na análise de adequação do conteúdo da regulação a princípios ou objetivos constitucionais genéricos mediante interpretação na qual o Judiciário desvendaria qual o interesse público pretendido pela Constituição ou pelas leis setoriais. Primeiro porque inexiste método objetivo de definição do que seja o interesse público (SHAPIRO, 1988, p. 5), razão pela qual não se pode inferir a existência de um único interesse público a ser observado. Segundo porque, considerando ser inadequado falar abstratamente em interesse público, exorbita as competências do Judiciário a definição de que interesse deva ser perseguido pelas agências reguladoras.

Nessa esteira, adotou-se o entendimento esposado por MATTOS (2006, p. 363), segundo o qual o controle judicial de mérito dos atos regulatórios deve avaliar as condições de deliberação sobre o conteúdo da regulação. Tal avaliação compreenderia a análise da conformação dos procedimentos administrativos existentes à deliberação - em audiências públicas e consultas públicas, por exemplo - e dos efeitos do conteúdo da regulação adotado sobre os atores afetados. 
Por fim, no quarto capítulo, apresentaram-se soluções para o aprimoramento desse controle. Pontuou-se que, para um controle de mérito efetivo, deve o Poder Judiciário se aperfeiçoar de modo que seja possível ao órgão julgador compreender, no caso concreto, o conteúdo e os efeitos do ato regulatório impugnado, na medida necessária ao deslinde da controvérsia.

Foram apontadas duas possíveis implicações da carência de conhecimento especializado e da falta de uma compreensão sistêmica da atividade regulatória pelos magistrados. A primeira se refere à realização de um controle adstrito a aspectos processuais, em detrimento de um controle substancial do ato questionado. A segunda conseqüência diz respeito à atuação de alguns órgãos julgadores que, embora realizem um controle de conteúdo, o fazem de forma desastrosa, por ignorar questões regulatórias importantes relativas à lide.

No sentido de suprir as lacunas apontadas, assinalou-se a importância de que as agências reguladoras possam intervir em processos nos quais não constem originariamente como parte, mas que possam interferir no equilíbrio regulatório, por estarem relacionados à validade de seus atos ou envolverem suas competências institucionais. Como salientado, a depender do caso, a participação de tais entidades no processo pode ser relevante à compreensão da controvérsia pelo juiz, porque capazes de fornecer informações a respeito de questões regulatórias que lhe são afetas e, assim, subsidiar a tomada de decisão.

A partir do estudo de acórdãos do STJ, observou-se que os tribunais ainda analisam a existência de interesse jurídico das agências reguladoras sob uma perspectiva atomizada do processo somada a uma visão clássica da Administração Pública. Assim, a despeito das competências institucionais das entidades reguladoras, o Judiciário tem infirmado seu interesse em intervir, alegando que os efeitos da decisão não irão repercutir diretamente em sua esfera jurídica, ou, ainda, que elas não compõem a relação de direito material que ensejou o pleito. Ignora-se, portanto, que o interesse jurídico de agências reguladoras não se resume à afetação de seu patrimônio.

Todavia, ainda que órgão regulador não suporte os efeitos da decisão, subsiste seu interesse em assegurar a estabilidade do setor regulado, sempre que tais efeitos possam ameaçá-la. Por essa razão, mesmo quando se trate de disputa judicial travada entre agentes econômicos regulados, ou entre concessionária e consumidor, pode estar presente o interesse da agência em atuar no processo. 
Assim, foram trabalhadas possíveis formas de intervenção processual de agências reguladoras e, neste particular, características de sua atuação como amicus curiae, assistente e litisconsorte.

Defendeu-se, em suma, que, ao examinar a participação processual de entidades reguladoras, no caso concreto, o Judiciário não se detenha a uma análise rasa, restrita à afetação imediata de sua esfera jurídica. Devem os magistrados, de outra sorte, considerar os possíveis desdobramentos de sua decisão no atinente à estabilidade do sistema regulado e, assim, ponderar a relevância da intervenção do órgão regulador.

Para além da participação processual das agências reguladoras, ressaltou-se a necessidade de que o Judiciário se valha de outras formas de aperfeiçoamento de sua atuação. Isso porque, embora as agências reguladoras tenham sido instituídas para assumir um papel de imparcialidade, na prática, é possível a captura de agentes reguladores para atuar em defesa de interesses alheios à missão institucional da agência. Além disso, como demonstrado, mesmo as decisões de ordem técnica de tais entidades são sindicáveis pelo Poder Judiciário. Nessa esteira, a participação processual das agências reguladoras apesar de relevante, não é suficiente para sanar as deficiências da apreciação judicial de atos regulatórios.

Desse modo, passou-se analisar outras formas de aprimoramento da prestação jurisdicional. $\mathrm{O}$ auxílio de peritos foi apontado como um instrumento subutilizado, apesar de importante para o esclarecimento de questões regulatórias que demandem conhecimento especializado. Como exposto, a assistência pericial ao juiz não significa relegar a tais profissionais o controle de atos emanados de agências reguladoras, tendo em vista que o juiz não está vinculado às conclusões do perito.

Também se anotou a importância do controle dos procedimentos adotados em audiências públicas, cuja realização é fundamental à legitimidade democrática dos órgãos reguladores. Ressaltou-se, contudo, que a mera realização de audiência pública ou a participação formal de interessados no processo decisório não são bastantes para assegurar a higidez do procedimento. Por essa razão, afirmou-se, à luz da teoria dos motivos determinantes, que as agências reguladoras devem analisar de forma motivada os argumentos trazidos pela sociedade, seja para acolhê-los, seja para rejeitá-los. 
Além disso, registrou-se a possibilidade de que o órgão julgador promova audiência pública judicial na hipótese de o ato questionado não ser precedido de processo administrativo que assegure a efetiva participação de interessados. É certo, contudo, que a necessidade e a relevância da realização de audiência pública devem ser avaliadas pelo juiz, no caso concreto.

Sugeriu-se, ainda, a criação de varas e turmas especializadas em processar e julgar ações relacionadas a atos praticados pelas agências reguladoras ou matérias sujeitas à sua competência. Como salientado, não existem óbices no ordenamento jurídico para a implementação dessa proposta. Ademais, apontou-se, como possíveis benefícios i) o ganho de experiência dos juízes titulares no trato de matérias regulatórias; ii) a possibilidade de aparelhá-las com assessoria especializada; iii) a conseqüente otimização do tempo de análise de questões regulatórias pelos órgãos julgadores.

Decerto, as críticas e sugestões aventadas não esgotam o debate acerca do controle judicial de atos regulatórios. Tampouco seria possível fazê-lo. A complexidade do tema requer $\mathrm{o}$ aprofundamento do estudo, bem como 0 comprometimento do Judiciário com a busca de soluções compatíveis com o paradigma do Estado Regulador. De todo modo, como primeiro passo, é fundamental que se reconheçam as falhas procedimentais e de conteúdo que vem sendo cometidas na realização desse controle. 


\section{REFERÊNCIAS BIBLIOGRÁFICAS}

AMARAL, Alexandra da Silva. Princípios Estruturantes das Agências Reguladoras e os Mecanismos de Controle. Rio de Janeiro: Lumen luris, 2008.

ANÁLISE de Infra-estrutura, A escalada de ações judiciais na infra-estrutura. Ano III, n. 13, out. 2008. Disponível em: <http://www.abdib.org.br/index/analise_infraestrutura.cfm>. Acesso em: 27 nov. 2011.

ARAGÃO, Alexandre Santos de. Agências Reguladoras e a Evolução do Direito Administrativo Econômico. Rio de Janeiro: Forense, 2009.

ARANHA, Márcio lorio; LOUREIRO, Luiz Gustavo Kaercher. Direito Regulatório. Apostila disponibilizada no Curso de Especialização em Direito Público realizado na UnB, em 2009.

ARAUJO, Luiz Eduardo Diniz. Controle da atividade normativa das agências reguladoras. 2010. 154f. Dissertação (Mestrado em Direito Público) - Faculdade de Direito, Universidade Federal de Recife, Recife.

BARROSO, Luís Roberto. Apontamentos sobre as agências reguladoras. In: MORAES, Alexandre de (Org.). Agências Reguladoras. São Paulo: Atlas, 2002, p. 109 a 143.

BRASIL. Código de Processo Civil. Lei n. 5869, de 11 de janeiro de 1973. Brasília. Diário Oficial da União de 17.1.1973. Disponível em: < http http://www.planalto.gov.br/ccivil_03/leis/L5869compilada.htm> Acesso em: 27 nov. 2011.

. Constituição (1988). Constituição da República Federativa do Brasil: promulgada em: 5 de outubro de 1998. Disponível em: <http://www.planalto.gov.br/ccivil_03/constituicao/constitui\%C3\%A7ao.htm> . Acesso em: 27 nov. 2011.

. Constituição (1967). Constituição da República Federativa do Brasil: promulgada em: 24 de janeiro de 1967. Artigo 153. Disponível em: < http://www.planalto.gov.br/ccivil_03/constituicao/constituica067.htm> . Acesso em: 27 nov. 2011.

. Lei n. 5.010, de 30 de maio de 1966. Organiza a Justiça Federal de primeira instância, e dá outras providências. Brasília. Diário Oficial da União de $1^{\circ}$ de junho de 1966. Retificado em 4 de julho de 1966. Disponível em: <http://www.planalto.gov.br/ccivil_03/leis/L5010.htm>. Acesso em: 20 nov. 2011.

. Lei n. 9.307, de 23 de setembro de 1996. Dispõe sobre a arbitragem. Brasília. Diário Oficial da União de 24 de setembro de 1996. Disponível em: <http://www.planalto.gov.br/ccivil_03/leis/L9307.htm>. Acesso em: 20 nov. 2011. 
Lei n. 9.469, de 10 de julho de 1997. Regulamenta o disposto no inciso VI $\overline{\text { do art. 4}}^{\circ}$ da Lei Complementar $n^{\circ}$ 73, de 10 de fevereiro de 1993; dispõe sobre a intervenção da União nas causas em que figurarem, como autores ou réus, entes da administração indireta; regula os pagamentos devidos pela Fazenda Pública em virtude de sentença judiciária; revoga a Lei no 8.197, de 27 de junho de 1991, e a Lei no 9.081, de 19 de julho de 1995, e dá outras providências. Brasília. Diário Oficial da União de 11 de julho de 1997. Disponível em: < http://www.planalto.gov.br/ccivil_03/leis/L9469.htm>. Acesso em: 20 nov. 2011.

. Lei n. 9.472, de 16 de julho de 1997. Dispõe sobre a organização dos serviços de telecomunicações, a criação e funcionamento de um órgão regulador e outros aspectos institucionais, nos termos da Emenda Constitucional no 8, de 1995. Brasília. Diário Oficial da União de 11 de julho de 1997. Disponível em: <http://www.planalto.gov.br/ccivil_03/leis/L9472.htm >. Acesso em: 20 nov. 2011.

. Lei n. 10.438, de 26 de abril de 2002. Dispõe sobre a expansão da oferta de energia elétrica emergencial, recomposição tarifária extraordinária, cria o Programa de Incentivo às Fontes Alternativas de Energia Elétrica (Proinfa), a Conta de Desenvolvimento Energético (CDE), dispõe sobre a universalização do serviço público de energia elétrica, dá nova redação às Leis $\mathrm{n}-9.427$, de 26 de dezembro de 1996, nำ 9.648, de 27 de maio de 1998, nํㅜ 3.890-A, de 25 de abril de 1961, nํ 5.655, de 20 de maio de 1971, no 5.899, de 5 de julho de 1973, no 9.991, de 24 de julho de 2000, e dá outras providências. Brasília. Diário Oficial da União de 29 de abril de 2002. Disponível em: <http://www.planalto.gov.br/ccivil_03/leis/2002/L10438.htm>. Acesso em: 20 nov. 2011.

Superior Tribunal de Justiça. Medida Cautelar n. 9.275/AM (2004/0168957-0), Primeira Turma, Relator Ministro Luiz Fux, julgado em 7.5.2005, Diário de Justiça da União de 23.5.2005, p. 148.

Superior Tribunal de Justiça. Recurso Especial n. 431.606/SP (2002/0049291-7), Segunda Turma, Relatora Ministra Eliana Calmon, julgado em 15.8.2002, Diário de Justiça da União de 30.9.2002, p. 249.

Superior Tribunal de Justiça. Recurso Especial n. 572.070/PR (2003/0128035-1), Segunda Turma, Relator Ministro João Otávio de Noronha, julgado em 16.3.2004, Diário de Justiça da União de 14.6.2004.

Superior Tribunal de Justiça. Recurso Especial n. 979.292/PB, Primeira Turma, Relator Ministro Teori Albino ZAVASCKI, julgado em 13.11.2007, Diário de Justiça da União de 3.12.2007, p. 302.

. Superior Tribunal de Justiça. Recurso Especial n. 1.100.057/RS (2008/0236004-2), Primeira Turma, Relator Ministro Benedito Gonçalves, julgado em 19.5.2009. Diário da Justiça Eletrônico de 7.6.2009.

Superior Tribunal de Justiça. Recurso Especial n. 476.342 - MT (2002/0108264-2), Primeira Turma, Relator Ministro Benedito Gonçalves, julgado em 06.08.2009, Diário da Justiça Eletrônico de 19.8.2009. 
- Superior Tribunal de Justiça. Recurso Especial n. 1.009.520/SP (2007/0279121-0), Primeira Turma, Relator Ministro Luiz Fux, julgado em 18.5.2010, Diário da Justiça Eletrônico de 25.6.2010.

- Superior Tribunal de Justiça. Recurso Especial n. 1.123.343/RS (2009/0027242-2), Segunda Turma, Relator Ministro Castro Meira, julgado em 8.6.2010, Diário da Justiça Eletrônico de 15.10.2010.

Superior Tribunal de Justiça. Súmula n. 5. Interpretação de Cláusula Recurso Especial: A simples interpretação de cláusula contratual não enseja recurso especial. 10.5.1990, Diário de Justiça da União de 21.5.1990).

Tribunal Regional Federal. Região, 2. Agravo de Instrumento n. 159.351/RJ, Sétima Turma Especializada, Relator Desembargador Reis Friede, julgado em 2.7.2008, Diário Eletrônico da Justiça Federal de 9.7.2008, p. 115.

Tribunal Regional Federal. Região, 4. Apelação Civil n. 48.806/RS, Terceira Turma, Relator Desembargador Maria Lúcia Luz Leiria, julgado em 30.03.2010, Diário Eletrônico da Justiça Federal de 28.4.2010.

. Tribunal Regional Federal. Região, 5. Apelação Civil n. 457.088/PE (2006.83.00.012127-9), Quarta Turma, Relator Desembargador Marcelo Navarro, julgado em 17.3.2009. Diário Eletrônico da Justiça Federal de 3.4.2010, p. 138.

Tribunal Regional Federal. Região, 5. Apelação Civil n. 451.548/PE (0010491-41.2008.4.08.8300), Primeira Turma, Relator Desembargador Rogério Fialho Moreira, julgado em 15.4.2010, Diário Eletrônico da Justiça Federal de 23.4.2010, p. 138.

BRUNA, Sérgio Varella. Agências reguladoras: poder normativo, consulta pública e revisão judicial. São Paulo: Revista dos Tribunais, 2003.

BUENO, Cassio Scarpinella. Amicus Curiae: Uma homenagem a Athos Gusmão Carneiro. In: DIDIER JR., F.; CERQUEIRA; L. O.; WAMBIER, T. A. A.. (Coord.) 0 Terceiro no Processo Civil Brasileiro e Assuntos Correlatos. Estudos em homenagem ao Professor Athos Gusmão Carneiro. Revista dos Tribunais, 2010.

CALIL, Lais. O poder normativo das agências reguladoras em face dos princípios da legalidade e da separação dos poderes. In: BINENBOJM, Gustavo. Agências Reguladoras e Democracia. Rio de Janeiro: Lumen Juris, 2006, p. 111-176.

CANOTILHO, José Joaquim Gomes. Direito constitucional e teoria da constituição. 3. ed.. Coimbra: Almedina, 1999.

CANOTILHO, José Joaquim Gomes; MOREIRA, Vital. Constituição da República Portuguesa anotada. Vol. I. 4a․ Coimbra: Coimbra, 2007

CÂMARA, Alexandre Freitas. Lições de Direito Processual Civil. Vol. I. 9ạ ed. Rio de Janeiro: Lumen Juris, 2004. 
CARVALHO, Raquel Melo Urbano. Curso de Direito Administrativo. Salvador: Podivm, 2008.

CUÉLLAR, Leila. Introdução às Agências Reguladoras Brasileiras. Belo Horizonte: Fórum, 2008.

CYRINO, André Rodrigues. Separação de poderes, regulação e controle judicial: por um amicus curiae regulatório. Revista Brasileira de Direito Público - RBDP, Belo Horizonte: Fórum, v. 5, n. 19, p. 67-95, out.-dez. 2007.

DAROCA, Eva Desdentado. Los Problemas del Control Judicial de la Discrecionalidad Técnica. Madrid: Civitas, 1997.

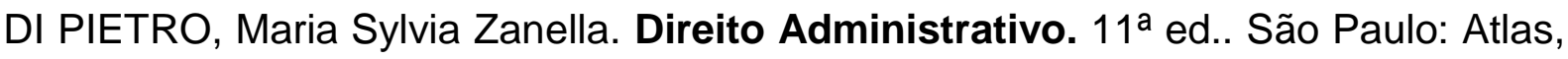
1999.

Parcerias na administração pública: concessão, permissão, franquia, terceirização e outras formas. $4^{a}$ ed. São Paulo: Atlas, 2002.

Limites da função reguladora das agências diante do princípio da

legalidade. In

Fórum, 2003, p. 27 a 60.

. Direito Regulatório, Temas Polêmicos. Belo Horizonte:

. Discricionariedade técnica e discricionariedade administrativa. In: FIGUEIREDO, Marcelo; PONTES, Valmir. (Org.). Estudos de direito público. São Paulo: Malheiros, 2006, v. 1, p. 480-504.

Discricionariedade Administrativa na Constituição de 1988. $2^{\mathrm{a}}$ ed.. São Paulo: Atlas, 2007.

ENTERRÍA; Eduardo García de; FERNÁNDEZ, Tomás-Ramón. Curso de Derecho Administrativo . Vol. 1. 10 ed.. Madrid: Civitas, 2000.

FAGUNDES, Miguel Seabra. O Controle dos Atos Administrativos pelo Poder Judiciário. $7^{\underline{a}}$ ed.. Rio de Janeiro: Forense, 2006.

FARIA, José Eduardo. Antinomias jurídicas e gestão econômica. Lua Nova: Revista de Cultura e Política, Ética Política e Gestão Econômica, n. 25, p. 167-173. 1992.

FERRAZ JÚNIOR, Tércio Sampaio. Como regular agências reguladoras? Revista Brasileira de Direito Público (RBDP). Belo Horizonte: Fórum, ano 6, n. 22, p. 7-24, jul.-set. 2008.

GOMES, Joaquim B. Barbosa. Agências Reguladoras: A "Metamorfose" do Estado e da Democracia. In: BINENBOJM, Gustavo (Coord.). Agências Reguladoras e Democracia. Lumen Juris: Rio de Janeiro, 2006, p. 21-57.

GUERRA, Sérgio. Discricionariedade Técnica e Agências Reguladoras in Anais do Seminário As Agências Reguladoras. In: SEMINÁRIO AS AGÊNCIAS 
REGULADORAS, Mata de São João - BA, Anais... ESMAF - Escola de Magistratura da 1를 Região. 2004, p. 9-21.

2005.

. Controle judicial dos atos regulatórios. Rio de Janeiro: Lumen luris,

Atualidades sobre o controle judicial dos atos regulatórios. Revista Eletrônica de Direito Administrativo Econômico (REDAE), Salvador, v. 21, p. 124, fev.-abr. 2010. Disponível em: <http://www.direitodoestado.com/revista/REDAE21-FEVEREIRO-2010-SERGIO-GUERRA.pdf>. Acesso em: 27 nov. 2011.

GRAU, Eros Roberto. 0 direito posto e o direito pressuposto. 3. ed. São Paulo: Malheiros, 2000.

JUST, Gustavo. O princípio da legalidade administrativa: o problema da interpretação e os ideais do direito público. In: ADEODATO, João Maurício; BRANDÃO, Cláudio; CAVALCANTI, Francisco (Coords.). Princípio da legalidade: Da Dogmática Jurídica à Teoria do Direito. Rio de Janeiro: Forense, 2009, p.236.

JUSTEN FILHO, Marçal. O Direito das Agências Reguladoras Independentes. São Paulo: Dialética, 2002.

. Curso de direito administrativo. São Paulo: Saraiva, 2005.

Agências Reguladoras e Democracia: Existe um Déficit Democrático na 'Regulação Independente'?. In: ARAGÃO, Alexandre Santos (Coord.). O Poder Normativo das Agências Reguladoras. Rio de Janeiro: Forense, 2006, p. 301-332.

HIPOLLITO, Lúcia. Palestra de abertura do Painel I: Evolução e eficácia de controle. Controle interno, externo e social. In: SEMINÁRIO INTERNACIONAL: QUEM CONTROLA AS AGÊNCIAS REGULADORAS DE SERVIÇOS PÚBLICOS? Brasília, 2001. Anais... Brasília: Instituto Helio Beltrão, 2003, p. 17-19.

LA SPINA, Antonio; MAJONE, Giandomenico. Lo Stato regolatore. Bologna: II Mulino, 2000.

LOUREIRO, Caio de Souza. A intervenção processual do órgão regulador. Revista de Direito Público da Economia, v. 27, p. 221-247, 2009.

MAJONE, Giandomenico. Do Estado Positivo ao Estado Regulador: causas e conseqüências da mudança no modo de governança. In: MATTOS, Paulo Todescan Lessa. Regulação Econômica e Democracia: O Debate Europeu. São Paulo: Editora Singular, 2006.

MARQUES, Maria Manuel Leitão; MOREIRA, Vital. Desintervenção do Estado, privatização e regulação dos serviços públicos. Economia e Perspectiva. In: MOURA, Joaquim Pina. O Estado, a economia e as empresas. Lisboa, v. 3, n. 2, p. 133-158, 1988/1999. 
MARQUES NETO, Floriano Azevedo. A Nova Regulação Estatal e as Agências Independentes. In: SUNDFELD, Carlos Ari (Coord.) Direito Administrativo Econômico. 2000, p. 72-98

Editores, 2002.

Regulação Estatal e Interesses Públicos. São Paulo: Malheiros Agências Reguladoras: Instrumentos de fortalecimento do Estado. São Paulo: Associação Brasileira de Regulação (ABAR), 2003.

Agências Reguladoras Independentes. Belo Horizonte: Fórum, 2005.

MAS, Joaquín Tornos. Las Autoridades de Regulácion de lo Audiovisual. Madrid: Martins Pons, 1999.

MATTOS, Paulo Todescan Lessa, Regulação Econômica e Democracia: contexto e perspectivas na compreensão das agências de regulação no Brasil, in Regulação, Direito e Democracia, José Eduardo Faria (Org.), pp. 43-66. São Paulo: Editora Fundação Perseu Abramo, 2002.

Autonomia Decisória, Discricionariedade Administrativa e Legitimidade da Função Reguladora do Estado no Debate Jurídico Brasileiro. In: ARAGÃO, Alexandre Santos (Coord.). O Poder Normativo das Agências Reguladoras. Rio de Janeiro: Forense, 2006, p. 333-364.

MEIRELLES, Hely Lopes. Direito administrativo brasileiro, 22. ed.. São Paulo: Malheiros, 1997.

MELLO, Celso Antônio Bandeira de. Curso de Direito Administrativo. 25ํㅡㄹ. ed.. São Paulo: Malheiros Editores, 2008.

MELO, Marcus André. A Política da Ação Regulatória: Responsabilização, Credibilidade e Delegação. Revista Brasileira de Ciências Sociais, n. 46, jun., 2001, p. 64.

MENDES, Conrado Hübner. Reforma do Estado e Agências Reguladoras: Estabelecendo os Parâmetros de Discussão. In: SUNDFELD, Carlos Ari (Org.). Direito Administrativo Econômico. São Paulo: Malheiros Editores, 2000, p. 130131.

MENDES, Gilmar Ferreira. Controle de Constitucionalidade dos Atos Normativos das Agências. In: SEMINÁRIO AS AGÊNCIAS REGULADORAS, Mata de São João BA, Anais... ESMAF - Escola de Magistratura da 1ª Região. 2004, p. 109-126.

MORAES, Germana de Oliveira. Controle jurisdicional da Administração Pública. São Paulo: Dialética, 1999.

MOREIRA, Egon Bockmann. Agências Reguladoras Independentes, Déficit Democrático e a "Elaboração Processual de Normas". In: CUÉLLAR, Leila; 
MOREIRA, Egon Bockmanm. Estudos de Direito Econômico. Belo Horizonte: Fórum, 2004, p. 161-206.

Os Limites à Competência Normativa das Agências Reguladoras. ARAGÃO, Alexandre dos Santos (Coord.). O Poder Normativo das Agências Reguladoras. Rio de Janeiro: Forense, 2006.

MOREIRA, Vital. Auto-Regulação Profissional e Administração Pública. Coimbra: Almedina, 1997a.

Administração Autônoma e Associações Públicas. Coimbra: Coimbra Editora, 1997b.

MOREIRA, Vital; MAÇÃS, Fernanda. Autoridades Administrativas Independentes - Estudo e Projecto de Lei-Quadro. Coimbra: Coimbra, 2003.

MORÓN, Miguel Sanches. Discrecionalidad administrativa y control judicial. Madrid: Tecnos, 1994.

OLIVEIRA, Vallisney de Souza. Constituição e Processo Civil. Editora Saraiva: São Paulo, 2008.

ORTIZ, Gaspar Ariño. Principios de derecho público económico: modelo de Estado, gestión pública, regulación económica. Granada: Comares, 2004.

. Sucessos e Fracassos da regulação. Revista Eletrônica de Direito Administrativo Econômico. Salvador, Instituto de Direito Público da Bahia, n.3, ago.-set. 2005. Disponível em: <http://www.direitodoestado.com.br/redae.asp>. Acesso em: 27 nov. 2011.

OTERO, Paulo. Legalidade e Administração Pública: o Sentido da Vinculação Administrativa à Juridicidade. Coimbra: Almedina, 2003.

PARENTE, Pedro. Palestra de abertura do SEMINÁRIO INTERNACIONAL: QUEM CONTROLA AS AGÊNCIAS REGULADORAS DE SERVIÇOS PÚBLICOS? Brasília, 2001. Anais... Brasília: Instituto Helio Beltrão, 2003, p. 10-16.

PEREIRA, Cesar A. Guimarães. Discricionariedade e Apreciações Técnicas da Administração. Revista de Direito Administrativo, Rio de Janeiro, n. 231, jan.-mar. 2003, p. 254-261.

PEREIRA, Renée. Criadas para intermediar problemas, agências são questionadas na Justiça. O Estado de S. Paulo. São Paulo, 25 jul., 2011.

RAMALHO, Pedro Ivo Sebba. Regulação e agências reguladoras: reforma regulatória da década de 1990 e desenho institucional das agências no Brasil. In: Regulação e Agências Reguladoras Governança e Análise de Impacto Regulatório. Brasília: Anvisa, 2009. 
SHAPIRO, Martin. Who guards the guardians?: judicial control of administration. Atlanta:University of Georgia, 1988.

SILVA, José Afonso da. Curso de direito constitucional positivo. 23. ed. São Paulo: Malheiros, 2004.

SOUTO, Marcos Juruena Villela. Direito Administrativo Regulatório. Rio de Janeiro: Lumen Juris, 2002.

SUNDFELD, Carlos Ari; CÂMARA, Jacintho Arruda. O Poder Normativo das Agências em Matéria Tarifária e a Legalidade: o Caso da Assinatura do Serviço Telefônico. In: ARAGÃO, Alexandre Santos (Coord.). O Poder Normativo das Agências Reguladoras. Rio de Janeiro: Forense, 2006, p. 605-636.

UNIVERSIDADE de São Paulo. Inter-relações entre o processo administrativo e - Judicial sob a perspectiva da segurança jurídica no plano da concorrência econômica e da eficácia da regulação pública. Disponível em: $<$ http://www.cnj.jus.br/images/pesquisasjudiciarias/Publicacoes/relat_pesquisa_usp_ edital1_2009.pdf>. Acesso em: 27 nov. 2011

VERISSIMO, Marcos Paulo. Controle Judicial da Atividade Normativa. In: ARAGÃO, Alexandre Santos (Coord.). O Poder Normativo das Agências Reguladoras. Rio de Janeiro: Forense, 2006, p. 377-418.

WIMMER, Miriam. Discricionariedade administrativa, conceitos jurídicos indeterminados e controle judicial: limites e possibilidades. Revista de Direito de Informática e Telecomunicações (RDIT), Belo Horizonte, ano 3, n. 5, jul.dez. 2008. Disponível em: <http://bdjur.stj.jus.br/dspace/handle/2011/28637>. Acesso em: 27 nov. 2011. 


\section{ANEXO A}

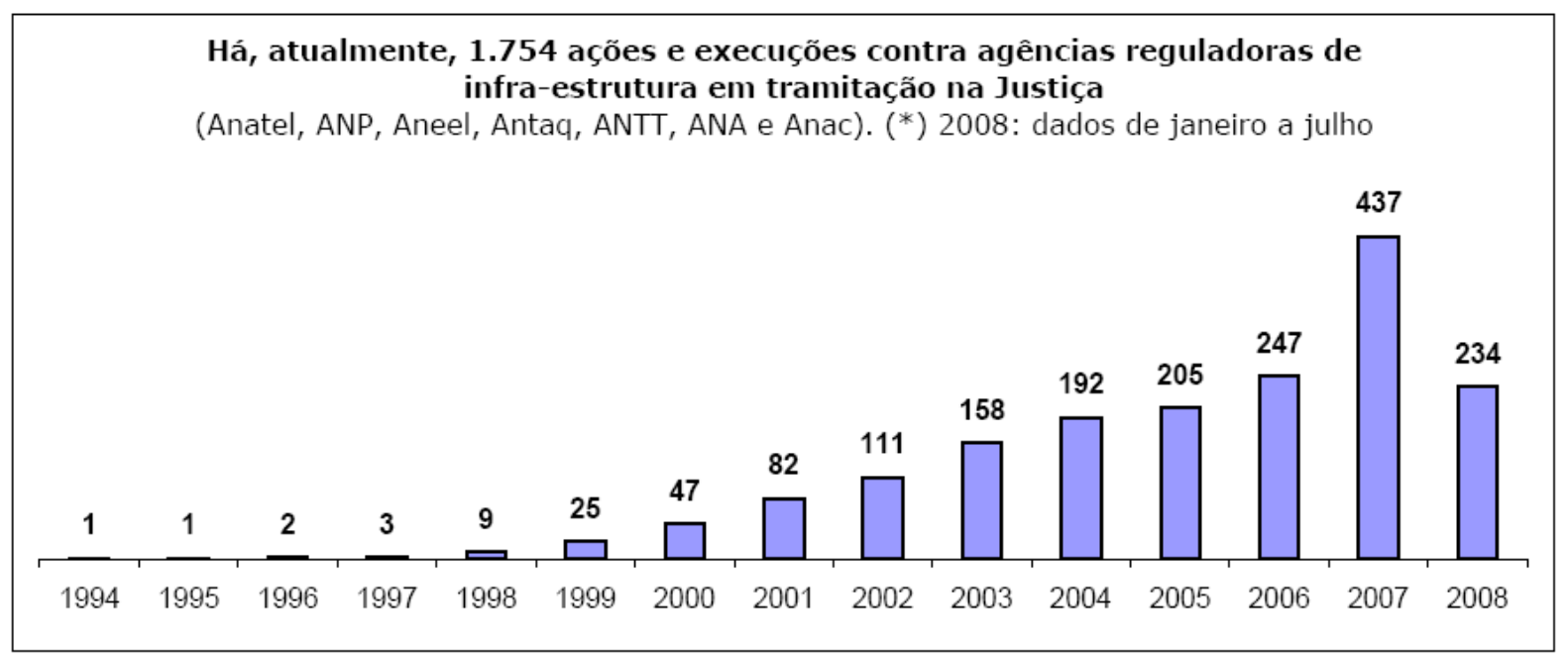




\section{ANEXO B}

Total de processos judiciais em levantamento preliminar

\begin{tabular}{|c|c|c|c|c|c|c|}
\hline & $1^{\mathbf{a}}$ Região & $2^{\mathbf{a}}$ Região & $3^{\mathbf{a}}$ Região & $4^{\mathbf{a}}$ Região & $5^{\text {a }}$ Região & Total \\
\hline ANA & 135 & 6 & 11 & 5 & 9 & 166 \\
\hline ANAC & 336 & 30 & 102 & 0 & 24 & 492 \\
\hline ANATEL & 21543 & 143 & 3549 & 1171 & 4827 & 31233 \\
\hline ANCINE & 35 & 31 & 3 & 1 & 0 & 70 \\
\hline ANEEL & 4690 & 44 & 1160 & 345 & 319 & 6558 \\
\hline ANP & 5534 & 112 & 3072 & 51 & 2253 & 11022 \\
\hline ANS & 1237 & 52 & 1537 & 180 & 446 & 3452 \\
\hline ANTAQ & 247 & 35 & 10 & 9 & 8 & 309 \\
\hline ANTT & 2671 & 62 & 518 & 54 & 196 & 3501 \\
\hline ANVISA & 2848 & 48 & 769 & 31 & 424 & 4120 \\
\hline CADE & 1293 & 45 & 263 & 6 & 33 & 1640 \\
\hline CVM & 8729 & 900 & 4463 & 150 & 7894 & 22136 \\
\hline Previc & 1 & 6 & 0 & 0 & 0 & 7 \\
\hline Total & 49299 & 1514 & 15457 & 2003 & 16433 & $\mathbf{8 4 7 0 6}$ \\
\hline
\end{tabular}

Fonte: Dados da pesquisa 


\section{ANEXO C - Transitados em Julgado por Tipo de Desfecho}

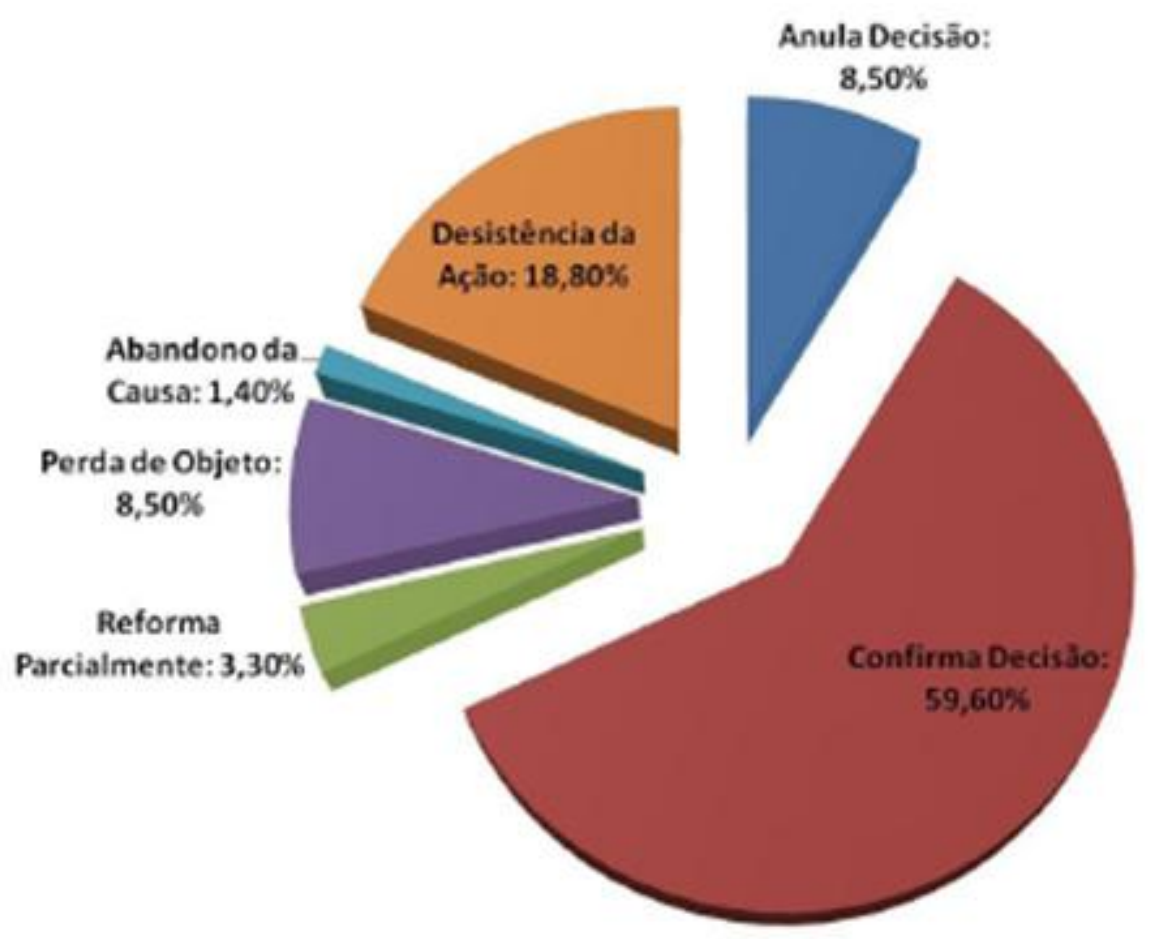

Fonte: Pesquisa de Campo realizada pela USP (2011) 
ANEXO D - Taxa de Confirmação de Transitados em Julgado com Julgamento de Mérito

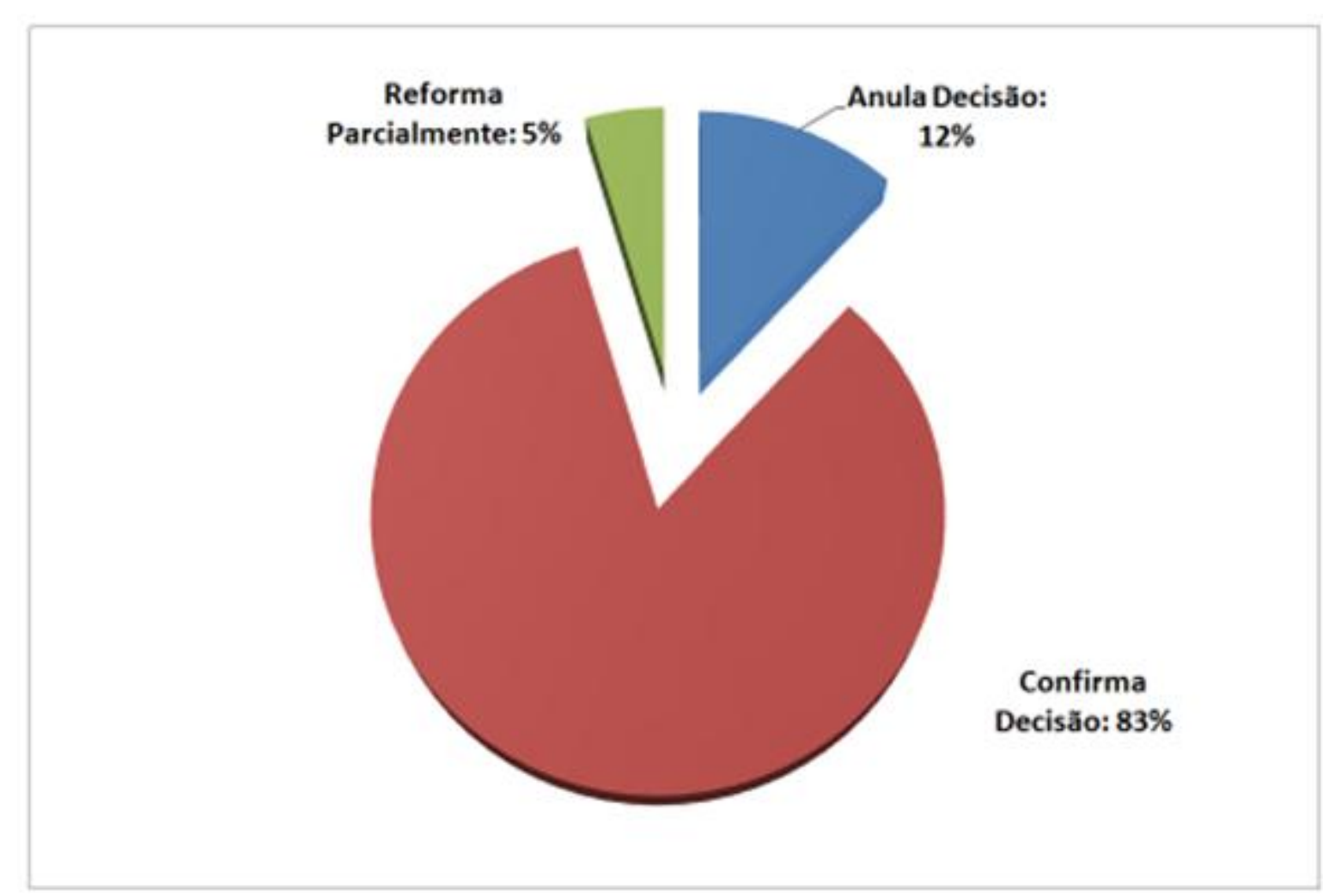

Fonte: Pesquisa de Campo realizada pela USP (2011) 


\section{ANEXO E - Duração Média de Casos Transitados em Julgado}

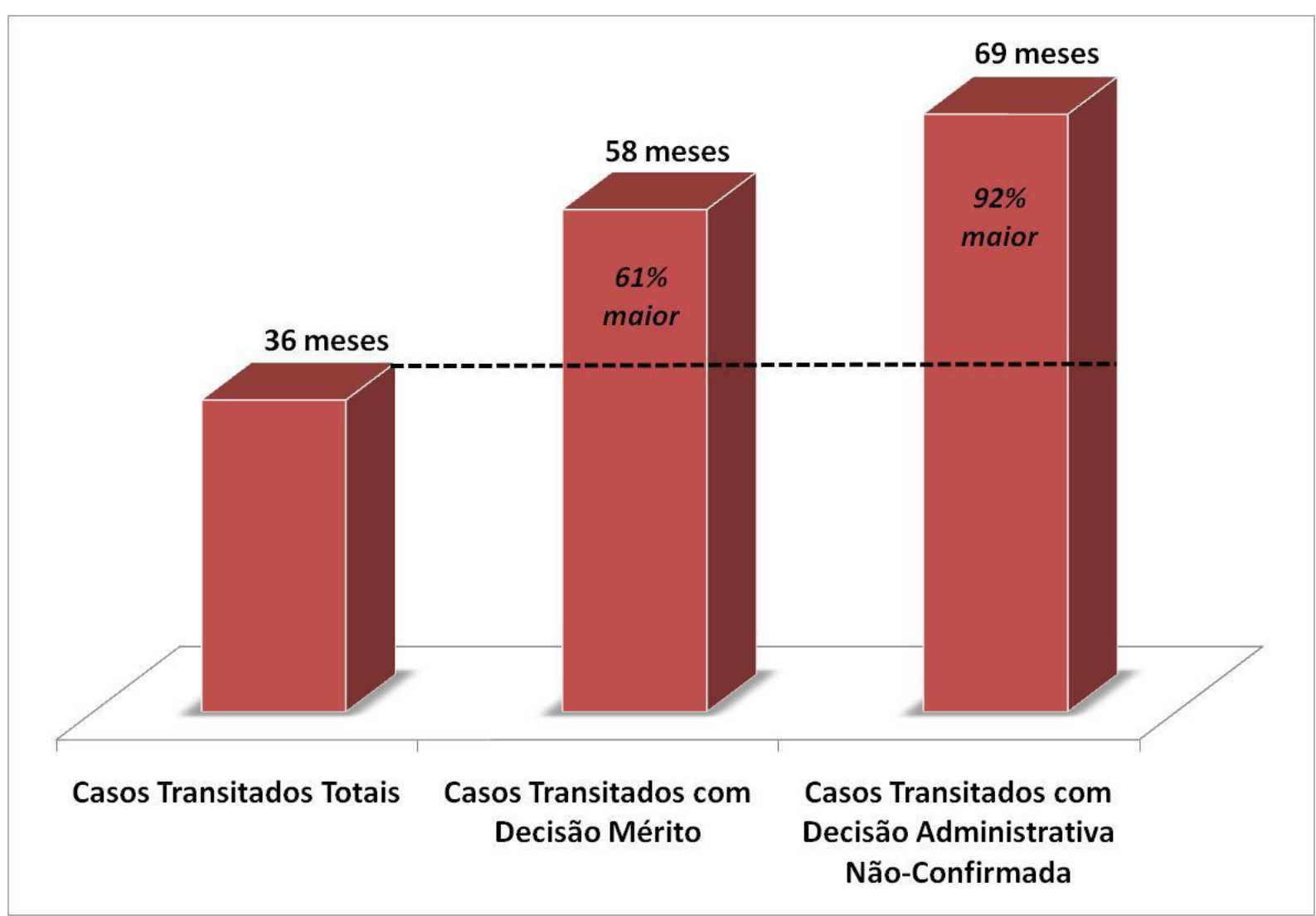

Fonte: Pesquisa de Campo realizada pela USP (2011) 
ANEXO F - Viés de Seleção em Transitados em Julgado

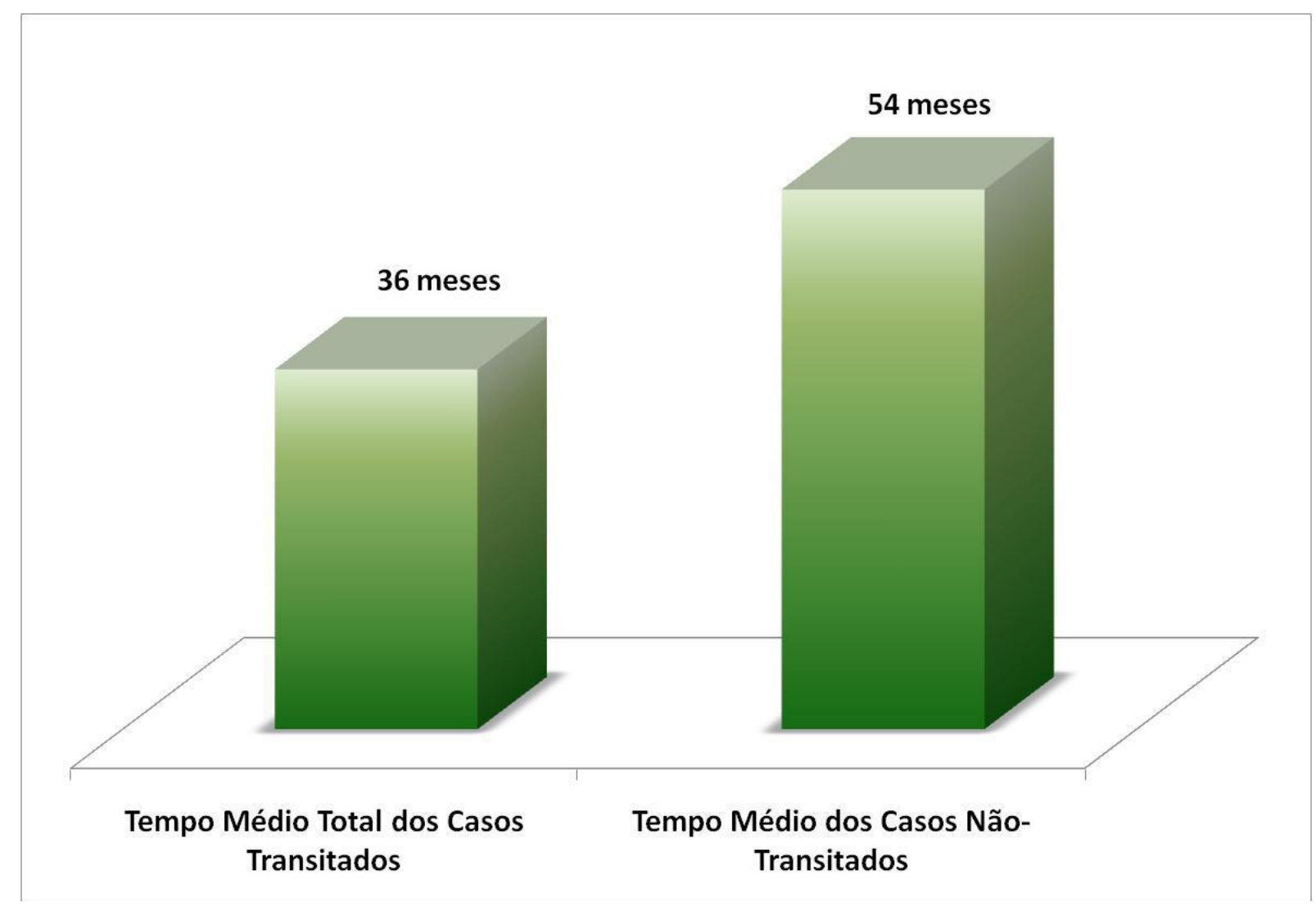

Fonte: Pesquisa de Campo realizada pela USP (2011) 
ANEXO G - Taxa de Anulação da Decisão Administrativa em 1a Instância e em Transitados em Julgado

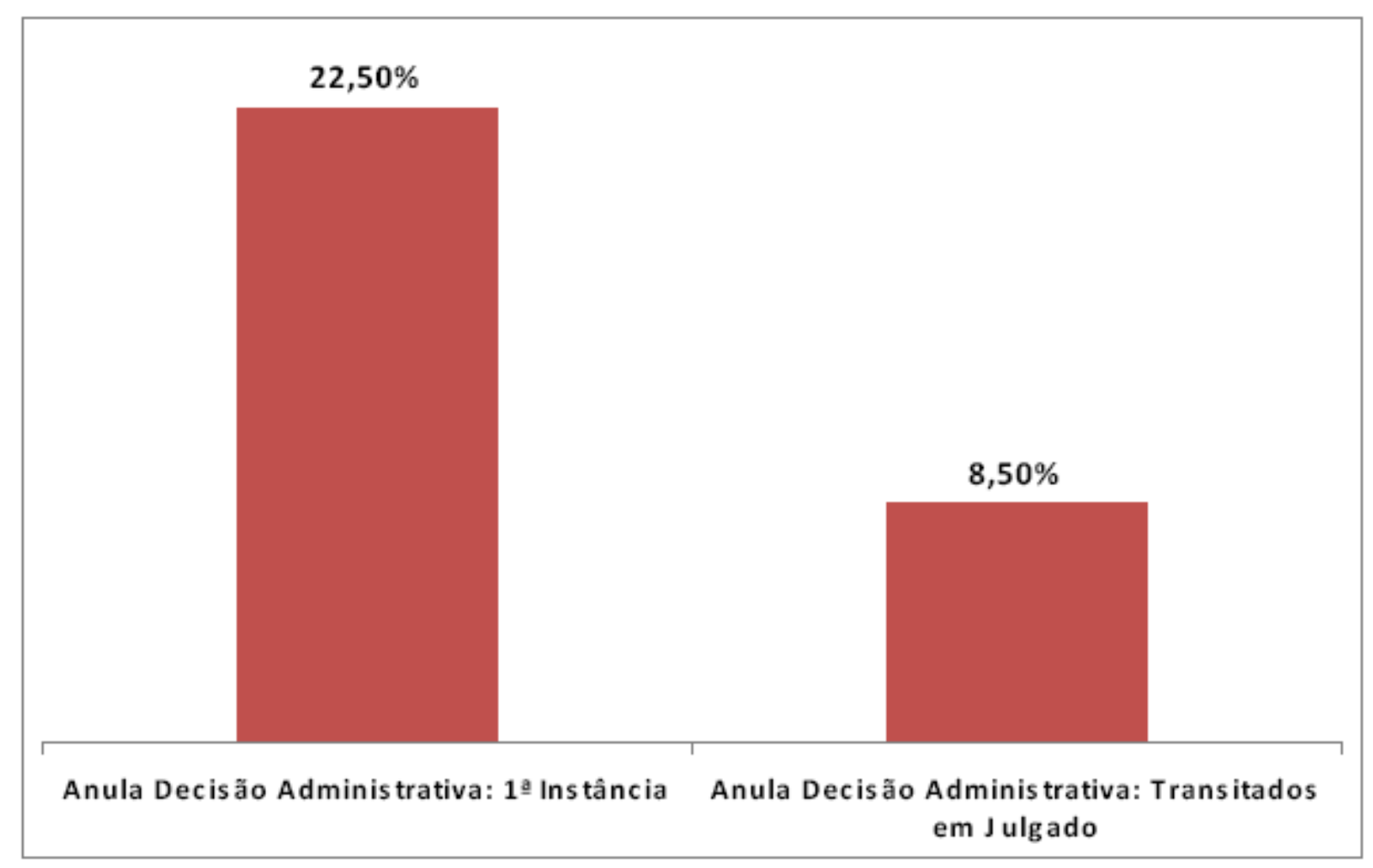

Fonte: Pesquisa de Campo realizada pela USP (2011) 
ANEXO H - Taxa de Confirmação da Decisão Administrativa em 1ª Instância e em Transitados em Julgado: apenas decisões de mérito

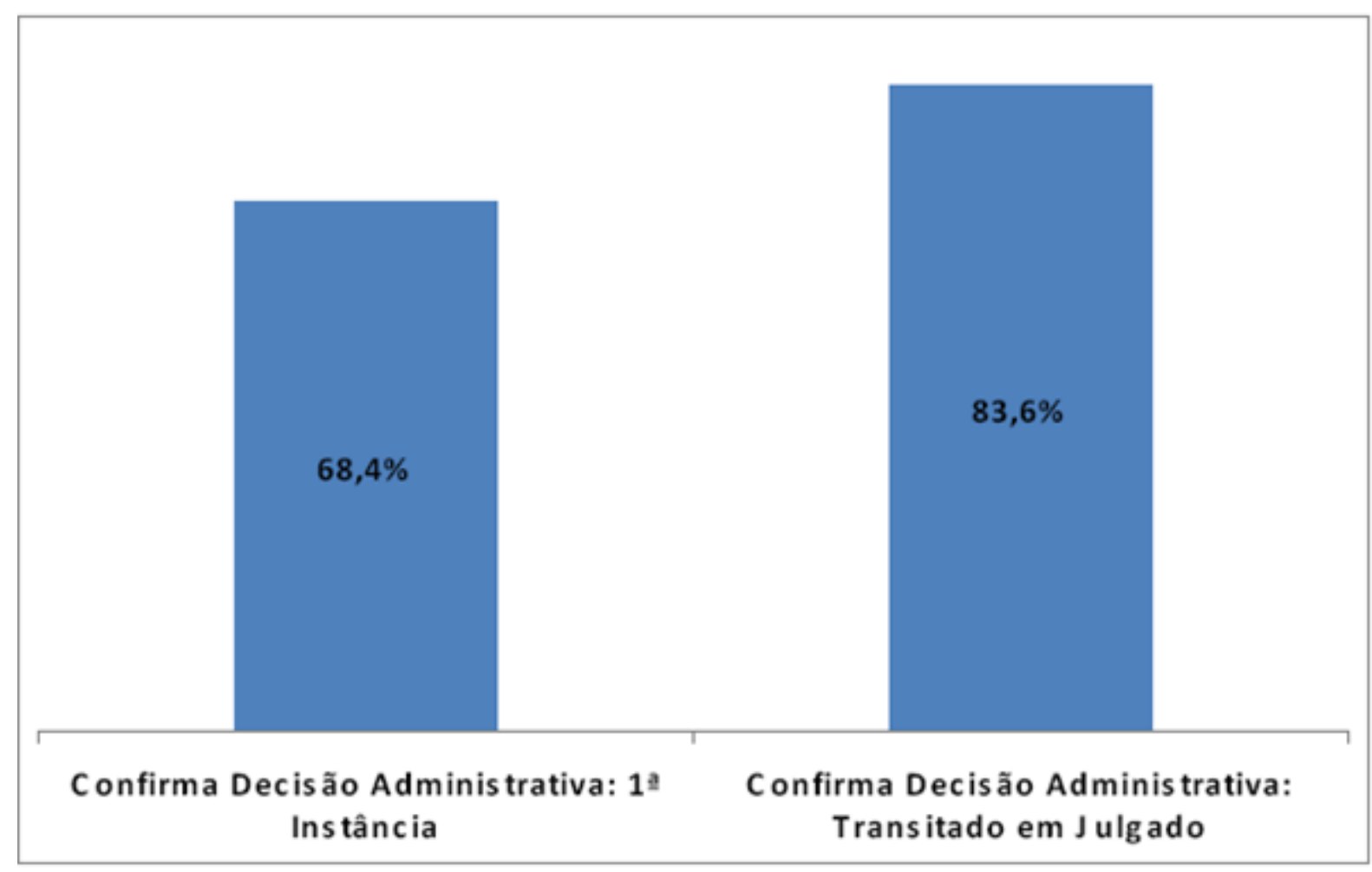

Fonte: Pesquisa de Campo realizada pela USP (2011) 